STATE OF ILLINOIS

DEPARTMENT OF REGISTRATION AND EDUCATION

DIVISION OF THE

NATURAL HISTORY SURVEY

THEODORE H. FRISON, Acting Chief

Vol. XIX. BULLETIN Article I.

\title{
The Fishes of Champaign County
}

A Study of the Distribution and Abundance of Fishes in Small Streams

BY

DAVID H. THOMPSON

and

FRANCIS D. HUNT

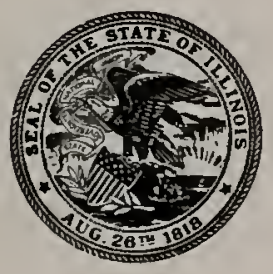

PRINTED BY AUTHORITY OF THE STATE OF ILLINOIS

URBANA, ILLINOIS

SEPTEMBER, 1930 


\section{STATE OF ILLINOIS \\ DEPARTMENT OF REGISTRATION AND EDLCATION \\ M. F. WALsh, Director}

BOARD OF NATURAL RESOURCES AND CONSERIATION

M. F. Walsh, Chairman

William Trelease, Biology

Hexry C. Cowles, Forestry

EDsox S. Bastix, Geology

William A. Noyes, Chemislry
Johx II: Alrord, Enginecring

Charles M. Thosipsox. Representing the Prosident of the Cnizersity of Illinnis

\section{STATE NATURAL HISTORY SURIEY DIYISION \\ TuEonore H. Frisox, Aiting Chicf}

H. C. Oesterlixg, Editor

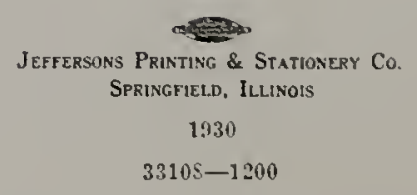




\section{TABLE OF CONTENTS}

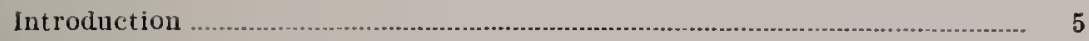

Description of the area .................................................................................. 5

Description of the streams....................................................... 7

Methods and equipment........................................................................... 14

List of species, with analytical keys and data on distribution and

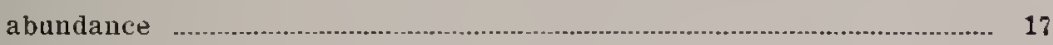

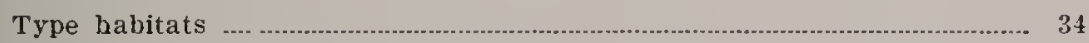

Abundance and number of kinds.................................................................... 39

Relation of distribution and abundance to stream size $\ldots \ldots \ldots \ldots \ldots \ldots \ldots . . . . \quad 41$

Headwater fishes ............................................................................................ 47

Relation of soil fertility to growth and abundance of fisbes _...-............ 48

Effects of pollution on growth, distribution, and abundance of fishes...... 50

Other environmental factors affecting distribution and abundance........... 58

Effect of fish-eating species on abundance............................................ 58

Some observations on morphological adaptations...................................... $5 \mathrm{~s}$

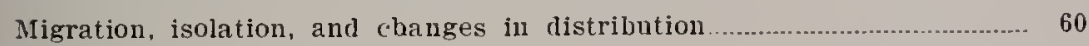

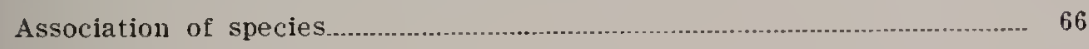

Summary _.___

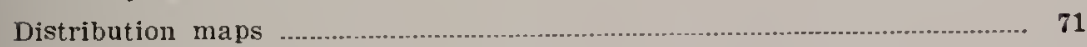

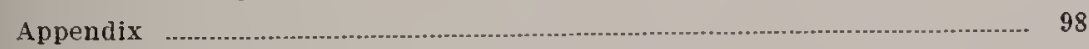

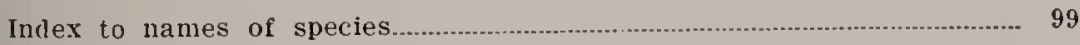





\section{THE FISHES OF CHAMPAIGN COUNTY * \\ A Study of the Distribution and Abundance of Fishes in Small Streams}

\section{David H. Thompson and Francis D. Hunt}

A careful account of the local and general distribution of the fishes of Illinois, their relations to their environment, and the function and relative importance of each species in the general system of aquatic life, was presented twenty years ago in a comprehensive work by Forbes and Richardson ${ }^{1}$, which was based primarily on a state-wide ichthyological survey. In the present study the general methods employed in the former survey have been applied intensively to a small area. Champaign County, and use has been made of special methods which yield results more strictly quantitative. Inasmuch as there exist among the small stream systems of this county famal differences comparahle to those found among large stream systems, not only in Illinois but elsewhere as well, the intensive study of this restricted area has made it possible to formulate in a more precise manner some of the general conclusions previously reached by other workers on the distribution and abundance of fishes. The use of quantitative methods of collecting has made it possible also to arrive at new conclusions lased on such data as may have passed unnoticed in a less detailed study or in streams too large to apply such methods.

\section{Description of the Area}

Champaign Connty is located in the east-central part of Illinois and is crosserl by the 88 th meridian and the 40th parallel. Measuring approximately 36 miles from north to south and 27.5 miles from east to west, the county has an area of 988 square miles. The topography varies from flat to slightly rolling land, the variations heing due to two causesglacial action and stream erosion. The average altitude is about 710 feet above sea level: a maximum of 860 feet is reached on the Champaign moraine and a minimum of 630 feet where the Salt Fork leaves the county.

"This study was carried on and completed under the direction of the late Stephen Aifred Forhes.

1. Forhes, S. A., and R. E. Richardson. "The Fishes of Illinois." Final Reports of the Hilinois Natural History Survey, Vol. III, 1903. 
During the Glacial Period, Champaign County was covered by two ice sheets, the Illinoian and the Early Wisconsin; and the otherwise monotonous topography of the county is broken by their terminal moraines, which commonly rise 50 to 100 feet above the intermorainal tracts, vary from one-half mile to three or four miles in width, and usually form the boundaries between the several drainage basins (Fig. 1). As the Early Wisconsin sheet receded. the various parts of the county were uncovered in the following order: first, the lower part of the

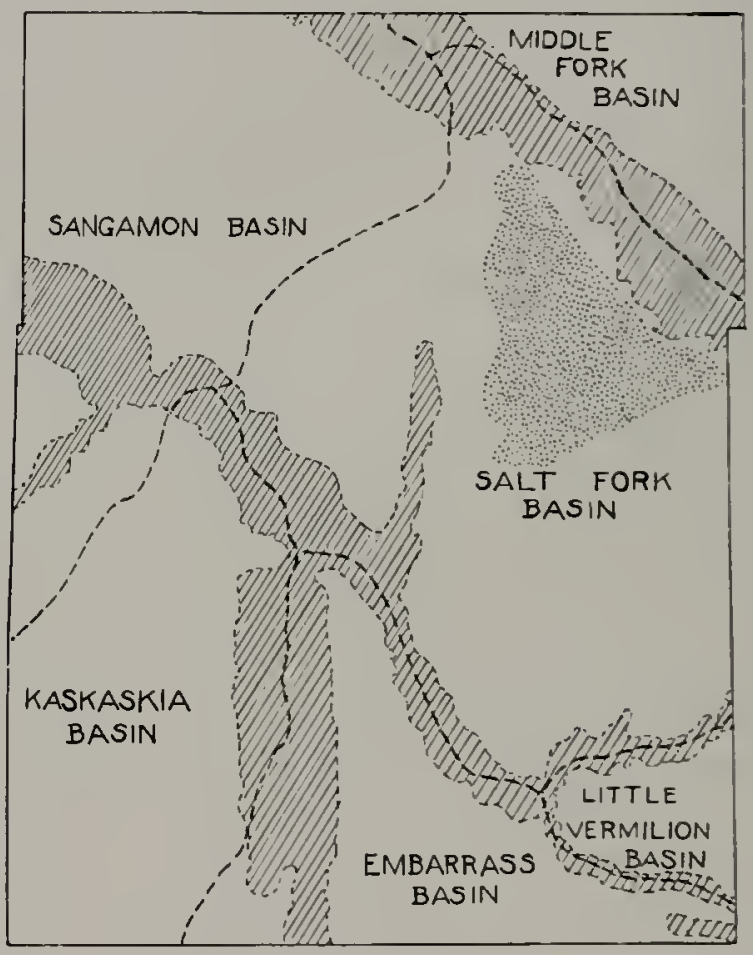

Fig. 1. Sketch map ni Chanpaign Couniy, showing watersheds (ciutted lines), glacial moraines (cross-hasching), and unusually fertile area (stippling).

Sangamon basin; next, the Faskaskia and Embarrass basins: then the upper Sangamon, Salt Fork, and Little V'ermilion hasins: and lastly, the basin of the Middle Fork of the Vermilion. The general aspects of the topography now are the same as at that time. and there has been no subsequent change in the hook-up of the drainage systems." There are no outcrops of rock in the county, as it is covered with a layer of boulder clay ranging from 95 to $300^{\circ}$ feet in thickness. ${ }^{3}$

2. Personal communication from Nr. M. M. Leighton, Chicf, Illinois state Geological Survey.

3. III, Agr. Exy, Sta, Soil Renolt No. 18, "Champisign County" Soits," 1918. 
The soils of Chanmaign Comnty are fertile and. taken as a whole, are more uniform than those of other counties of the state. Dark upland prairie soils make up 92 percent of the area of the county, and upland timber soils an arlditional 5 percent. Of the 92 percent of upland prairie soils, 73 is brown silt loam and 18 is black clay loam. Almost all of the upland timber soil is yellow-gray silt loam. The water-table in the county lies 45 to 60 inches beneath the surface and is generally more uniform in depth than in other counties. ${ }^{4}$

There is an area of about 50 square miles in the eastern part of the county in which the soil has a different history from that of the rest of the county and is unusually fertile. This area is drained by the East Branch of the Salt Fork and lies north of the town of St. Joseph. (See Figure 1.) The soil of this area was formed under water, and until this part of Illinois was settled, it was a marsh in which water-fowl abounded. Later, when ditches were dug, the marsh was reduced to a few ponds, and more recently it has been drained completely. but the organic matter that had accumulated under water has not leacherl away. The soil is highly calcareous and therefore rich in availal,le plant foods; nodules of calcium carbonate occur throughout it and render it more alkaline than other soils of the county. An unusually rich fish fauna was found in the streams of this area, as will be shown in a later section.

Weather records for the past 26 years have been kept by an observer of the United States WVather Bureau at Urbana. The WVeather Bureau station is near the center of the county and has an altitude of 743 feet. The mean annual temperature for the 26 years is $51.2^{\circ} \mathrm{F}$. and the mean annual rainfall 34.26 inches. The mean temperature for 1928 alone was $51.4^{\circ} \mathrm{F}$. and the total rainfall 32.96 inches.

The mean monthly temperatures for 1928 and for the past 26 years are as follows:

$\begin{array}{lllllllllllll} & \text { Jan. } & \text { Feb. Mar. Apr. Nay Jume July } & \text { Aug. Sept. Oct. Nor. Dec. } \\ 1928 & 27.5 & 32.2 & 39.6 & 46.8 & 61.8 & 65.4 & 74.8 & 74.0 & 61.8 & 57.2 & 42.4 & 33.4 \\ \text { Are. 26 yrs. } & 25.9 & 27.7 & 40.2 & 50.4 & 61.0 & 70.3 & 74.7 & 72.9 & 66.2 & 54.1 & 41.7 & 29.3\end{array}$

The mean monthly rainfalls for 1928 and for the past 26 vears are as follows:

Jan. Feb. Mar. Apr. May June July Aug. Sept. Oct. Nov. Dec.

$\begin{array}{lllllllllllll}1928 & 2.18 & 2.28 & 1.45 & 3.16 & 2.48 & 4.65 & 3.59 & 2.77 & 3.65 & 2.34 & 1.88 & 2.53\end{array}$

$\begin{array}{lllllllllllll}\text { Ave. 26 yrs. } & 2.12 & 1.78 & 3.38 & 3.7+ & 3.94 & 3.16 & 3.01 & 3.44 & 2.98 & 2.38 & 2.13 & 2.20\end{array}$

\section{Description OF tile StrEanis}

Six streams have their headwaters in Chanpaign County: the Sangamon River, the Salt Fork and the Middle Fork of the Vermilion River, the Embarrass (pronouncerl Amloraw), the Kaskaskia (otherwise known as the Okaw), and the little Vermilion. The headwaters of

4. Personal communication from Mr. L. A. Norton, Assistant Chief, Soil Survey. 
these six streams interlace except as they are separated by glacial moraines (see Figure 1). The drainage area in square miles at the point where each stream leaves the county is as follows: Sangamon 388, Salt Fork 307, Micldle Fork 241, Embarrass 106, Kaskaskia 98, and Little

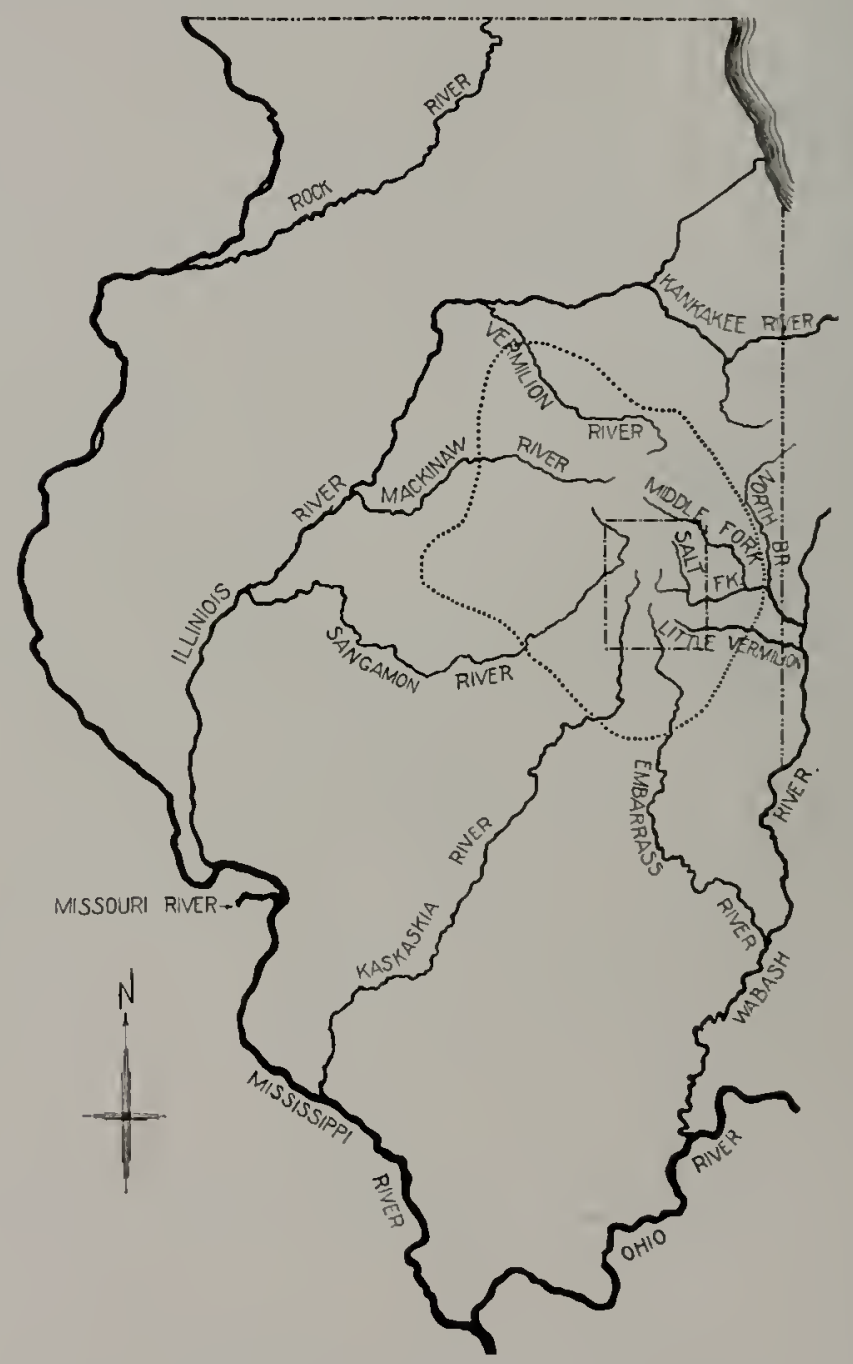

Fig. 2. Sketch map of lllinois, showing the location of Champaign County with respect to stream systems. The dotted line indicates the houndary of the unusually fertile area discussed in the lext (page 50 ).

Vermilion 28. Other small streams flow out of the countr, but they soon join one or the other of these six larger ones. The relation of these headwater streams to the larger streans of Illinois is shown in Figure 2. 
While fishes in the headwaters of the Salt Fork may be but 2 or 3 miles overland from fishes in the headwaters of the Sangamon, they are more than 1,200 miles apart by water.

Because of the essential flatness of the county, most of the smaller streams have been straightened and deepened by dredging. This dredging has tended toward greater unifornity of environment but has not changed appreciably the kinds of fishes present nor their general distribution within the streams. However, dredging lias an effect on the minutiae of their distribution and. less obviously, on their abundance. The cycle of change may be summed up as follows:

A brook meanders across a pasture with alternate gravelly riffles and vegetation-bordered stretches of numd and sand; is slowed down as it enters pools about the roots of trees in a patch of woodland; or is

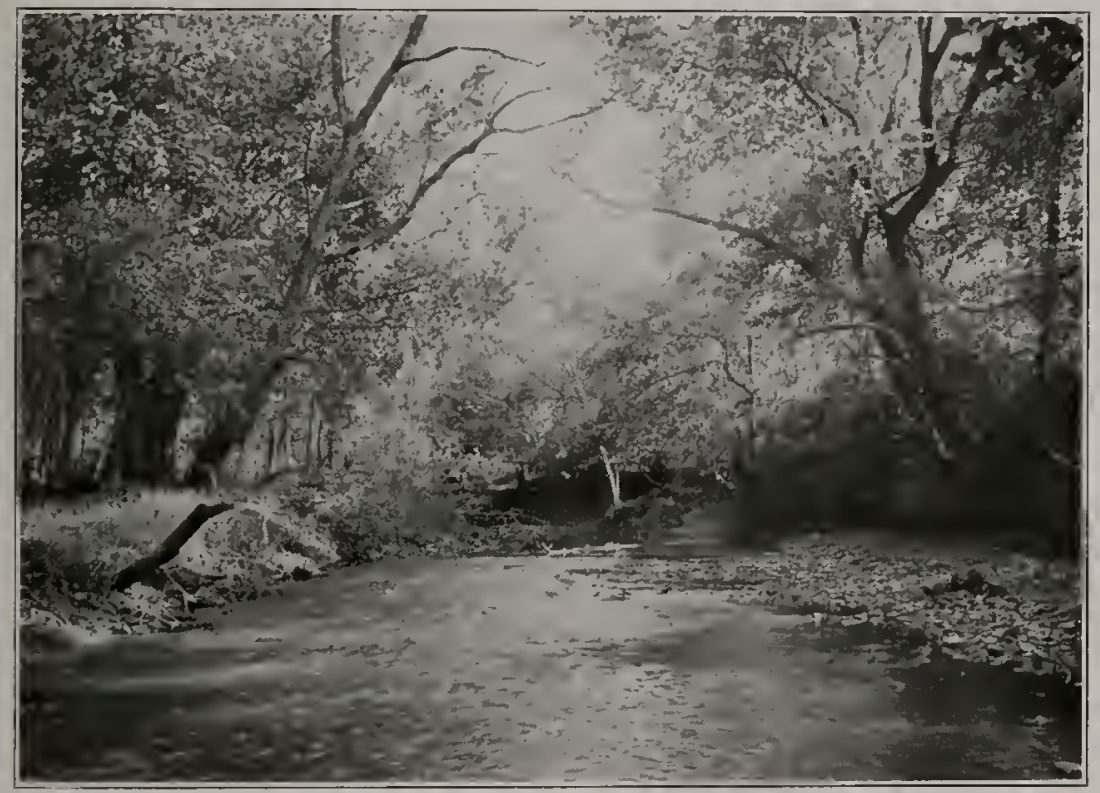

Fig. 3. V View of Sanganon River near Mahomet.

scattered into a dozen channels as it passes through a bit of marsh choked with willows and cat-tails. Thus the stream is well differentiated into a variety of situations, each with its own characteristic fishes. A dredging machine goes past and we have, instead, our brook flowing along a deep groove in the earth, with dirt piled in a high rirge on each side, of uniform width and grade, and uniformly denuderl of every shred of vegetation. There are no more riftles, no sharled pools, but only constantly flowing silt-laden water. Now, for a few weeks or months, our fishes become literally the "mere ghosts" of their former selves. Owing to the lack of light they all farle to a miform paleness. Since their ford is clestroyed, their leelless shrink, and their heads atsime 
a prominence disproportionate to their customary aspect. But soun the process of redifferentiation begins. Gravelly riffles begin to form. with long stretches of sluggish water between. A few rains scoop out deep holes where the chamnel is narrowed by bridge abutments. Sull frifts of debris furuish cover for fishes that seek it. and offer a richer spot for the beginnings of rooted vegetation than naked glacial till. In a year or two we see a heavy growth of weeds on the banks of the ditch and overhanging the water. A little later a sprinkling of willow and cottonwood appears, and in the water a fringe of Elodca, water cres. water smartweed, Myriophyllum, and many other coarse aquatic plants. At the end of 20 or 30 vears we find that our brook is again something like its former self. It has gravelly riffles, meanclers back and forth within its narrow confines, is choked by dense leds of aquatic plants.

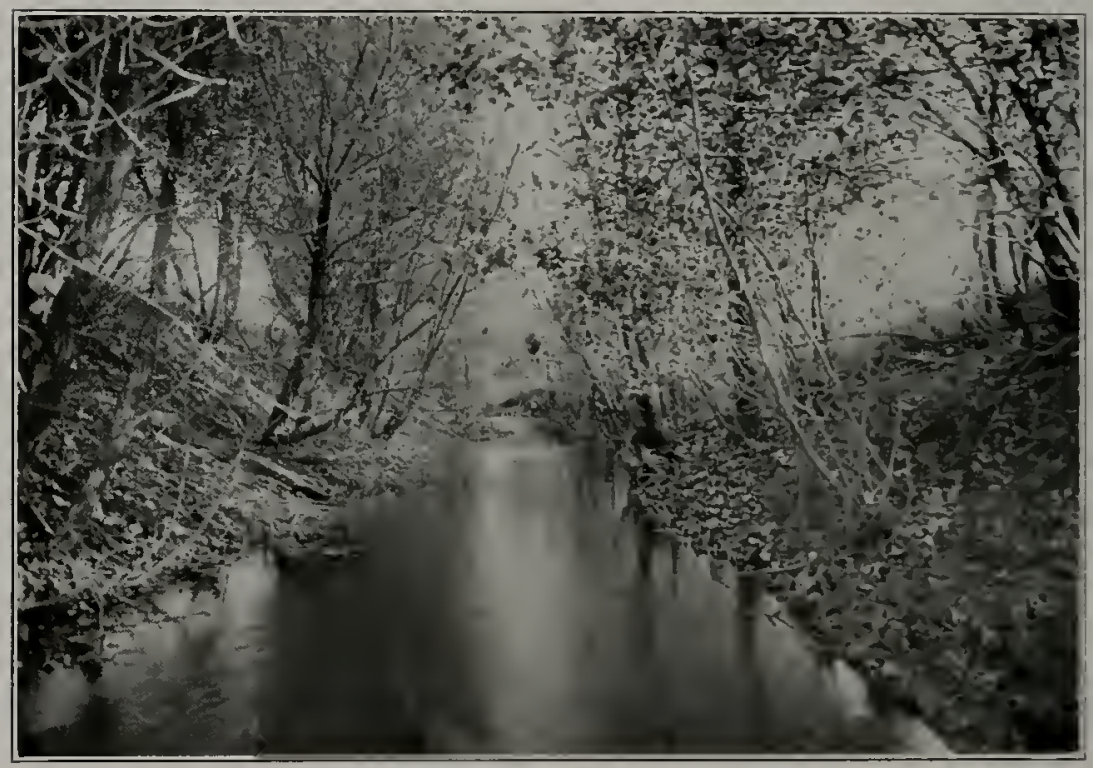

Fig. 4. View of Kaskaskia River near Bendville.

At some places it is open to the sky, hut at others it is thickly overhung by an ever-crowding thicket of willows and other small trees. Deep. shaded pools are also found ahout the roots of these newly grown trees. The vegetation checks the flow of water: the ditch fills up with silt from the fields; and then the dredging machine comes plodding up the strean again.

Dredge ditches showing this cycle of change are mumerous in the county, and exauples of all the different stages can he inund within a single stream system such as the Kaskaskia. When the fishes of an old ditch are compared with the fishes of a new ditch, no nutstanding difference is secn except that certain regetation-loving forms, such as the pirate-perch and the grass pike, are temporarily alosent in the new 
ditch. As for the rest of the fishes, we get about the same numbers and alout the same proportion of the different species.

The slope of headwater streams in the county is commonly 10 to 15 feet per mile. Farther downstream the ustual slope is 3 to 5 feet per mile. While the slope of one stream may be somewhat greater than that of another of the same size, the result is not to produce new kinds of aquatic environment but only to vary the proportion of uniform riffles and miform sluggish reaches. The three larger undredged streams of the county, the Sangamon, the Middle Fork, and the Salt Fork, are very similar and offer to fishes almost exactly the same variety of habitats.

The kind of bottom which a stream has in Champaign County is primarily a function of the rate of flow of the water. The stream

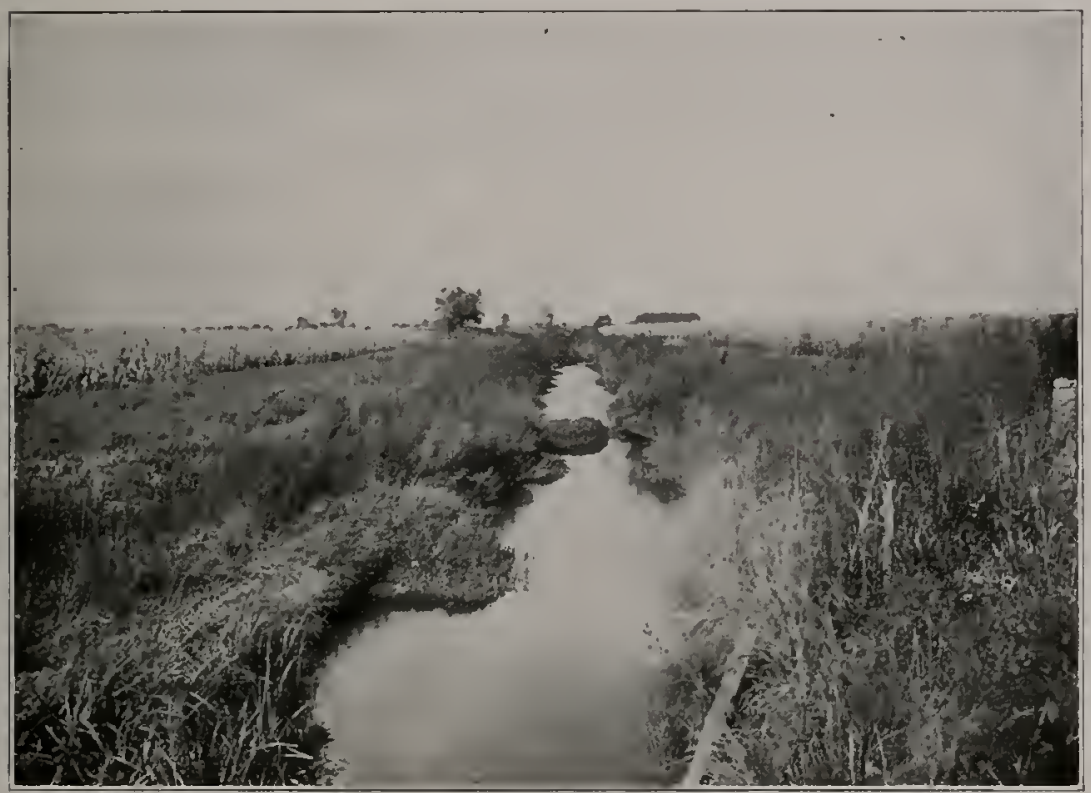

Fig. 5. View of Camp Crcek neat Seymour.

channels are cut in glacial till, which is made up of particles of many sizes, from clay whose particies are 0.0002 inch or less in diameter up to boulders 2 feet across. Owing to the sorting power of water, nothing but rocks and boulders will le found in the swiftest water: peblbles and rocks on ordinary riffles; gravel and sand in smoothly flowing stretches; while the silt and clay is carried along and dropper in deep, wide places and eddies and wherever the movement of the water is checked. The kind of bottom determines very largely the kind and amount of food organisms for fishes and is thus an important factor in their distribution. While rate of flow and kind of botton are closely related causally, more fishes seem to distribute themsclves more of the time according to current than according to kind of bottom. 
Both direct and indirect evidence has been accumulated which shows that in streans of the same size there occur parallel variations in physical characteristics, such as temperature, dissolved oxygen, hydrogen-ion concentration, turbidity, ice conditions, flood conditions, kind of bottom, depth, vegetation, and available fish food.

Permanency of flow is a factor of prime importance to the fishes of small streams. The point above which a stream is reduced to a series of shrumken pools in dry weather varies from 2 to 10 square miles of drainage area, depending on the lay of the land, kind of soil, drainage improvements, etc.

Stream size, in this paper, has been expresser in square miles of drainage area. A calculation based on the average annual rainiall, as measured by the U. S. Weather Burean at Urbana, and on the average run-off of various county streams, as measured by Mr. R. A. Norton, engineer of the U. S. Department of Agriculture, gives an arerage annual flow of almost exactly one cubic foot per second per square mile. This may be used as a rule of thumb to translate statements of drainage area (square miles) directly into terms of average annual flow (cubic feet per second), since the two are numerically equivalent. From the point of view of this paper a precise statement of the average annual flow of the varions streams would be valueless because it represents a stage of water which is attained only occasionally as a stream is rising to, or receding from, a flood. The actual flow for all but a rery small fraction of the total time is either more or less than the annual average.

Pollution by sewage, which is one of the most important factors affecting the variety and abundance of fishes in certain streams of the county, will be discussed separately (pp. $50-57$ ).

The oxygen content of mpolluted streams in Champaign Comnty varies from about 6 parts per million up to super-saturation due to the production of oxygen by chlorophyll-bearing plants in sumlight.

The $\mathrm{pH}$ varies from 6.5 to $\$ .3$. with most realings hetween 7.2 and 7.8 .

The turbidity, maturally, is extreme during freshets: but during ordinary or low stages of water, small objects on the bottom conmonly can be seen through a foot of water in winter and 3 to 6 inches in summer, the comparative clearness in winter probaloly being dre in part to the inactivity of the fishes and the lesser development of the plankton. The clearest strean in the county is the most heavily polluted part of the Salt Fork, and its clearness is probably due to the alnost complete alsence of fishes. Accurate measurements of turbidity were made at the beginning of this study lut were soon discontinued because in many cases the roiliness was directly traced to ditching machines, bridge building, livestock wading in the water. and other temporary disturbances.

Temperatures in local streams vary from freezing in winter to $90^{\circ} \mathrm{F}$. in unsharled stretches in mid-summer. although the variations, of course, are not quite so alorupt nor so great as in the air. Most fishes are sedentary and do not feed or grow much when the water is at or near the freczing point. The growing scason for most of the local fishes is probably abont seven months-from sometime in March or early April until October or early. November. Lsually for a month during every 
winter, the streams are completely frozen over except for the riffles, and on the more slowly moving stretches ice may form to a thickness of 12 or more inches. In summer, there is great variation in the temperature of the water at different places in the streanis, depending on the amount of shade.

The Middle Fork, the Salt Fork, and the Sangamon, before leaving the county, form narrow flood plains which may reach a quarter-mile or more in width. At ordinary or low stages of water each of these streams flows between steep earth banks, 4 to 8 feet below the flood plain, but at least once each year the water rises 10 or 15 feet and covers the flood plain.

The common coarse aquatic plants of the county have been observed, and specinnens have been identified by Mr. L. R. Tehon, Botanist for the Illinois Natural History Survey. A list follows:

Cladophora glomerata-streamers attached to stones of riffles and rapids of the larger streams.

Cladophora crispata-forming mats in quieter water of streams and ponds.

Fissidens Julianus-moss. On top of submerged rocks in the swiftest water of the Middle Fork and Sangamon.

Equisctum hiemalc - horse tail. On ditch banks, etc.

Typha latifolia-common eat tail. In mud and shallow water at the headwaters of small streams.

Sparganium st.-bur reed. In mud and shallow water along small streams.

Potamogcton amcricanus, $P$. hetcrophyllus, $P$. zostcrifolins, and $P$. pusillus-Submerged in small flowing streams.

Sagittaria hetcroplyylla-arrow leaf. Muddy banks of streams.

Elodea canadcnsis-In small flowing streams.

Grasses and sedges of various species. In and along streams.

Scirpus ralidus, S. fluziatilis, and $S$. atrozirons-bull rushes. In and along streams.

Lemna minor-duck weed. Floating and on muddy margins.

Spiradcla polyrhiza-duch weed. Floating and on muddy margins.

Juncus stp. - rushes. On muddy banks of streams.

Salix spp.-willows. Along streams of all sizes.

Rumex crispus-common dock. In or near the water in many situations.

Rumex a'crticillatus-swamp dock. In swampy places.

Folygonum Hydropiper-water smartweed. Abundant in sluggishly fowing streams and ditches of small size.

Nymplaca adzena-yellow water lily. In sluggishly flowing pools.

Ramunculus aquatilis-butter cup. Muddy banks.

Radicula Nasturtium-aquaticum-water cress. Small flowing streams.

Collitriche st.-water starwort. Small flowing streams.

Jussiaca diffusa-primrose-willow.

Myriophyllum hetcrophyllum-squirrel tail. Shallow water and muddy banks of small streams.

Dianathera americana-water willow. Gravelly and rocky shallows and shores of small swift rivers.

Cephalanthus accidentalis-button bush. Swampy flats along the larger streams the county.

Ambrosia trifida-giant ragwced. Fertile banks and flood plains.

Bidcus frondosa, B. cermu, and $R$. spp.-Spanish needles, beggar's ticks. Along streams. 


\section{Methods and Equipanext}

In plamning this quantitative study of Champaign County fishes it was foreseen that the important sources of error would likely arise in the collection of the fishes and the distribution of the samples. As has leen stated before, all of these streams are small, with depths ranging from an inch to 3 feet at ordinary stages of water. Most kinds o $\overline{\mathrm{t}}$ fishing apparatus are highly selective and particularly so if any movement or other reaction of the fishes is necessary for their capture. It was decided that a single piece of fishing apparatus would give most uniform results, and for this a "common-sense" minnow seine was chosen, 10 feet long and 4 feet wide, with meshes $1 / 6$ inch square. Ot the 132 collections 127 were made with this seine, and the other 5 with an inch-mesh seine, 75 by 6 feet. which took only larger fishes. In subsequent treatment of the data the collections made with the latter seine were properly weighted and made to apply only to the larger fishes. Several years of experience with small seines in many kinds of situations, as well as continual estimation and measurement of the area covered per haul, indicated that in such small streams, with the same persons fishing in the same manner, a 10 -foot minnow seine took fishes efficiently from 10 square yards, a 12 -foot minnow seine from 15 square yards, and a 30 -foot minnow seine from 50 square yards. The 75 -foot inch-mesh seine used was estimated to inchule 100 square vards. The 1/6-inch mesh used in this study took fry of the smallest sizes identifiable.

Another factor of great importance in making such quantitative studies of fishes is the skill and efficiency with which the equipment is used. The success of this phase of our work is due to the ingennity and skill of the junior author in gathering up. not a few of the fishes. but almost all of them from a given area. Without someone who. through long experience, is thus able to collect fishes from the different situations efficiently, it would be practically useless to attempt quantitative work.

The collections are distriluted over all the seasons of 1928 from early spring to late autumm, and for this reason the data not only present the average of a year's collecting but also indicate many instances of changes in detailed distrilution of species.

While an attempt was made to do the collecting at ordinary stages of water, it nevertheless happened that the collections in some streams were made at higher stages and, hence, at consirlerably greater dilutions than in others which were ahmomaly low. The order of the stream systenus according to their average stages of water when the collections were made. from greatest dilution to greatest concentration, is as follows: (1) Embarrass, (2) Kaskaskia. (3) Salt Fork, (4) Little Vermilion, (5) Sangamon, (6) Middle Fork. Differences in mumber of fishes per unit area clue to differences in dilution may le as much as 50 to 75 per cent hetween the cxtrencs, that is. lecween the Einharrass and the Middle Fork stream sistems. 
An effort was made to make collections as closely as possible proportional to water area. The following talulation shows the number of collections and the total area collected over in streans of different sizes :

\begin{tabular}{c|c|c}
\hline $\begin{array}{c}\text { Stream size } \\
\text { in square miles } \\
\text { of drainage area }\end{array}$ & $\begin{array}{c}\text { Number of } \\
\text { collections }\end{array}$ & $\begin{array}{c}\text { Total area } \\
\text { of collections } \\
\text { in square yards }\end{array}$ \\
\hline $1 / 2-1$ & 5 & 140 \\
$1-2$ & 5 & 97 \\
$2-4$ & 7 & 345 \\
$4-8$ & 21 & 985 \\
$8-16$ & 22 & 1230 \\
$16-32$ & 15 & 938 \\
$32-64$ & 19 & 1670 \\
$64-128$ & 12 & 1325 \\
$128-256$ & 1.3 & 1360 \\
$256-512$ & 13 & 1450 \\
\hline
\end{tabular}

While smaller streams were samplerl at intervals of 5 to 10 miles, larger streams were sampled every 1 or 2 miles. Collecting points were marked on our field maps in the laboratory prior to the actual collecting. We dicl not travel about over the country milil we found a likely spot and then stop and fish. When a collecting point was reached our attention was directed primarily to making a composite collection representing proportionally, as far as possible, the various aquatic situations presented.

Two to four men made up the field party and travelled to and from the laboratory by automolile. The work was much facilitated by the large amount of paved highway in this county.

Since most of the collections were made near bridges, the locations were recorded by township, range, and section numbers as well as by name of stream and distance and direction from the nearest town, so that it will he possible to duplicate the sampling in the future if it is found desiralle. Accession numbers were entered on the field map, which was a Soil Survey map cut into 12 pieces and mounted on pages in the field notebook.

The drainage areas of the various streams at each of the 132 points of collection were rletermined by marking out the rlainage areas on U. S. Geological Survey and Illinois Soil Survey maps and measuring with a planimeter. While it is possible to express strcam size as average amnual flow in culic feet per second. it has been thought best to leave it in square miles of drainage area (see alove, p. 12).

The 132 quantitative collections of fishes male within the county in 1928 included 28.905 specimens, an average of some 220 fishes per collection. The area included in individual collections varierl from 10 to 250 square yards, lut $82 \%$ of the collections were marle in areas of 
more than 40 square yards. Before statistical treatment of the data was begun, all collections were reduced to numbers per 100 square yards.

One of the reasons for doing this intensive work was to permit a direct comparison with earlier collections made in Champaign County. This county was collected over at that time as thoroughly as any other part of the state, with collections clistributed as follows: 1 in 1882, 3 in 1885, 1 in 1892, 2 in 1898, 22 in 1899, 3 in 1900, and 8 in 1901. The distribution of both recent and older collections by stream systems is as follows:

\begin{tabular}{l|c|c|c}
\hline \hline \multirow{2}{*}{ Stream system } & $\begin{array}{c}\text { Square miles of } \\
\text { drainage area } \\
\text { in the county }\end{array}$ & \multicolumn{2}{|c}{ Number of collections } \\
\cline { 3 - 4 } & 346 & $1882-1901$ & 1928 \\
\hline Salt Fork & 227 & 8 & 52 \\
Sangamon & 138 & 3 & 32 \\
Embarrass & 168 & 2 & 20 \\
Kaskaskia & 69 & 3 & 15 \\
Middle Fork & 40 & 0 & 4 \\
Little Vermilion & & - & -132 \\
Total & 988 & 40 & 13 \\
\hline
\end{tabular}

The net most generally used was treated for preserwation with a light coat of pine tar, which was applied by diluting the tar with an equal amount of acetone.

Two or three square 5-gallon malted-milk cans with a 5-inch opening were used for storing collections temporarily in a strong formaldehyde solution. The fishes were dumped directly from the net into a 14-quart pail about half-full of strong formaldehyde solution, in which they died with the fins extencled, the mouth and gills closed, and the body straight, making excellent specimens. The formaldehyde kills and hardens them so quickly that scarcely a scale is lost or a fin tattered. and the contour of the body is not in the least distorted. The latter fact is imporant because the confusion in the identification of certain groups. such as the genera Carpiodes and Ictiobus, seems to be clue primarily. to distortion in preserved specimens. Miscellaneous small bottom animals were thrown into the pail with the fishes and taken to the automobile or boat, where all were transferred to a bag made of a good quality of cheese cloth and measuring 12 by 17 inches. In order to avoid getting the formaldelyde on our hands, the transter of the fislies. ctc., from the pail to the bag was made by putting the emply bag into the malted-milk can with the mouth of the bag lapped back over the lip of the can and fastence with a cord or a lieary rubler band. The bucket was emptied into the mouth of the hag, a slip of paper dropped in with an accession number corresponding to a page number in the loose-leaf field notehook, the mouth of the hag ticd. and the whole stored in strong formaldchydc in a can of the kind described above. All the fishes collected were preserved exçept about a thousand which were 
large and offered no difficulty in ilentification and which were returned to the water. Notes macle in the loose-leaf field book were removed daily, and later typed in triplicate, as is our regular procedure for field notes. The laboratory identifications were entered on the back of each page of the notes.

Within a day or two after the collections were nuade they were sorted and identified in the laboratory by the junior anthor and checked by the senior author. Mr. R. E. Richardson kindly checked nuny doubtful specimens and all of several doubtful and variable species. His help in this respect lends confidence in comparisons to be nuade with earlier collections which he identified. At the present time there is an unidentified residue of only 2 or 3 juvenile specimens.

The data were tabulated on large sheets of co-ordinate paper with half-inch squares. Across the top of each table were colmm headings for accession number, location, date, drainage area, depth, width, rate of flow, kind of bottom, submerged non-living cover (such as brush, logs, debris, ctc.), aquatic vegetation, shade, turbidity, temperature, the factor used to reduce actual numbers of fishes taken to numbers per 100 square yards, and finally the names of the 74 species of county fishes. In these columns were tabulated the field data and numbers of each kind of fish in each collection. The collections were arranged in the order of their upstream-downstream occurrence in each stream. In the columns under the names of the fishes. the actual numbers taken and the calculated numbers per 100 square yards were cntered. Horizontal and vertical totals were made and checked against each other. These tables were then used as the basis for all subsequent calculations and are preserved in the files of the Illinois Natural History Survey.

\section{LIST OF SPECIES, WITH ANALYTICAL KEYS AND DATA ON DISTRIBUTION AND ABUNDANCE}

The following list of the species of fishes taken in Champaign County is presented especially for the use of collectors in this area. For the sake of conformity the scientific names and the gencral arrangement are the same as in "The Fishes of Illinois" by Forbes and Richardson (1909) except that some of the common names have bcen changed to conform with local usage. An appendix (page 98) lists those Champaign County fishes which have revised manes in Jordan's "Manual of the Vertebrate Animals of the Northeastern United States" 13th edition, 1929. Notes have been added in some cases for the convenience of the collector.

The data shown here are frased on 132 quantitative collections made in 1928 which included 28,905 specimens, with the adclition of three species (Ictiobus bubalus, Hybopsis storcrianus, and Ethostoma jessiac) represented by single specincus taken in the earlice collections of the Illinois Natural History Survey, and two other rearlily recognized large species (Anguilla cliysypa and Leptops olizaris) takcin by anglers in 1928. 
The habitat numbers refer to an ecological classification of Clampaign County streams and fishes which follows (pages $34-39$ ). Several habitat numbers following the name of a species indicate that it occurs most frequently in the first habitat, and so on. with its least irequent occurrence in the last habitat. Maps are appended showing the local distribution of all species represented by ten or more specimens in the collections of 1928. An explanation of these maps is given on page 71 .

The distribution of a species is described as "restricted" when it is absent from one or more of the stream systems in which its preferred habitat or habitats generally occur. In labelling certain species as "restricted," it has been necessary to take into account the number of specimens collected, since by randon sampling it is within the realm of probability that a few specimens of a rare species may be taken in one stream system and not in others in which they may nevertheless occur. The word "restricted" used in connection witl" these species implies a spotty distribution and a high degree of isolation.

The following analytical keys to the Champaign Connty fishes have heen adajted directly from the Forbes and Richardson keys, but a few minor modifications have been made, mostly within the family Catostomidac.

\section{KEY TO THE FAMLIES OF CHAMPAIGN COLNTY FISHES}

a Dorsal fin with no spines, or with only 1 . Pelvic fin without spine.

b Head naked.

c Body scaled (scales small and obscure in the eel). Head without barbels or witl not more than 2 or 4.

d Gill membranes free from the isthmus, i. e., split far forward and meeting in an acute angle.

e Lateral line present. (Moon-eye)

Hiodontidae

ee Lateral line wanting. Last rays of dorsal fin much elongated. (Gizzard-shad)

Dorosomidae

dd Gill membranes more or less hroadly joined to the isthnus, not meeting in an acute angle.

f Pelvic fins wanting. Body cel-shaped. (Eel)

Anguillidae

ff Pelvic fins present. Body not eel-shaped.

g Pharyngeal teeth numerous and comb-like. Mouth fitted for sucking. Lips more or less thick and plicate or papillose. (Suckers). Catostomidae

gg Pharyngeal tecth fewer than 8 on each sidc. Lips thin and never plicate or papillose. Dorsal fin of not more than 10 rays. (Minnows) .... Cyprinidae

cc Body and head naked. Eight long barbels about the moutli. (Catfishes) Siluridae

bb Head scaled. Rody completely scaled.

h I.ateral line present. Front of head shaped like a duck's bill. (Pike)

Esocidae

hh Lateral line wanting. Mouth small and upturned. (Topminnow) 
aa Dorsal fin with more than one spine. Pelvic fin with a spine.

i Insertion of pelvic fins distinctly nearer the anal fin than the throat. First dorsal separated from the second and composed of 4 weak spines. (Silverside)

Atherinidae

ii Insertion of pelvic fins distinctly nearer the throat than the first soit ray of the anal.

j Vent in front of pectorals. (Pirate-perch)_.__................. Aphredoderidae jj Vent normal.

$k$ Anal spines 3 to 10 . (Sunfishes)

Centrarchidae

kk Anal spines one or two.

1 Lateral line not extending onto the rays of the caudal

fin. (Darters)

Percidae

11 Lateral line extending onto the rays of the caudal fin.

(Sheepshead)

Sciaenidae

Family HIODONTIDAE-The Moon-eyes

Hiodon tergisus-Moon-eye : toothed herring.

1 coll. 1 spm. Habitat 9.

Fanily DOROSOMIDAE-The Gizzard-shad

Dorosoma cepedianum-Gizzard-shad; hickory shad.

2 colls. 17 spms. Habitat 9.

Fanily ANGUILLIDAE-The Eels

Anguilla chrysypa-Eel.

One reported taken in 1928 from the Embarrass River above Villa Grove.

Family CATOSTOMIDAE-The Suckers

Key to the Genera

a Dorsal fin elongate, with 25 to 40 developed rays.

b Distance from eye to lower posterior angle of preopercle about $3 / 4$ of that to upper corner of gill-cleft. Subopercle broadest at its middle, sub-semicircular. (Buffaloes). Ictiobus

bb Eye about equidistant between upper corner of gill-cleft and the lower posterior angle of preopercle. Suhopercle broadest below its middle, sulbtriangular. (Carp-suckers).....Carpiodes 
aa Dorsal fin short, with 9 to 18 developed rays.

c Lateral line more or less incomplete or wholly wanting. Scales large and uniformly distributed, 30 to 50 in lateral line.

d Lateral line entirely wanting at all ages. Mouth subinferior, somewhat oblique. Young with wide, black lateral band breaking up into about six dark blotches in adults. (Chub-sucker)

Erimyzon

dd Lateral line more or less developed in adults. Mouth inferior, horizontal. One dark squarish spot in center of each scale. (Spotted sucker).

Minytrema

cc Lateral line complete and continuous,

e Scales small and crowded anteriorly. The number in the lateral line 55 to 110 (Except C. nigricans for

which see below ee). (Suckers)... - .........
ee Scales large and nearly cqual all over the body, to to 55

Catostomus in the lateral line.

f Air-bladder in two parts. Scales $48-55$ in lateral line. (Hog sucker) .......................... Catostomus (Hypentelium) nigricans

ff Air-bladder in three parts. Scales larger, 40 to 50 in lateral line. (Red-horses)

Moxostoma

\section{Key to the Species of Ictiobus}

a Mouth large, oblique. Upper lip about on level with lower margin of orbit. Angle of mandible with horizontal more than $40^{\circ}$

cyprinella

aa Mouth smaller, little oblique. Level of upper lip ahout midway between chin and lower margin of orbit. Angle of mandible with horizontal slight, less than $20^{\circ}$

b Back scarcely elevated. Depth 3 to $31 / 4$ in length. Body of adults subcircular at front of dorsal. - urus

bb Back elevated. Depth $2 \frac{1}{2}$ to $23 \%$ in length. Body strikingly compressed in adults bubalus

Ictiobus cyprinclla-Red-mouth buffalo: big-mouth buffalo. 1 coll. 3 spmis. Habitat 9.

Ictiobus urus-Mongrel buffalo; round buffalo. 1 coll. 1 spm. Habitat 8 .

Ictiobus bubalus-Small-mouth buffalo: high-back buffalo. One taken in 1901 in Sangamon River. See Forbes and Richardson (1909).

\section{Key to the Specics of Carpiodes}

a Distance from anterior nostrif to end of sucut less than diameter of eye. Snout blunt, squarish at tip. Profile of head flattish or slightly concave. Eye large, 334 to 4,2 in head... difformis

aa Distance from anterior nostril to end of snout greater than diameter of eye. Snout pointed at tip. profile of head convex. Eye small, $43 / 4$ to $51 / 2$ in head velifer 
Carpiodes difformis-Blunt-nosed river carp.

4 colls. 30 spms. Habitat 9.

Carpiodes velifer-Quillback; silver carp.

9 colls. 13 spms. Habitats 8, 6, 9.

Erimyzon succtta oblongus-Chub sucker; sweet sucker.

48 colls. 196 spms. Habitats $1,5,4,6,8,9$.

Minytrema melanops-Spotted sucker; striped sucker.

5 colls. 18 spms. Habitats 9, 8, 5 .

\section{Key to the Species of Catostomus}

a Head transversely convex above. The orbital rim not elevated. Scales in lateral line, 60 or more, crowded and smaller anteriorly

commersonii

aa Head broad, depressed, transversely concave between the orbits. Scales nearly equal all over the body, not crowded anteriorly, 48 to 55 in the lateral line.

nigricans

Catostomus commersonii-Black sucker; fine-scaled sucker.

65 colls. 644 spms. Habitats 8, 5, 6, 9, 4, 2, 7.

Catostomus nigricans-Hogsucker; stone-roller.

27 colls. 64 spms. Habitats $7,8,6,5$.

\section{Key to the Shecies of Moxostoma}

a Folds of lower lip more or less broken up into papillae.

b Head short, $4 \frac{1}{2}$ to $5 \frac{1}{2}$ in body. Caudal fin pink to bright red outward. Base of scales dark, giving a cross-hatched appearance. Developed dorsal rays 12 or 13 breviceps

bb Head longer, $3 \frac{\mathrm{T}}{2}$ to $4 \mathrm{~T} / 2$ in body. Mouth large. Developed dorsal rays 14 to 16 . Back elevated. Color silvery.

Anisurum

aa Lips strongly plicate. Head $+t o t / 2$ in body. Caudal grayish olive to lemon. Outer margin of scales with dark stippling. Mouth large. Developed dorsal rays 12 to 1 .

Back scarcely elevated. Color bronze above lateral line.

aureolum

Morostoma anisurum-White-nosed sucker.

One adult taken in September, 1929, from Sangamon River five miles above Mahomet.

Mornstoma aurcolum-Common rer-horse; white sucker. 22 colls. 114 spms. Halitats 8. 9. 7, 5, 6.

Moxostoma meviceps-Short-headed red-horse; red-tail.

6 colls. 11 spnis. Habitats $8,9,6$. 


\section{Family CYPRINIDAE-The Minnows and the Carp}

\section{KEY TO THE GENERA}

a Dorsal fin elongate. Dorsal and anal fins each with a strong serrated spine. Teeth molar or submolar. (Carp) Cyprinus

aa Dorsal fin short. No spines in fins. Teeth not molar.

b Intestine more than twice length of body. Peritoneum usually black, brown, or dark gray. Generally mud-eaters.

c Intestine spirally wound around air-bladder

Campostoma

cc Intestine not wound around air-bladder.

d Scales before dorsal 12 to 16 in number, not crowded...... Hybognathus dd Scales before dorsal small and considerably croweded. 22 to 25 in number

Pimephales

bb Intestine less than twice the length of body. Peritoneum usually pale. Generally carnivorous, or partly so.

e Maxillary without barbel.

f Mouth extremely smal] and upturned, the angle with vertical formed by its cleft less than $40^{\circ}$.

ff Mouth horizontal or more or less oblique, the angle with vertical formed by its cleft usually more than $40^{\circ}$.

g Abdomen behind ventral fins with a sharp keel-like edge over which the scales do not pass. Body. much compressed. Anal fin long, its rays 12 to 14

gg Abdomen behind ventrals never sharply keeled, but rounded and fully scaled. Form various, elongate or fusiform, or more or less compressed.

h First (rudimentary) ray of dorsal club-like, corered with thick skin, and separated from second ray by a distinct membrane...

Abramis

hh First (rudimentary) ray of dorsal slender and bony and closely attached to second.

i Lips normal, nowhere conspicuous!y thickened. Mouth subterminal, more or less oblique.

j Lower portion of head rounded, not swollen. and without externally visible mucus channels

jj Lower portion of head with an appearance of being swollen. The suborbitals, interopercles, and dentaries with greatly distended mucus cavities, appearing externally as transverse vitreous streaks

Ericymba

ii Lower lip with two lateral fleshy lobes, separated at the middle by the more or less horny: and knob-like chin. Scales rather small, to to 60 in lateral line

Phenacobius

ce Maxillary with a barbel at or near its extremity (sometimes quite small and difficult to make out, especially in preserved specimens).

k Barbel on upper side of maxillary and distinctly in front of its posterior tip. Nouth exceptionally large, maxillary 2.4 to 2.8 in head. Scales 50 to 60 
kk Barlsel terninal on the maxillary, situated in the axil formed at meeting of upper and lower lip-grooves. Maxillary more than 2.8 in head. Scales 35 to 45 in lateral line

\section{Hybopsis}

Cyprimus carpio-Carp: European carp.

9 colls. 15 spms. Habitats 8, 9.

Campostoma anomalum-Dough-belly; stone roller. $6+$ colls. $11+6$ spins. Habitats $6,7,8,2,1,4,5$.

Hybognatlus muchalis-Silvery minnow.

9 colls. 68 spmis. Habitats $5,8,6,7$. Restricted to Kaskaskia River basin. Found among submerged vegetation, brush, and other cover.

\section{Key to the Srecics of Pimephales}

a Body short and stout, depth 3 to 4 in length. Lateral line more or less incomplete promelas

aa Body moderately elongate, depth + to 5 in length. Lateral line complete notatus

Pimephales promclas-Fathead minnow: black-head minnow. 19 colls. 103 spms. Habitats 8, 6, 4. Restricted to Sangamon River basin. Found in quieter water of permanently flowing streams.

Pincphales notatus-Blunt-nosed minnow.

110 colls. 6440 spmis. Habitats $4,5,2,6,8,1,7,9$.

Opsopocodus cmiliac-Snub-nosed minnow.

1 coll. 2 spms. Habitat 5.

Abramis crysolcucas-Golden shiner; bream.

41 colls. 401 spms. Habitats 5, 8, 6, 3, 2, 4, 7. Almost invariably found among vegetation or other cover.

Cliola vigila.r-Bullhead minnow.

4 colls. 24 spms. Hahitat 8 . Restricted to the Sanganon River and the East Branch of the Salt Fork. Found in shallow. quiet water with mud, bottom and no regetation, cover or shade.

\section{Key to the Species of Notropis}

a Anal rays typically 7 or 8 , occasionally 9 in two compressed forms (sce bb bclow), in which however, scales before dorsal are not over 17, and no black spot is present at base of first dorsal rays.

b Eye moderate, $2 \frac{1 / 3}{3}$ to $2 \frac{2}{3}$ in head, always less than 4 . Body not usually much compressed, the body gently and broadly rounded in front of dorsal fin. Scales not closely imbricated.

c Eye 3 or more in head. Small, usually less than $2 \mathrm{~J} / 2$ inches. 
d Scales before dorsal large, 12 to 15 in number.

e A black stripe along sides through eye to end of snout. Chin white. Mouth small, nearly horizontal. cayuga

ee A dark vertebral streak, and a plumbeous lateral band more or less distinct posteriorly. Mouth more or less oblique. Lateral line distinctly decurved anteriorly blennius

dd Scales betore dorsal smaller, 17 to 10 in number. Mouth inferior. Lips rather thick. gilberti

cc Eye very large, $2 \frac{1 / 3}{3}$ to $23 / 4$ in head. Dark lateral stripe not developed anteriorly. Some dusky color on chin at tip. Length 3 inches

-illecebrosus

bb Eye small, + to 5 in head in adults. Body more or less distinctly compressed, the back sharply rounded in front of dorsal fin. Scales closely imbricated. Adults with depth $3 \frac{1}{2}$ to 4 in length. A more or less distinct black blotch on last nembranes of dorsal. whipplii

aa Anal rays 9, 10, 11, or 12 .

$f$ Dorsal in front of or over ventrals. Exposed portions of scales of flanks notably deeper than long. A broad dark vertebral streak. Aanal rays 9 to 10 , usually 10.

cornutus

ff Dorsal fin behind ventrals. Scales roundish, the exposed portions not notably deeper than long.

g Scales loosely imbricated, those before dorsal in 15 to 17 series. No black spot at base of dorsal.

h A dark vertebral streak. Anal rays 9 or 10

hh Vertebral streak very narrow and usually faint. Snout blunt. Maxillary equal to eye..._................... atherinoides

gg Scales closely imbricated, about 30 series in front of dorsal. A black spot usually eviden at tront of base of dorsal. Anal rays 10 to 12, usually 11... . _ _.......

umbratilis

Notropis cay'uga atrocaudalis-Cayuga minnow. 1 coll. 1 spm. Habitat 8 .

Notropis blcunius-Straw-colored minnow. 44 colls. 1573 spms. Habitats 8, 6, 7, 5. 1.

Notropis gilbcrti-Gilhert's minnow.

5 colls. 53 spms. Habitats $6,8,5$. Restricted to Sangamon River basin. Found in shallow, quiet water over sandy bottom.

Notropis illcchrosus-Big-ered mimnow.

2 colls. 8 spms. Habitat 7. Restricted to Middle Fork River. Found below rapids among stalls of the water willow, Dianthera ancricana.

Notropis athipplii-Steel-colored minnow: silverfin.

53 colls. 1994 spmes. Habitats 8, 7. 6, 4. 2. 5. Founci on or near riffles and briskly moving water. Strong swimmer. 
Notropis cormutus-Shiner; horned shiner.

54 colls. 2618 spms. Halitats 5, 6, 7, 8, 4. 2, 9. Found abundantly in Sangamon. Middle Fork, and Kaskaskia River basins. A few specimens taken in Salt Fork Basin. Very closely associated with Hybopsis kcutuckiensis.

Notropis pilsbryi-Pilsbry's minnow.

6 colls. 17 spms. Habitats 5,6 .

Notropis atherinoides var.-Shiner.

3 colls. 21 spms. Habitat 7. Restricted to Middle Fork River.

Notropis unbratilis atripes-Blackfin minnow.

69 colls. 1108 spms. Habitats $6,5,8,7$, in about equal frequency. Shows preference for vegetation or other cover.

Ericumba buccata-Silver-mouthed minnow.

79 colls. 3519 spmis. Habitats 2, 6, 5, 8, 7, 4. Found most often and in largest numbers over sand bottom.

Phenacobius mirabilis - Sucker-nouthed minnow. 24 colls. 102 spms. Habitats 8, 6, 7, 5.

Semotilus atromaculatus-Horned dace: creek chub.

101 colls. 2873 spms. Habitats $4,2,1,6,5,8,7,3$.

\section{Key to the Species of Hybopsis}

a Upper jaw decidedly inferior, lying below the projecting snout. Preorbital much narrower than eve. No nuptial tubercules. Upper jaw reaching eye.

b Size small, 2 to 3 inches when adult. Dorsal fin inserted over origm of ventrals, usually a little nearer caudal base than tip of snout. Dark lateral stripe. Color silvery. Upper jaw 3.6 to 4.6 in head amblops

bb Size large. 4 to 10 inches when adult. Dorsal fin inserted distinctly in advance of ventrals, decidedly nearer snout than caudal base. Color silvery without a dark lateral stripe. Upper jaw 3.2 to 3.7 in head _.........................

aa Upper jaw almost terminal. Snout rather conical. Preorbital much wider than eye. Nuptial tubercles very strong. Large fishes with the aspect of Semotilus.

kentuckiensis

Hybopsis amblops-Big-eyed chul, : silver chub.

8 colls. 40 spms. Habitats 8, 6. Restricted to Middle Fork, Salt Fork, and Embarrass rivers. 
Hybopsis storcrianus-Storer's chub.

One taken in 1899 in Middle Fork River. See Forbes and Richardson (1909).

Hybopsis kcutuckicnsis-Horny head; Kentucky chub. 46 colls. 1221 spms. Habitats $5,6,7,8,4.9$. Found closely associated with Notropis cormutus in Sangamon, Middle Fork, and Kaskaskia River basins

\section{Family SILURID.AE-The Catfishes}

\section{Key to the Gevira}

a Adipose fin with its posterior margin free.

b Premaxillary band of teeth without lateral backward extensions. Anal rays 17 to 35 , including rudiments.

c Bony bridge from occiput to dorsal fin complete. Tail deeply forked

cc Bony bridge from occiput to dorsal fin broken. Caudal fin typically rounded, truncate or slightly emarginate ....... Ameiurus

bb Premaxillary band of teeth with a backward extension on eacl side. Anal rays 12 to 15 including rudiments Leptops

aa Adipose fin adnate to the back, continuous with the caudal and separated from it only by a notch.

d Premaxillary band of teeth with lateral backward extensions, as in Leptops. Skin thick tougl, and

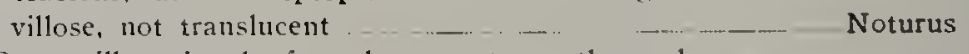

dd Premaxillary band of teeth truncate at the ends, as in Ameiurus. Skin thinner than in $d$, smonth or very finely villose. sometimes translucert _._._._._._....... Schilbeodes

Ictalurus punctatus-Channel cat : fiddler. 8 colls. 10 spms. Habitats $8,9$.

\section{Key to the Species of Ameiurus}

a Anal rays 24 to 27 , including rudiments, usually 25 or 26 . Caudal fin rounded posteriorly. Margin of anal fin : straight line natalis

aa Anal rays 17 to 20 , usually 18 or 19 , including rudiments. Caudal fin always evidently emarginate. Margin of anal fin a curve. melas

Anciurus natalis-Jellow bullhead. 15 colls. 28 spms. Hahitats $5,6,8$.

Amciurus molas-Black bullhead: horned pout.

13 colls. 1704 spms. Hahitats 3, 5, 8, 9. Schools of young found in liabitats 3,5 . 
Lcptops olivaris-Mud-cat ; yellow cat : goujon.

One 24 pound spm. taken August 1928 in Sangamon River by Mr. Homer Bales.

Notwrus flavus-Stonecat.

5 colls. 12 spms. Habitat 7. Found under rocks on riffles.

\section{Key to the Srecies of Schilbeodes}

a Anterior and posterior edges of pectoral spine entire, or the anterior edge very slightly roughened near tip. Jaws equal. Adipose fin continuous with caudal, the notch being absent or faint, never acute. Color purplish olive to dark brownish, without noticeable specking. Three dark streaks on sides gyrinus

aa Pectoral spine with distinct posterior serrae, which are recurved and in length more than $1 / 3$ the diameter of spine. Notch between adipose and caudal fins always more or less acute.

b Pectoral spine short, 3 in head, the posterior serrae not $1 / 2$ diameter of spine. Notch between caudal and adipose fins usually shallow. Color light brown, sometimes faintly mottled. A large squarish spot of lighter color on back before dorsal and a smaller cresentic one behind it exilis

bb Pectoral spine longer, less than 2 in head, its posterior serrae strong and in length nearly equaling diameter of spine. Notch between adipose and caudal fins deep and acute. Color grayish with black specks and larger blotches. Four saddle-like blotches on back, the last but one extending upon adipose fin to its edge.

miurus

Schilbeodes gyrinus-Tadpole cat.

7 colls. 14 spms. Habitats 8, 6. Restricted to Salt Fork River basin.

Sclilbeodes crilis-Slender stonecat.

3 colls. 3 spms. Haluitats $8,7$.

Sclitbeodes miurus-Brindled stonecat.

1 coll. 44 spms. Hahitat 8. Restricted to Salt Fork River basin.

\section{Family ESOCID.AE-The Pikes}

Esox vermiculatus-Grass pike; little pickerel.

26 colls. 63 spms. Habitats 8, 5, 6. Found amongs submerged vegetation or other cover, and in the shade of overhanging lushes. 
lamily POECILIIDAE-The Killifishes

Fundulus notatus-Top minnow.

44 colls. 151 spms. Habitats 8, 5.6. Found most often near aquatic vegetation. Swims comnnonly with back touching the surface film.

\section{Fanily ATHERINIDAE-The Silversides}

Labidesthes sicculus-Brook silverside.

3 colls. 27 spms. Habitat 8 . Restricted to the Salt Fork River basin.

Family APHREDODERIDAE-The Pirate-perch

Aphredoderus sayanus-Pirate-perch.

12 colls. 167 spms. Habitats 5. 8. Restricted to Sangamon, Embarrass, and Kaskaskia River basins. Found among living vegetation or other cover.

Family CENTRARCHIDAE-The Sunfishes

KEX to THE GENERA

a Dorsal fin little longer than anal, if any, its length 1 to 1.4 times length of anal base. Anal spines 5 to 8 in number.

b Dorsal spines 5 to 8 (occasionally 9 or even 10) (Crappies) Pomoxis

bb Dorsal spines 11 to 13 . Anal spines 6 , rays 10 or 11 . (Rock bass) Ambloplites

aa Dorsal more than twice length of anal. Anal spines 3.

c Body comparatively slort and deep, depth in adults as a rule morc than $2 / 5$ of length. Dorsal fin not deeply emarginate, the shortest spinc behind middle of fin more than $2 / 3$ height of longest. Operculum entire behind, not emarginate, more or less prolonged in a bony process or flap with a rounded posterior margin.

d Tongue and pterygoids with teeth. Maxillary reaching past pupil (Warmouth bass)

dd Tongue and pterygoids toothless. Maxillary in most species short of middle of orbit (to middle in $\mathbf{L}$. cyanellus). Pectorals never reaching beyond vertical from base of anal. Opercular flap without red, or if red is prescnt, with the color forming a border and not a roundish spot. (Sunfishes, and the bluegill) Lepomis 
cc Body comparatively elongate, depth about $1 / 3$ length. Dorsal fin deeply emarginate, the shortest spine behind niddle of fin from $1 / 3$ to $1 / 2$ height of longest. Operculum ending in two flat points. (Black basses).

Micropterus

\section{Key to the Species of Pomoxis}

a Dorsal spines typically 6 , rarely 5 or 7 . Color light, the dark markings tending to form vertical bands. annularis

aa Dorsal spines typically 7 or 8 , rarely 6 , 9, or 10 . Color dark, spotted, the dark markings not forming vertical bands ...... sparoides

\section{Pono.tis annularis-White crappie.} 2 colls. 2 spms. Habitat 8 .

Pomoris sparoides-Black crappie. 3 colls. 7 spms. Habitats 9, 8.

Ambloplites rupestris-Rock luass ; goggle-eye. 1 coll. 1 spm. Habitat 8 .

Chacnobryttus gulosus-IVarmouth lass.

2 or 3 spms. collected in recent years near the outlet of Crystal Lake from which they had probably escaped.

\section{Key to the Species of Lepomis}

a Black opercular spot borne by the stiff bony upper posterior angle of the operculum, which is plainly distinguished from a flexible (fleshy or membranous) border of different (usually lighter) color.

b Mouth large and cheek not very deep, the maxillary $1 / 5$ to $1 / 4$ longer than the distance from the lower margin of the orbit to the lower posterior corner of the preopercle. In life with blue spots and vertical bars of dusky. Margin of ear-flap coppery to purplish. Cheeks with wavy blue lines

bb Mouth smaller and cheek deeper, maxillary about equal to or less than distance from lower margin of orbit to the lower posterior corner of preopercle. Many scales of sides with squarish light-colored areas (bronze or purplish in life), these forming more or less distinct longitudinal rows. Rest of body dusky olive ................. miniatus

aa Portion of opercular flap bearing black spot very thin and flexible.

c Bony portion of operculum terminating in front of the middle of the black opercular spot, which is confined chiefly to the broad pale (pinkish in life) membranous (not osseus) border. In life olive with orange spots. Cheeks and opercles with wavy broken lines of rusty orange. No black blotcl at base of last dorsal rays 
cc Bony portion of operculum continued backward as a thin and flexible osseo-membraneous flap, which is all or nearly all black, the longitudinal bone-striae being visible through its ensheathing epidermis.

d Gill-rakers short and weak, their length not over $1 / 6$

eye. No black spot at base of last dorsal rays. Olive with blue and orange spots and wavy vertical streaks of emerald. Checks with wavy lines of emerald. megalotis

dd Gill-rakers rather long and slender, their length nearly $1 / 3$ of eye. A black blotch at base of last dorsal rays. Life color olive, with purplish luster____..._____ pallidus

Lepomis cyanellus-Green sunfish.

38 colls. 121 spms. Habitats 3, 5, 6, 2, 8, 7. t. Usually fotund among vegetation or other cover.

Lchomis Miniatus-Garman's sunfish.

1 spm. collected in 1928 near the outlet of Crystal Lake, from which it had probably escaped.

Lepomis megalotis-Long-eared sunfish.

39 colls. $15+$ spms. Habitats 8, 5, 6, 4, 9. About 20 adults observed building nests and spawning in the Little Vermilion River at the Clampaign-Vermilion County line on August 2, 1928. The stream at this point is a dredge ditch with 3 to 10 inches of water and a muddy gravel bottom.

Lepomis humilis-Orange-spotted sumfish.

13 colls. 35 spms. Habitats 8. 2. 5. 6. Restricted to Sangamon, Salt Fork, and Middle Fork River basins.

Lepomis pallidus-Bluegill.

I spm. taken in 1928 near the outlet of Crystal Lake, from which it had probably escaped.

\section{Key to the Species of Micropterus}

a Month moderate, the maxillary never extending beyond eye, usually a little short of back of orbit. Scales on cheeks in abont 17 rows. Young more or less barred or spotted, never with a black lateral band. dolomieu

aa Month very large, the maxillary in the adult extending past back of orbit. Scales on cheek large, in about 10 rows. Young with a blackish lateral band salmoides

Microptcrus dolomicu-Small-mouthed black bass.

16 colls, 4t spms. Habitats S. 7, 6.9. Ustually found near submerged brush or lngs. Cood swimmer. Commonly jumps clear of water when disturhed. 
Micropteris salmoides-Large-mouthed black bass.

3 colls. 4 spms. Habitats 8,6 . It has been noticed that where this species is found in creeks there is usually a good growth of the water willow, Dianthera americana. Not so active as $M$. dolomieu.

Family PERCIDAE-The Darters

\section{Key to the Genera}

a Pre-maxillaries not protractile, free only at the sides, connected in front with the skin of the forehead, from which they are not separated by a cross groove.

b Cranium not compressed or much clevated back of eyes, its elevation not more than $1 / 3$ of its breadth. Body as a rule more or less slender and littlc compressed, subcylindrical or fusiform. Depth in length as a rule 6 or more. Spring males ordinarily without red or other gaudy coloration.

c Cranium broad between the eyes, the interorbital space 4 to 4.7 in head. Snout pig-like. Darters of large size, reaching a length of 6 inches. (Log perch).................... Percina cc Interorbital space narrower, 5.5 to 9 in head. Smail fishes, ordinarily not over 4 inches in length. Body moderately slender, the depth as a rule about 6 in length (sometines 7).

Hadropterus

bb Cranium more or less compressed and elevated back of eyes, $\Omega^{-}$-shaped, its elevation as a rule noticeably more than $1 / 3$ (to less than $1 / 2$ ) its breadth (except in $\mathbf{E}$. flabellare which has a low spinous dorsal and spring males without gaudy coloration). Fishes with usually more or less compressed and comparatively shortened bodies, the depth in length as a rule less than 6 . Spring males usually with brilliant red, blue, or green coloration.

d Lateral line not noticeably flexed upward anteriorly.

Etheostoma

dd Lateral line conspicuously flexed upward anteriorly, its direction parallel with line of back (least distance between lateral line and middle of back in B. fusiformis about $1 / 4$ depth of hody at same point)

Boleichthys

aa Premaxillaries protractile, i. e., a groove scparating them from the skin of the forehead.

e Groove separating premaxillaries from forehead inferior, not visible except from bclow. Maxillary adnate to the preorbital for most of its length, nearly immovablc. Anal spines 2 
ee Groove separating premaxillaries from forehead superior, easily visible from in front and above. Maxillary separated by groove from preorbital for its entire length. Anal spine single.

f Anal fin much smaller than soft dorsal. Body moderately slender, depth not over 7 in length. Pot hyaline in life

ff Anal fin almost as large as soft dorsal. Body extremely slender, depth in length 8 to 10 . Body hyaline in life

\section{Ammocrypta}

\section{Pcrcina caprodes-Log perch.}

2 colls. 4 spms. Habitat 7.

\section{Key' to the Species of Hadropterus}

a Gill membranes not broadly united at the isthmus, distance from tip of suout to angle formed by their union scarcely. exceeding that to back of orbit. Color pattern longitudinal, the sides marked with a median row of blotches or a moniliform band, above which are longitudinally disposed marblings. Cheeks scaled...

aa Gill membranes united at isthmus in a broad curve, least distance from muzzle to free margin of gill membranes 1.2 to 1.5 times that from muzzle to back of orbit. Head very slender and snout long and pointed. Lateral blotches small and as a rule faint. A very small central caudal spot

phoxocephalus

Hadropterus aspro-Black-sided darter.

24 colls. 45 spms. Halitats 8.5 .6 .7 . Often found among aquatic vegetation or other cover.

Hadroptcrus phosocchlahis-Sharp-nosed darter.

8 colls. 12 spms. Habitats $8,7.6$.

Diplesion Mennioides-Green-sided darter.

10 colls. 149 spms. Habitats 7. \&. 6. Restricted to Middle Fork, Salt Fork, and Emlarrass River hasins. Found on swiftest riffles.

\section{Key to the Specics of Boleosoma}

a Lateral line complete or nearly so. Pyloric cacea 6. Cheeks and breast typically naked, somctimes more or less scaly_...... nigrum aa Lateral line alsent on posterior half of hody. Pyloric caeca 3. Cheeks and opercles, and usually hreast. closely scaled .... camurum

Bolcosoma nigrum-Johnny darter.

82 colls. 993 spms. Habitats $8,5,6,2,4,7$. 
Bolcosoma camunu-Snub-nosed darter.

1 coll. 1 spm. Habitat 5.

Ammocrypta pcllucida-Sand darter.

2 colls. 19 spms. Habitat 8 . Restricted to Mirldle Fork

River. Found louried in sand above riffles.

\section{Key to the Species of Etheostoma}

a Lateral line usualiy complete, occasionally 2 to 6 pores lacking. Gill membranes joining broadly across the isthnus zonale

aa Lateral line always more or less incomplete, the number of pores lacking usually 10 to 30 , rarely as low as 5 .

b Spinous dorsal fin not exceptionally low, its height as a rule 75 to 90 per cent of height of soft dorsal. No enlarged dark humeral scale.

c Cheeks and opercles scaled. Brown bars on sides jessiae cc Cheeks naked. Opercles scaled. Spring males with alternating red and blue bars coeruleum

bb Spinous dorsal fin as a rule less than 60 per cent height of soft dorsal. An enlarged dark humeral scale more or less conspicuous. Gill membranes broadly connected. Dorsal spines each ending in a fleshy knob in the male

flabellare

Ethcostoma zonalc-Banded darter.

8 colls. 85 spmus. Habitats 7, 8. Restricted to the Sangamon River.

Ethcostoma jessine-

One spm. taken in 1901 in Sangannon River. See Forbes and Richardson (1909).

Etheostoma cocrulcum-Rainbow darter.

32 colls. 497 spms. Habitats 6, 7, 8, 5, 4. Not found in the Kaskaskia Basin.

Ethcostoma flabcllarc-Fan-tailed rlarter.

14 colls. 34 spms. Habitats 7, 8, 6. Restricted to Sangamon, Embarrass, Middle Fork, and Salt Fork River basins. Found under and around rocks on riffles.

Bolcichthy's fusiformis-

1 coll. 1 spm. Habitat 6.

Iiamily SCIAENIDAE-The Drums

Aplodinotus grunniens-Sheepshearl; white perch; drum.

3 colls. 10 spms. Habitats 9.8. 


\section{TyPe Habitats}

Habitat numbers given in the preceding species list refer to the following classification of type habitats as found in the streams of Clampaign County. In the selection of these type habitats we have chosen those stream situations which occur repeatedly and have made them correspond. in as far as possible, with what appear to be natural subdivisions in the distribution of the fishes. It is, of course. to be understood that a stream is a continuum and does not break abruptly from one situation into another. There are marked differences in the details of the environment in these type halitats and corresponding differences in the detailed distribution of the fishes.

\section{Type Habitat 1 \\ Terual Rin'ulets}

Commonly draining $1 / 2$ to 2 square miles. Flowing for a few weeks in spring and for shorter periods following heary rains. Completely dry throughout most of the year. One to six inches cleep. Six inches to four feet wide. They are often so small that they can be dammed by one's hand. The substrate is oi exposed subsoil with an accumulation of loam in the depressions. Occasional short stretches of sand bottom may occur depending on the kind of soil being eroded. There are no characteristic bottom muds nor gravelly or rocky riffles. There is usually consiclerable dead vegetation in the form of drifts of leaves, dead weeds. sticks, cornstalks, grass, rtc. No living vegetation except for occasional pieces of sod. The aquatic animal fond present for fishes is restricted almost entirely to water isopods. A considerable number of terrestrial animals are washed in and also serve as food. The typical species of this habitat are as follows:

\section{Erimyizon sucrtta oblongus, young \\ Pinchlali's notalus, young \\ Scmotilus atromaculatus, young \\ Cammostoma anomatum, young}

The above fishes are known to feed extensively on mud and organic debris. The young of a few ather species may occur in small numbers.

\section{Type Habitat 2}

\section{Kettle Holes at Mouths of Tile Drains}

Commonly draining from 1 to 7 square miles. There is a flow throughout the year but it is often reduced to a trickle. [sually 10 to 25 fcet wide and 1 T/3 to 4 feet deep. Water temperature not exceeding $65^{\circ} \mathrm{F}$. in summer and seldom freezing in winter. Very clear. No aquatic vegetation except filamentous alyae. Bottom usually of clay, rock, gravel, and sand. No characteristic dark-colored

5. On the afternoon of July es, 1929, two of these liettle holes were visited and temperatures taken. On that afternonn the air temperalure in the sliade varied around $95^{\circ} \mathrm{F}$. The temperature of one was $63.3^{\circ} \mathrm{F}$. and the other $62.6^{\circ} \mathrm{F}$. The water temperature as it came from the two tiles was tie.s $\mathrm{s}^{\circ}$. and $61.3^{\circ} \mathrm{F}$. . respectively. 
bottom muds. No cover except a little overhanging grass and some submerged trash, dead leaves, and weeds. Very little available aquatic animal food apparent. Grasshoppers and other terrestrial insects fall into the water and probably fill an important place in the dietary of the fishes. No shade. The typical fishes in these situations are as follows:

\author{
Fricrumbi buccata, adults \\ Semotilus atromaculatus, adults and young \\ Pimephates notatus, adults \\ Catostomus commersonii, young \\ Campostoma anomalum, adults and young
}

When the tile outlet is sufficiently low some of these fishes, notably Ericymba and Scmotilus, will ascend the tile for considerable distances where they may feed on subterranean amphiporls and isopods.

\title{
Type Habitat 3 \\ Orbow Ponds along Small Streams
}

Commonly draining $J / 2$ to 1 square mile. Flowing during wet weather. Flooded by adjacent stream during freshets. Usually wide, shallow ponds with a bottom of deep, soft, black, mncky mud. Much dead and decaying regetation. Usually with emergent coarse aquatic vegetation of Sagyittaria, smartweeds, bullrushes, docks, ctc. In summer with heavy growths of blanket algae and duck weeds. Seldom shaded: water extremely warm in summer weather. Freezes almost to bottom in winter. Numbers of frog tadpoles of several species can often be found. Small crayfishes numerous. An abundance of a large variety of aquatic animal food. The typical fishes are as follows:

Ameiurus metas, adults and young

Leponis icyancllus, adults and young

Eso.r i'ermiculatis, adults and young

Abramis crysolencas, adults and young

Occasional young specimens of other species are also found. The conditions of these small oxbow ponds are sometimes approximated in the upper ends of dredge ditches and there the above fishes are also found.

\section{Type Hahilat 4}

\section{Permanenl Heada'ater Streams}

Commonly draining 2 to 10 square miles. Reduced rluring drouths to mere trickles ruming from one shallow depression to another. One inch to one foot deep and six inches to six feet wide. Substrate usually of exposed subsoil but occasional gravelly riffles and beginnings of characteristic bottnm muds are seen. Shaded by a luxuriant growth of cattails, grasses, weeds, willows, and other shrubs and small trces. Water conl. No submerged coarse aquatic vegetation. May have some duck weed and filamentous algae in summer. Available aquatic animal food for fishes not abundant. Numbers of dragon fly and damsel fly nymphs and 
water striders and other bugs. Much food probably falls from the overhanging vegetation. The typical fishes in this situation are:

Sentotilus atromaculotus, adults and young

Pimephales notatus, adults and young

Sometimes the fish population consists entirely of Semolitus. At other times a few specimens of other species may also be found.

\section{Type Habitat 5}

\section{Stretches of Shallow. Sluggish II ater}

Found in both drcdged and undredged streams with a drainage area of 5 to 40 square miles. Reduced to long quiet pools in dry weather. Three to twenty feet wide and $1 / 2$ to $2 \frac{1}{2}$ feet deep. In summer the water is relatively warm and is turbid. In winter covered with heavy ice. The bottom is characteristically of dark mud with an admixture of small amounts of sand, gravel, rock, and sticks. The banks are usually steep and drop off quickly to an almost uniform depth. There is characteristically a growth of a variety of submerged and energent coarse aquatic vegetation, and the channel often is literally choked with beds of water smartweed. Small amounts of shade are furnisherl by overhanging grass and weeds and a few willows. A variety of aquatic aninal foods is present in fair abundance, with Hexagenia nymphs near first place. Crayfishes are common and often are extremely abundant. The typical fishes in this habitat are:

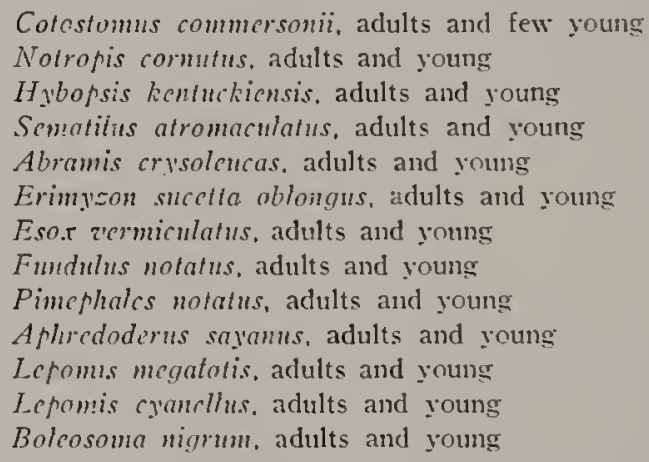

Small numbers of other fishes are regularly taken. This is one of the more important fish habitats inasmuch as it occurs commonly in Clampaign Comty and stipports a large population of a variety of fishes.

\section{Type Hahitat 6}

\section{Gravelly and Sandy Riffles and Strctches}

Drainage arca 8 to 40 square miles. One to 12 fect wide and 1 to $\&$ inches decp. May he a few feet long or sereral hundred yards long. Fither in dredect ditches or in natural streams that lonp and meander. Small flow in dry weather. 
Bottom of gravel or sand, more commonly of both. Often with pebbles ranging up to two inches or more in diameter. Mud along banks and in shallow depressions. Exposed roots of willow, brush, and overhanging sod and grass and shore regetation. Sometimes there are small amounts of coarse aquatic vegetation. Moderate amounts of aquatic animal food. The typical fishes are:

Cotostomus nigricons, young and few adults

Campostoma anomalum. adults and young

Scmotilus atromaculatus, adults and young

Notropis whipplii, adults and young

Catostomus commersanii, young

Notropis comutus, adults and young

Hybopsis kentuckicnsis, adults and young

Pimephales nototus, adults and young

Ericymba buccata, adults and young

Notropis umbratilis atripes, adults and young

Boleosome nigrum, adults and young

Ethcostoma cocrulcum, adults and young

Etheostoma fabellare, adults and young

Mostostoma aurcolum, young

Carpiodes i'clifer, young

Smaller numbers of other fishes are regularly taken.

\section{Type Habitat 7}

\section{Rocky Rapids and Riffles}

Draining 40 to 400 square miles. Depth 2 to 15 inches. Width 5 to 40 feet, very swift except during very low stages of water. Commonly 10 to 100 yards long. Bottom of rocks from the size of eggs up to boulders and loose trap rock interspersed with solidly packed gravel and sand. Occasional logs and brush in water along edges. Rocks overgrown with spreading growths of algae, diatoms, bryozoa, etc., and often serving as anchors for long streamers of Cladophora. An abundance of animal food, consisting principally of small mollusks and immature stages of may flies and caddis flies. This situation occurs in both dredged and natural streams. There are usually trees and shrubs on the banks, which partially shade the water. The typical species of this habitat are:

Catnstomus nigricans, adults

Phenacobins mirabilis, adults and young

Ictalurus pinctatis, young

Ethcostonu flabellare, adults and young

Etheostoma zonale, adults and young

Hylorsis kentuclicnsis, adults and young

Notropis cornutus, adults and young

Notropis whipplii, adults and young

IIybopsis amblops, adults and young

Percina caprodes, adults

Diplesion blemioides, adults and young

Nofurus flaz'us, adults and young 
Small numbers of other fishes taken under certain conditions. The fishes of this situation are mostly adapted to hiding behind and under rocks or other objects that break the full force of the current. These species are seldom seen swimming except for sudden spurts of speed from one stopping place to another. They hold their position rather hy avoiding the full force of the current and clinging than by excellence of swinuming.

\section{Type Habitat 8}

\section{Modcrately Decp, Smoothly Flowing Stretches}

Draining 40 to 400 square miles. Depth 1 to 4 feet. Width 20 to 50 feet. Current sluggish during periods of low water. Bottom of sand and gravel with mud along the banks. No coarse aquatic vegetation. Usually with no overhanging grass or weeds. Commonly shaded by trees on the banks. Roots of trees often exposed and offer hiding places for sunfishes. Numerous drifts of brush and logs and stumps commenly accumulated in places where a large tree has iallen in. The banks usually drop off steeply to a uniform depth. Moderate amounts of a variety of animal foods. Mussels of several species numerous. The typical fishes of this situation are:

Inoxostoma aurcolum, adults

Mnoxostoma breziceps, adults

Carpiades aclifer, adults

Catostomus commersonii, adults

Cotostomus nigricons, adults

Micropterus dolonicu, adults and young

Pomo.tis ammularis, adults and young

Pimephales notatus, adults

Notropis blenuius, adults

Notropis whipptii, adults

Notropis comutus, adults

Hybopsis kentuchionsis, adults

Ictolurus purclatus, adults and young

Lepomis cyancllus, adults and young

I.chomis megalotis, adults and young

Lefomis humilis, adults and young

Other fishes are also taken in smaller numbers.

\section{Type Habital 9 \\ Long. Dect Pools}

Draining 100 to 400 square mules. Width to to 75 feet. Depth 3 in 8 feet. There is less fluctuation of the ply'sical enviromment of this halitat than any other small stream sitnation. Mful botton with more or less gravel and water-logged sticks. Mud hanks. Usually with partly submerged logs and brush along banks. Partly sliaded by trees. Sometimes turbid. No aṇıatic regetation except for water bloom and duck weed in late summer. Usually with aquatic aninal fond 
in the form of small mollusks, Tubificid worms, and chironomid larvae. The typical fishes are:

\author{
Aplodinotus grumicns, adults and young \\ Dorosoma cepcdioum, adults and young \\ Carpiodes difformis, adults \\ Morostoma aurcolum, adults \\ Mo.rostoma breviceps, adults \\ Micropterus salmoides, adults and young \\ Ictiobus cyprinclla, adults and young \\ Cyprinus carnio, adults and young \\ Catostomus connersonii, aduits \\ Pomaris sparoides, adults and young \\ Ictulurus punctatus, adults \\ Amciurus molas, adults
}

Other large fishes are taken in snaller numbers. Scanty numbers of smaller kinds of fishes are taken regularly. Snapping turtles are fotnd here most often. Painted turtles numerous. This situation is the winter quarters of most of the larger fishes.

\title{
Abundance and Number of Kinds
}

In the present quantitative collections a total of 28.905 fishes were taken from a total water area of 9.535 square yards or 1.97 acres-about 15,000 per acre, or 3 per square yard. The total weight of these fishes was estimated at 300 pounds, or about 150 pounds per acre for the county streanns as a whole. This average weight of fish flesh per acre has no obvious relation to the ammul yield of food fishes er to the annual increment.

On the basis of some fragmentary data on the rate of growth of Champaign County fishes and on a general knowledge of the size and relative numbers of the different age groujss of the principal species, one may venture a guess that the ammal increment, or turnover, of fish flesh is something less than one-half of the total 150 pounds per acre.

In this area food and game fishes may be taken only by hook-andline, and minnows may be taken for bait with small minnow seines. In general, the fishes in this county are too small to be attractive to many anglers, and the weight of the fishes taken from the water by man is surely a very small percentage of the anmual increment. In these streams we probably have a close approximation to an equilibrium, or a lsalance wherein the annual increase in fish flesh equals the anmual decrease, and that without undue influence or control hy man. Most fishes in these streams die of "natural" causes-they may be eaten at any period of their life by any one of a variety of predators such as carnivorous insects, crayfishes. necturi, turtles, water and shore birds, or the mink. They nlay be injured or stunted or destroyed by any one of a long and imposing list of specific fish diseases and parasites. Under certain conditions their foor may be exhausted or serious!y depleted. Their anbient medium may dry up or get too hot or freeze solid or he deficient or unsuitable in a number of other ways. Compared with these vicissitudes an occasional worm on a hook is a minor hazard. 
Some recent work of Dr. H. J. Van Clenve and Mr. H. C. Markus on the life history of the blunt-nosed mimow. Pimepliales notatus, in this area suggests that females and males of this species do not exceed 2 and 3 years in age, respectively. The implication is that they die following their first spawning period. (Amcr. Nat. 63: 530-539. 1929.)

Of those species which occur both in these small streams and in the large rivers of Illinois the average size is much less in the small streams. Such size differences among the suckers and red-horses are obviously: due to migration, since these fishes ascend the small streams and spawn and then clescend. Size rlifferences may also he due to slower growth or greater relative elimination in the small streams. In any case it seems probable that the ammual "turn-over" in fish flesh is greater in these snall streams than in the larger rivers.

Eight of the thirteen families of fishes in Champaign County are represented by single species. The remaining five families are represented by species as follows: Catfishes 8 , Suckers 12, Sunfishes 11. Darters 12. Ninnows 23. In point of weight the sucker family (Catostomidae) takes first place, fumishing somewhat more than half of the total weight of fishes taken. Alout three-fourths of this total weight of the sucker family was contributed by the common, or black. sucker. Catostomus commersomii, which averaged 3 ounces in weight. In point of numbers of individuals the mimow family (Cyprinidae) excels. contributing $23,3+7$ of the total of 28,905 specimens taken. Of the 23 species of minnows taken, the following 9 species furnished 22.492 specimens.

\section{Campostoma anomalum \\ Pincphalcs notatus \\ Scmotilus atromaculatus \\ Notrotis blcminus \\ Notropis athipplii}

Notropis cormutus
Votropis mmbatilis atripes
Evicumba buccata
Hytopsis kentuckicmsis

Most of these are headwater species, generalized, hoth plyssiologically: and morphologically, and will be discussed more fully later:

To illustrate the wide range of abundance, one species is represented by 6,440 specimens in one season's collecting. while 12 others are represented by single specimens each. Such differences in abundance of the various species as we find in this stucly are not satisfactorily explained by one or a few factors, and it seems that an adequate explanation will involve not only a complete and intimate knowledge of all the variable factors of the physical enviromment lut-what is more difficult-an equally complete and intimate knowledge of the fishes themselves and of their varions responses to the enviromment. Any factor is important to the extent in which it limits the life and abmolance of any kind of fish. And, as a corollary, all factors are important at least as they exceed certain threshold limits.

Consiclerable information and olservation on individual species, together with the (fuantitative data, make possible a rather critical analysis of some of the factors affecting fish distribution and abundance. Enviromental factors known to he of importance in these small streams are: volume of water: (lepth of stream: rate of flow: permanency of stream ( $i$. c.. whether or not it is reduced to pools in dry weather) : suhmerged regetation, shade, and other cover : lind of hottom: temperature 
variation: fertility of soil of drainage basin; pollution; and catastrophe (unknown factors which destroy or drive out whole species from within one or mure stream systems). Biological factors known to be of inportance are: migration, activity in winter (metabolism), morphological adaptation, physiological adaptation, diet, size, hahit (e.g., sedentary or active). disease, introduction of new kinds, association of species independent of the environment, association of species showing preference for same environment, predator-prey relationslip, and modern and primitive groups.

\section{Relation of Distriblotion and Abundance to Strean Size}

All of the kinds of fishes with which we are dealing exhibit frequencies which vary with stream size in a very consistent and definite manner for each species. Small streams flowing into large streams have no nore large-stream fishes than do small streams that increase slowly over many miles of length. It can be shown that some species which reach greatest numbers at certain points in a stream also reach greatest numbers in other streans at points with the same drainage area, without reference to distance from headwaters or from the moth. In certain species the entire population is confined to a certain stream size with very narrow limits, while other kinds may occur in all sizes of streans but show ahtundances which fuctuate about a certain stream size as a morle. The young of some of the species of suckers have their greatest frequency in smaller streams than do the adults. In most fishes, other than the stickers, both the young and the adults occur most abundantly in the same size of strean.

Forlues and Richardson (1909) expressed the relation of stream size to the distribution of the different species by the relative frequency of occurrence in larger rivers, smaller rivers, and creeks. In their system of classification all of the streams of Champaign County would probably come under the general heading of creeks. Hankinson" used a similar method. Shelford ${ }^{7}$, in considering this same subject of distribution of fishes in streams, has brought out most of the principal facts of the problem. One of the more important points he states is "that the different fish conmminities are closer together in the smaller streams."

Several methods for expressing in a statistical manner this greater proximity of fish communities in the smaller streams were tried. It was found that the most satisfactory method was to consider the streams in classes in which each class is twice the preceding class, that is, in a geonetrical progression. Since the streams studied here varied in drainage area from 0.7 up to 378 square miles, they fell very conveniently into ten classes beginning with $0.5-1.0$ and ending with 256-512 square miles. The validity of this method of classification is indicated in Fig. 6 where the number of species per collection and the number of fishes per square yard have been plotted from data given in the tables mentioned on page 17. As is commonly the case, the ends of the curves are based on smaller numbers of determinations and, hence, are more vari-

6. Hankinison. T. I., "Distribution of Fish in the Streams Albout Charleston, llinois." Trans. Mil. Acäd. Sci., 6:102-113, 1913.

7. Shelford, Victor E.." "Ecological Succession. 1. Stream Fishes and the Method of Physiographic Analysis." Biol. Bul. 21:9-34, 1911. 
able. In order to smooth the curves the three classes at each extreme have been averaged and plotted, so that we now have points on the curves representing approximately equal numbers of observations. The fact that these two biological functions of stream size give curves that approximate straiglt lines is good empirical reason for assuming that this is the correct method for comparing the life of streams of widely varying sizes. There is the further convenience that the distribution of the collections in the different size classes is fairly uniform: whereas. it ten arithmetical classes of $0-40,40-80,80-120$. ctc., had been used, more than two-thirds of the total number of observations would have fallen in the $0-40$ class. It seens that this method of tabulation may be advantageously extended in biological studies to compare the range of arlaptability of different species to different stream sizes, varying from the smallest we have mentioned here up to. let us say, the size of the Mississippi at New Orleans. If, for example, we find that the sponbill cat

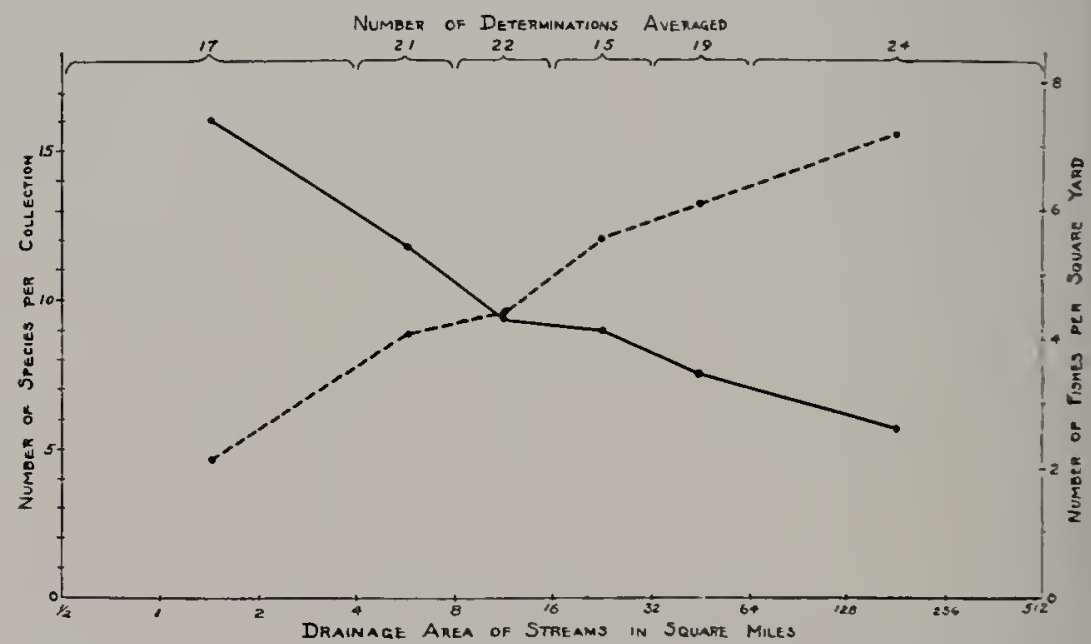

Fig. 6. Graph showing relation of variety and abundance of fishes 10 stream size. The solid line indicates number of fishes per square yard, and the dotted line number of species per collection.

inhabits streans of sizes varying over 8 size classics in this scale ( $\because . q$. from the Mississippi at New Orlcans up to Sterling on the Rock River in Illinois) and that the rambow darter likewise ranges over $\&$ sizc classes (c.g., in the headwaters of the Sangamon River in Champaisn Comnty) we may say that they have the same range of adaptability to stream size. even thotgh the total range of the spoombill cat is over two thousand miles of river and that of the rainbow clarter is mly twenty miles of creek.

In Tables I to VIII are given the frequencies of the different fishes taken in the 1928 collections in avernge numbers per 100 square yards for streams of each size. Ninctcen of these species are olviously restricted in their cistribution to certain stream systens. The average numbers per 100 square yards for these species are based only on those stream systems in which they occurred and not on the county as a whole. 
Thus, in the case of Erimy on succetta oblongus, the chtb sucker, which occurs generally in all the stream systems, there are on an average 6.0 individuals per 100 square yards in streams with $8-16$ square miles of drainage area; while in the case of Hybognathus muchulis, the silvery minnow, which is restricted to the Kaskaskia River basin, there are on an average 5.6 inclividuals per 100 square vards in streans with 8-16 square miles of drainage area and none clscallore.

Table I. SUCKERS-Average Numbers per 100 SQuare Yards.

\begin{tabular}{|c|c|c|c|c|c|c|c|c|c|c|c|}
\hline \multirow{2}{*}{ Species } & \multicolumn{6}{|c|}{ Drainage area of stream in square } & \multicolumn{5}{|c|}{ miles at point of collection } \\
\hline & 0.5 & 1 & 2 & 4 & 8 & 16 & 32 & 64 & 128 & 256 & 512 \\
\hline Erimyzon succetta obl & ongus 29. & & & 2.3 & 5.7 & 6.0 & 1.6 & 0.2 & 0.9 & 0.2 & \\
\hline Catostomus commerso & nii & & 6.6 & 1.2 & 35.7 & 9.0 & 2.2 & 7.2 & $9 . \overline{5}$ & 2.1 & 1.1 \\
\hline Catostomus nigricans & & & & & 0.1 & 0.8 & 0.7 & 1.5 & 0.4 & 1.2 & 0.6 \\
\hline Minytrema melanops & & & & & & 0.1 & & & 0.2 & 0.9 & \\
\hline Moxostona aureolum & & & & & 0.6 & & 0.1 & 0.4 & 1.7 & 4.5 & 1.2 \\
\hline Moxostoma breviceps & & & & & & & 0.1 & 0.2 & 0.1 & 0.2 & 0.1 \\
\hline Carpiodes velifer & & & & & & & 9.5 & 01 & 0.2 & 0.4 & 0.3 \\
\hline Carpiodes difformis & & & & & & & & & 0.9 & 1.1 & 0.2 \\
\hline Ictiobus urus & & & & & & & & & & 0.1 & \\
\hline Ictiobus cyprinella & & & & & & & & & & & 0.1 \\
\hline
\end{tabular}

Tabi.e II. MUD-EATING MINNOIVS-Average Numbers per 100 SQUARE Yarns.

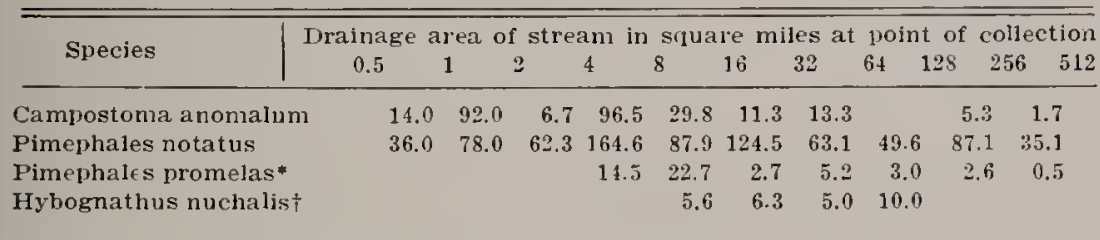

- Restricted to Sangamon River Basin.

† Restricted to Kaskaskia Rivel Basin.

Table III. MiNNows of the genUS nOtropis-Average Numibers per 100 SQLuRE Yards.

\begin{tabular}{|c|c|c|c|c|c|c|c|c|c|c|}
\hline \multirow{2}{*}{ Species } & \multirow{2}{*}{$\begin{array}{c}\text { Drainage } \\
0.5\end{array}$} & \multicolumn{2}{|c|}{ area of strean } & \multicolumn{2}{|c|}{$m$ in square } & \multicolumn{5}{|c|}{ e miles at point or collection } \\
\hline & & 2 & 4 & 8 & & 16 & 32 & $64 \quad 12 s$ & 256 & 512 \\
\hline N. cornutus* & & 10.0 & 25.0 & 88.8 & 64.3 & 132.6 & 6141.0 & $\begin{array}{ll}0 & 31.7\end{array}$ & 35.8 & 10.8 \\
\hline N. whipplii & & 4.0 & 1.1 & 8.1 & 2.3 & 20.1 & 7.9 & $9 \quad 12.1$ & 50.5 & 54.3 \\
\hline N. hlennius & & 2.0 & & 1.5 & 2.5 & 14.0 & 57.7 & $7 \quad 18.7$ & 28.9 & 21.7 \\
\hline N. umbratilis atripes & & & & 24.5 & 6.8 & 15.3 & 17.6 & f) 16.4 & 18.9 & 5.8 \\
\hline న. pilsbryi & & & & & 0.7 & 1.1 & & & & \\
\hline N. gilberti† & & & & & & 1.3 & 5.0 & & & 2.8 \\
\hline N. atherinoides-var. $\ddagger$ & & & & & & & & & 9.0 & \\
\hline N. illecebrosus & & & & & & & & & 3.8 & \\
\hline N. cayuga & & & & & & & & & 0.1 & \\
\hline
\end{tabular}

- Restricted to Sangamon, Middle Fork, and Kaskaskia River Basins.

* Restricted to Sangamon River Basin.

$\ddagger$ Restricted to Middle Fork River Basin.

Restricted to Mialle Fork River Basin. 
TABLE IV. OTHER MINNOWS AND THE CARP-AVerage NLMBERS PER IOO SQUARE YaRDS.

\begin{tabular}{|c|c|c|c|c|c|c|c|c|c|c|c|c|}
\hline \multirow{2}{*}{ Species } & \multicolumn{12}{|c|}{ square miles at point of collection } \\
\hline & & 0.5 & & 1 & 2 & 4 & 8 & 16 & 32 & 64 & 29 & 512 \\
\hline \multicolumn{2}{|c|}{ Semotilus atromaculatus } & 562 & 2.41 & 177.0 & 54.0 & 69.2 & 142.7 & 30.3 & 19.4 & 4.3 & 3.3 & 9.3 \\
\hline \multicolumn{2}{|c|}{ Ericymba buccata } & & 2.05 & 510.0 & & 58.4 & 82.4 & 100.0 & 71.4 & 37.3 & 33.2 & 12.6 \\
\hline \multicolumn{2}{|c|}{ Abramis crysoleucas } & & ¿.0 & 1.0 & 7.6 & 11.1 & $0 . i$ & 5.6 & 4.7 & 5.3 & 5.0 & \\
\hline \multicolumn{2}{|c|}{ Hybopsis kentuckiensis* } & & & & 4.5 & 2.0 & 46.9 & 74.1 & 33.6 & 11.3 & 17.6 & 9.2 \\
\hline \multicolumn{2}{|c|}{ Phenacobius mirabilis } & & & & & $0 . \overline{2}$ & 0.1 & 1.3 & 2.4 & 1.6 & 2.2 & 1.7 \\
\hline \multicolumn{2}{|c|}{ Hybopsis amblops $\bar{\varphi}$} & & & & & & 0.1 & 0.5 & 0.2 & 4.4 & 2.4 & \\
\hline \multicolumn{2}{|c|}{ Opsopoeodus emiliae } & & & & & & 0.1 & & & & & \\
\hline \multicolumn{2}{|c|}{ Cyprinus carpio } & & & & & & & & 0.1 & 0.2 & 0.2 & 0.4 \\
\hline \multicolumn{2}{|c|}{ Cliola vigilax $\ddagger$} & & & & & & & & & 4.7 & 0.4 & 0.7 \\
\hline
\end{tabular}

* Restricted to Sangamon, Middle Fork, and Kaskaskia River Basins.

$\dagger$ Restricted to Middle Fork, Salt Fork, and Embarrass River Basins.

$\ddagger$ Restricted to Sangamon and Salt Fork River Basins.

Table V. CATfishes-Average Numbers per 100 Square Yards.

\begin{tabular}{|c|c|c|c|c|c|c|c|c|c|c|}
\hline \multirow{2}{*}{ Species } & \multicolumn{10}{|c|}{ Drainage area of stream in square miles at point of collection } \\
\hline & 0.5 & 2 & 4 & 8 & 16. & 32 & $64 \quad 12$ & 28 & 256 & 512 \\
\hline Ameiurus melas & 750.0 & & 22.3 & 0.1 & 0.6 & 0.1 & 0.2 & 0.2 & & 0.1 \\
\hline Ameiurus natalis & & & 0.4 & 0.7 & 0.9 & 0.1 & & 0.3 & & \\
\hline Schilbeodes gyrinus* & & & 0.2 & 0.6 & & 1.2 & & 0.2 & & 0.2 \\
\hline Schilbeodes miurust & & & & & & 9.8 & & & & \\
\hline Ictalurus punctatus & & & & & & 0.2 & & 0.6 & & 0.2 \\
\hline Noturus flavus & & & & & & & & 1.0 & & 0.1 \\
\hline Schilbeodes exilis & & & & & & & & 0.1 & & 0.2 \\
\hline Leptops olivar's & & & & & & & & & & + \\
\hline
\end{tabular}

* Restricted to Salt Fork River Basin.

$\div$ Restricted to Salt Fork liver Basin.

TAble Vi. SUNFishes AND BASSES-Average Numbers per 100 SQUARE YaRDS.

\begin{tabular}{|c|c|c|c|c|c|c|c|c|c|c|c|}
\hline \multirow{2}{*}{ Species } & \multicolumn{2}{|c|}{ Drainage area } & \multirow{2}{*}{\multicolumn{2}{|c|}{ of strean }} & \multicolumn{7}{|c|}{ m in square miles at point of collection } \\
\hline & 0.5 & 1 & 2 & & 4 & $s$ & 16 & 32 & 125 & 256 & $\begin{array}{l}6 \\
\mathbf{5 1 2}\end{array}$ \\
\hline Lepomis megalotis & 12 & & & & 2.3 & 1.1 & 2.2 & 1.0 & 2.8 & 2.7 & 0.4 \\
\hline Lepomis cyanellus & 5. & & 5.0 & 0.3 & 3.5 & 2.7 & 1.6 & 0.7 & 0.2 & 0.5 & 0.8 \\
\hline Lepom is humilis* & & & 1.2 & & 0.7 & 0.2 & & 0.7 & 2.2 & 1.3 & 0.1 \\
\hline Micropterus salmoides & & & & & 0.4 & & & & & 0.2 & \\
\hline Mieropterus dolomieu & & & & & & & 0.2 & 1.0 & & 0.5 & 0.4 \\
\hline Amhloplites rupest is & & & & & & & & 0.1 & & 0.1 & \\
\hline Pomoxis annularis & & & & & & & & 0.1 & & 0.1 & \\
\hline Pomoxis sparoides & & & & & & & & & & 0.2 & 0.2 \\
\hline Chapnobryttus gulosus & & & & & & & & + & & & \\
\hline Lepomis miniatus $\dagger$ & & & & & & & & + & & & \\
\hline Lepomis pallidust & & & & & & & & + & & & \\
\hline
\end{tabular}

* Restricted to Sangamon, Middle Fork, and Salt Fork River Basins.

† Single specimens of these three species were taken in the Salt Fork near the outlet of Crystal lake from which they apparently have escaped. 
Table Vil. Darters-Average Number per I00 Square Yards.

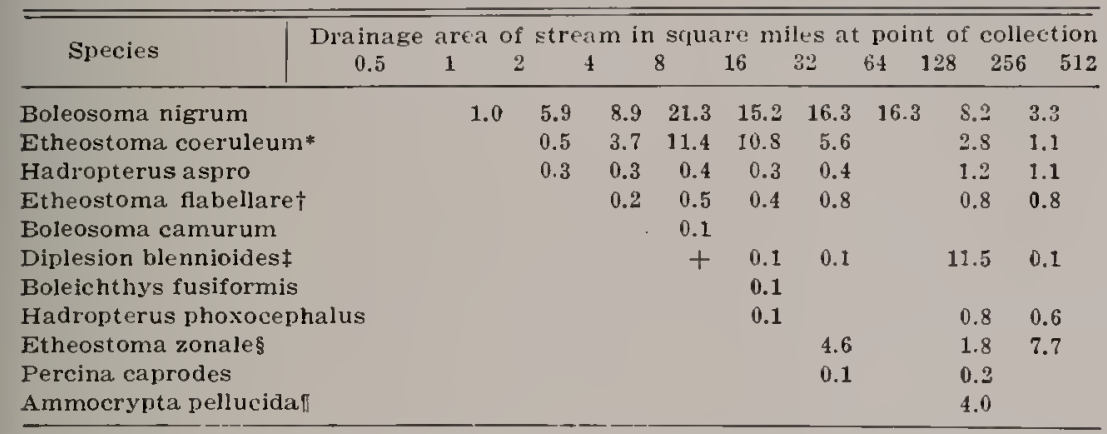

*Restricted to Sangamon, Middle Fork, Salt Fork, Little Vermilion, and Embarrass River Basins.

$\dagger$ Restricted to Sangamon, Middle Fork, Salt Fork, and Embarrass River Basins.

$\ddagger$ Restricted to Middle Fork, Salt Fork, and Embarrass River Basins.

\$ Restricted to Sangamon River Basin.

If Restricted to Middle Fork River Basin.

Table VIII. MISCELlaneOUS FISHES-Average Numbers per 100 SQUARE. Yards.

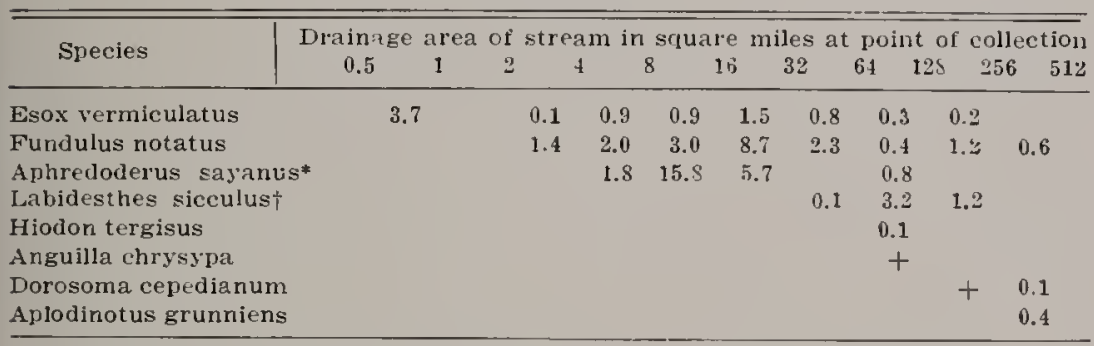

* Restricted to Sangamon, Embarrass, and Kaskaskia River Basins.

$\dagger$ Restricted to the Salt Fork River Basin.

While each species seems to present a separate and often complex problem with regard to the precise effects of stream size on its distribution and abundance, the data make clear some relationships that are important to at least several species in common. Let it suffice, here, to state only a few of these: (1) The upstream limit for alout one-third of the 74 species known in the county is the point above which a stream is reduced to a series of more or less shrunken pools during dry weather. At this point the drainage area of our streams commonly varies between 2 and 16 square miles, depending on the contour of the land, the character of the soil, and the drainage improvements. (2) Many species that habitually hide in sulbmerged coarse aquatic vegetation, even though they show no marked preference for certain species of plants, are nevertheless limited to the distribution of the plants, which is likewise a function of stream size and physingraphy. (3) Certain darters and stone cats are limited to certain characteristic kinds of rocks for cover and to certain stream velocities and depths which are found only in streams dis- 
charging certain volumes of water. (4) The kinds and proportions of food available to fishes in streams of rlifferent sizes vary widely, and there are parallel variations in the distribution of many fishes which are restricted to certain food materials.

As shown in Figure 6 (page +2 ), the number of species of fishes per collection increases downstream. In one way this may seem to contradict Shelford's general statement that "communities" are closer together in small streams than in large ones, lut it is explicable on the basis that the comparatively few species in the headwaters are generalized fishes, alsle to live and thrive under widely varying conditions. ( $\perp$ tuller discussion of these headwater fishes is given in the following section.) Then, too, the plurality of species downstream is largely due to species present in small numbers, except locally, in "niches" in the "mosaic" of the aquatic environment, where they find food and shelter without competition or invasion by larger. more numerous, or more generally distributed kinds.

The graph in Figure 6 also shows that the actual number of fishes for unit arca decreases downstream. But with this decrease of number of fishes downstream there is a corresponding increase in the average size of the individuals, so that, other factors being equal. the total amount of fish flesh per unit area is probably almost constant. This apparent constancy of the amount of fish flesh per unit area is a fact of practical importance and is readily applicable to many fisheries problems. but it is also not without its philosophical interest. The life of streams is ultimately marle up of rain water and non-living nutritive substances rlerived from the soil. This prospectively-living material is "crystallized out" in the form of lacteria and other lower forms of plant lite, very much as a salt is crystallized out of a supersaturated solution when the process is started by the addition of a crystal of the salt: and this "crystallization" goes on until an equilibrim is established. The hacteria and other lower forms of plant life which are nonrished by non-living material are the begimning of a long chain of organisms. each feeding on the one before, and their interrelations approaching an equilibrium. Fishes commonly are the end of this food chain in water. The efficiency with which cach stage in the chain utilizes the preceding one varies wide1y. The bacteria and other lower forms of plant life probalsly are efticient in utilizing non-living nutritive material, and they in turn are apparently utilized efficiently by the common plankton organisms, hut heyond this point a discrepancy arises. Some determinations made hy Mr. R. E. Richarclson, on the relation of the fish vield of Rock River to the yield of plankton there, have showed that the fish yield represented the efficient utilization of only a fraction of one per cent of the avalable plankton, although comparison of careful and detailed quantitative determinations of the vield of the small bottom animals mpon which most fishes feed with the yield of fishes shows no large discrepancy. The greatest ineficiency, or discrepancy, is undoubtedly hetween the plankton and the small lontom animals. For the latter can take only such plankten as comes to them on the bottom: they cannot forage in the plankton-laden water flowing ly overhead. Obvionsly: what is needed to make our streans more productive in fish is a new link in the food chain between plankton and the small bottom invertebrates. 


\section{HeAdWATER Fisiles}

A few kinds of fishes can withstand the rigorons conditions of extreme headwaters, but these few species are alundant in numbers of individuals. These species are:

Erimyzon succtla oblongus-Chub sucker Calostomus commorsonii--Common sucker Campostoma anomalum--Dough-belly

Pincflales notatus-Blumt-nosed minnow Scmotilus atromaculatus-Horned dace Ericymba buccata-Silver-mouthed minnow Alvamis crysolencas-Golden shiner Amciurus miclas-Black bullhead

These fishes must withstand water temperatures in summer up to and exceeding $90^{\circ} \mathrm{F}$. while living in pools so shrumken that the fish population is more than 10 times ordinary concentrations. In summer and early autumm they must withstand wide daily variations in temperature. In winter their ambient nedim is largely converted into ice. In both winter and summer they may be called upon to endure lack of oxygen, excess of carbon dioxide, or extremes in hydrogen-ion concentration. At any season there may be torrential rains or sudden thaws that can in a single hour change their enviromment from a hot, stagnant pool or icecovered ditch to a flood of muddy trash-laden water or a temporary pond in a field. Trhen the water subsides, all the old landmarks may be gone, or the channel may have been shifted or filled up or cut deeper. Most other fishes. if called upon to meet such a crisis in the dead of winter with the water temperature at freezing, would be so torpid and sluggish in their movements that they woukd either be washed tail-first downstream or else be left stranded in some cornfield when the flood subsided.

The supply of animal food for headwater fishes is probably haphazard at best and depends largely on terrestrial insects which fall into the water in summer and on worms, insect larvae, etc., washed in by rains. In headwaters plankton has not had time to develop and very few linds and scanty numbers of invertelorates are apparently able to withstand the conditions. All of these fishes seem to have solved the food question by having a very generalized diet. They all eat vegetation, organic debris, or bottom ooze probably as occasion demands, and animal food when they can get it, for none of them will refuse a bit of worm in an aquarium or on a tiny hook.

These are generalized fishes, apparently capable of meeting all situations and reaching large numbers under conditions more rigorous than others can enchre. They are generalized morpholugically and have a wide range of physiological adaptability. They are found over a wicler range of freshwater habitats than other fishes. They not only tolerate pollution but in sizalole streams can reach large numbers to the exclusion of other species where pollution is morlerate.

Morphological adaptation, degree of isolation, tolerance to pollution, and other phases of the hiology of these fishes are discussect in other sections of this paper. 


\section{Relation of Soll Fertility to Growth AND ABUNDANCE OF Fishes}

This sturly was undertaken and carried on with the rather well founded assumption that the streams of Champaign County offer an unusual degree of uniformity of conditions. The data on abundance and size of fishes, however, show a wide divergence between Spoon Kiver, or the East Branch of the Salt Fork, and the rest of the county. The greater concentration of fishes found in Spoon River was not due to a lower stage of water there than in the other streams: for all of the 16 collections in this stream were made at about an arerage stage of water and were distributed as follows: 5 in July, $t$ in August. and 7 in September. The total area covered in these collections was 817 square yards, about 8 percent of the total area covered in our quantitative collections throughout the county. The number of fishes taken from these 817 square yards was 4.566 , or more than 5 per square yard as against the average of 3 fishes per sruare vard for the whole county. Thus, on an average, fishes were twice as numerous here as in the county as a whole. Again, the total weight of the fishes taken from this stream was about 110 pounds, or 37 percent of the total weight taken in the county, although the number of individuals was only 16 percent of the total mimber taken. That is, the individual fishes averaged from 2 to 3 times as heavy here as in the county as a whole. A comparison of the average number of fishes per 100 square yards at various points on the East Branch of the Salt Fork and its tributaries with average numbers at similn points for the county as a whole (except the polluted part of the Salt Fork, where fishes are very scanty) is shown in Table IX.

The 34 species taken in the East Branch of the Salt Fork constitute a list somewhat longer than from similar numbers of collections in other streams of the same size-range in the county. The greater number of specimens taken scems to account satisfactorily for the longer list of species. A comparison of the average number of species per collection in this stream and in the comnty as a whole is siven in Tahle $\mathbf{X}$.

It is interesting to see to what extent each of the different species contributed to the increased number and size of fishes in this area. Oit the 34 species found in this stream, 25 occurred in abundances greater than the average for the county as a whole, and 20 of the latter in alundances greater than twice the average for the county as a whole. The silver-mouthed minnow, Ericymla buccata, exhihited the greatest mumerical preponderance over the average for the county. contributing 1.480 of the 3.519 specimens of this species taken in the county. This preponderance is readily explained hy its preference for a sandy hotton. of which this stream has much larger areas than are to he found elsewhere. The homed dace. Scmotilus atromaculatus, here furnished 940 out of its total 2.873 taken in the county, and the Johnny darter. Folossoma camminm, 309 out of 993 . It slotild he noted that none of the species of Notropis were more abundant here than the average for the county. at large.

The increase of the total weight of fishes in this stream is even more notable than the increase in numbers, heing 4 to 5 times the aver- 
age for the county as a whole. The greatest increase in this weight was shown by the black sucker, Catostomnts commersonii, which was not only $3 \%$ times ats alumdant here as in the county at large, hut also averaged about three times as large individually. The average size of a number of other species is obviously greater than in other streams.

The larger number and the larger size of fishes in this area indicate that the conditions for survival and srowth are more favorable here, and it seens most probable that an increased food supply is the cause. An examination of the stomach contents of a number of the black suckers, Catostomus commersonii, showed quantities of blackish mud and

Tabre IX. Abundance of Fishes in Reration to Soll Fertiliti:

(Numbers per 100 square yards of water)

\begin{tabular}{l|l|c|c|c}
\hline \hline $\begin{array}{c}\text { Stream size } \\
\text { (drainage } \\
\text { area in } \\
\text { sq. mi.). }\end{array}$ & $\begin{array}{c}\text { Number of } \\
\text { collections. }\end{array}$ & $\begin{array}{c}\text { Average of all } \\
\text { Champaign } \\
\text { lections except } \\
\text { polluted part } \\
\text { of Salt Fork. }\end{array}$ & $\begin{array}{c}\text { Average of } \\
\text { collections in } \\
\text { polluted part } \\
\text { of Salt Fork } \\
\text { (Disposal Plant } \\
\text { to County } \\
\text { Line). }\end{array}$ & $\begin{array}{c}\text { Average of } \\
\text { collections in } \\
\text { East Branch } \\
\text { of the Salt }\end{array}$ \\
$\begin{array}{c}\text { Fork where } \\
\text { the soil is } \\
\text { very fertile. }\end{array}$ \\
\hline
\end{tabular}

$\begin{array}{rrrrr}0.5 & 1419 & \\ 1 \\ 2 \\ 4 \\ 8\end{array}$

- Two collections taken in this region give an average of 238 m. 100 si. yds. They are omitted hecause $92 \%$ of this number ame of thro tolemint hadwater species which were evidently feeding here on an immpnse growth of diatoms and hluegreen algae which extended from the mouth of the last Brunrh downstream for ahout five miles. Sixty-two per cent of the total number making up these two collections were taken at a single dip of the net in a small der hol away from the main channel.

† This number is hased on four collections made from Sidney down to the county Line, but roes not include a collection madt just bilow the Homer Dan, with" 254 jer hundred sq. vels., whirh would have hrought the averige up to

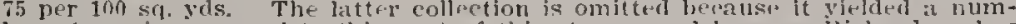
ber of species urusual to this wart of this strim and because lichardson has shown that swift water offers um usual protection to othrowise sensitive forms. 
ooze and little else. In this stream there were considerable amounts of a variety of aquatic vegetation, perhaps no greater than are to he found in other parts of the Salt Fork or in other streams. but of kinds leetter adapted for supporting an abundance of animal foorl for fishes. Collections of the small bottom animals, while not quantitative, inclicated a much larger supply of fish food.

An inquiry addressed to Mr. E. A. Norton, of the Soil Survey. brought the information that the soil of this region was unusually fertile in plant foods, produced superior crop yields, and lad a very different history from soils in the remainder of the county. This has been discussed earlier (page 7 ).

The abundance of fishes in this stream is apparently reflected in the fact that we took more adult snapping turtles. Chelvdra serpcutina. in this stream than in all the rest of the county combined. This is significant because the snapping turtle is almost. if not entirely. piscivorous in its habit.

Champaign County is near the center of an arca of several commties in which the soil is more fertile than in other parts of the state. This area, as outlined by Mr. Norton, is shown in Figure 2. From it streans flow outward in different directions-the Kaskaskia and Embarrass to the south, the Sangamon and Mackinaw to the west. the Vermilion (a branch of the Illinois) and the Iroquois to the north, and the Big Vermilion and the Little Vermilion (branches of the IVabash) to the east. A casual examination of the distribution maps of Illinois fishes as given in the atlas accompanying the volume by Forbes and Ricluardson (1909) shows a decided preponderance of occurrences in this fertile area. A small part of this preponderance may conceivably be explained by greater numbers of collections in this area, but even so the occurrences are still more numerous in this area. Moreover. as we have just secn earlier in this section, if the number of occurrences is greater, the actual number and size of fishes is greater still. It is interesting to note that the 25 species of fishes which occurred in the East Branch of the Salt Fork in numbers greater than the average for the connty are the same specios which show unusually high percentages of occurrences in this unusually. fertile general area as comprared to the figures for the state as a whole.

\section{Effects of Pollétion on Grontit. Distribltion, and Artinasce of Fisiles}

When this study was hegun it was known in a general way, from casual collecting during the past ten years, that certain streans ini Clianpaign County carried pollution and that aquatic life in these streans was more or less completely altered thereby. Previous experience in aquatic work outside the county had shown that household sewage, within certain limits, acts as a fertilizer and increases the productivity of a stream. the fishes being of greater size, alundance, and variety-a result con1parahle to the effect of ligh fertility of soil just describerl in the Fast Branch of the Salt Fork. The present studly shows that an excess of sewage results in decreases of number of kinds. aluminlance per unit area. and average size of fishes. There is no lack of fertility or of plant and 
animal foods for fishes in these polluted streams, but the fishes camnot tolerate the conrlitions or substances that result from the sewage or its products of decomposition.

The most obvious and most important factor limiting fish life in polluted waters is the deficiency of dissolved oxygen which occurs in certain places and under certain conditions. Some work done a few years ago on the oxygen requirements of fishes of the Illinois River ${ }^{3}$ showed that the number and varicty of linds of fishes taken by certain uniform methods of fishing in the same area varied directly with the amount of oxygen dissolved in the water. Furthermore, this variation in relative abundance and number of kinds not only took place in response to variations in the oxygen concentration near the lethal limit but was, apparently, equally as effective near the saturation point of atmospheric oxygen in water.

It is obvious that the size of fishes in these, as well as in other small polluted streams, averages distinctly smaller than in clean streams.

Table X. Average Numbers of Species of Fishes per Collection.

(The average number of individuals per collection was about 220.)

\begin{tabular}{c|c|c|c|c}
\hline $\begin{array}{c}\text { Stream Size } \\
\text { (drainage } \\
\text { area in } \\
\text { square } \\
\text { miles). }\end{array}$ & $\begin{array}{c}\text { Average of all } \\
\text { collections } \\
\text { except pol- } \\
\text { collections. }\end{array}$ & $\begin{array}{c}\text { Average of } \\
\text { polluted part } \\
\text { of Salt Fork } \\
\text { of Salt } \\
\text { Fork River. }\end{array}$ & $\begin{array}{c}\text { Plant to } \\
\text { County Line). }\end{array}$ & $\begin{array}{c}\text { Average of } \\
\text { Eat Branch } \\
\text { where the soil } \\
\text { is very fertile. }\end{array}$ \\
\hline
\end{tabular}

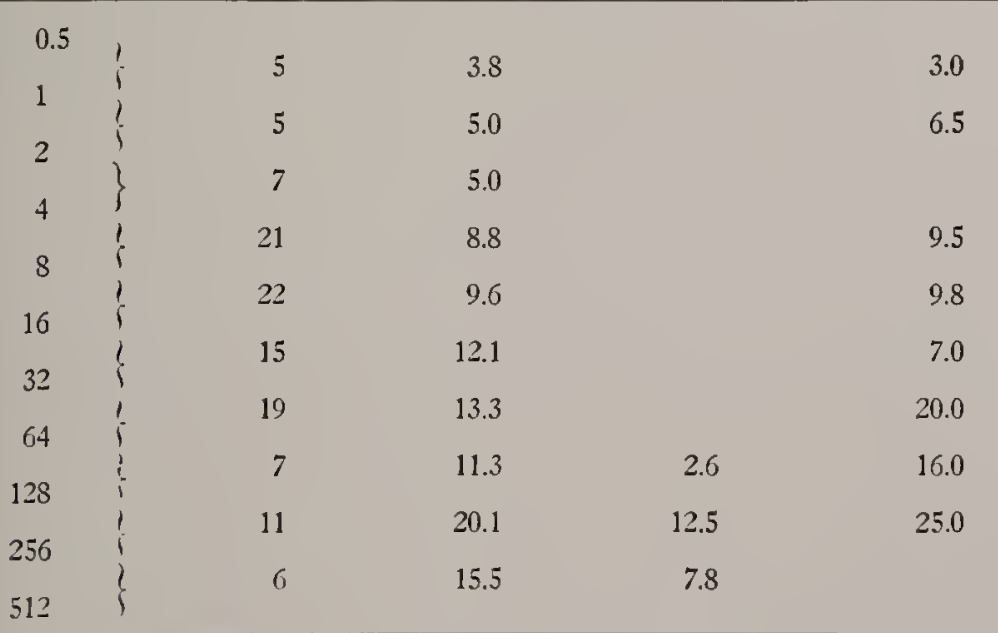

8. Thompson. David H. "Some Observations on the Oxygen liequirements of Fisbes in the Illinois river" Ill. Nat. Hist. Surv, Eul., vol. 15 (art. 7), pp. $423-437$. 1925. 
In the Illinois River it has been shown that the carp average smaller in the more polluted sections, ${ }^{9}$ and this difference in size was found to be due to slower growth of the carp in those seetions. In Champaign County streams, however, there is no evidence that the difference in size is due to slower growth; it seems somewhat more probahle that the larger fishes are eliminated loy low oxygen concentrations. since they have a smaller ratio of respiratory surface to loody size than do small fishes.

The Salt Fork, which carries wastes fron Lrbana and Clıanpaign, the largest towns in the county. is olviously polluted over a greater distance, and affords more complete information on the relation of pollution to fishes, than other streams in the county:

For comparison of the polluted and unpoliuted sections of the 17 est Branch of the Salt Fork, collections were made, at first, from approximately equal areas above and below the source of pollution, extending from the point where the stream enters Crystal Lake Park to the bridge just south of University IVoods. In this distance the drainage area increases from 59 to 76 square miles. the difference leing due primarily to the confluence of the Boneyard. The width. clepth, rate of flow, and kind of bottom are essentially the same througliout this distance. so that the same variety of habitat is afforded above and below the source of pollution, namely: long, smoothly flowing reaches, separated by small rapids or riffles, and occasional "holes" three or more feet deep. The results of quantitative collections made from 330 and 320 square yards, respectively, above and below the source of pollution. are shown in Table XI. Other fishes known to have been taken from the stream in Crystal Lake Park during the year are indicated as " $\perp$ " in this table. Most of the fishes taken below the Champaign-Lrbana sewage disposal plant were about the mouths of two tile drains.

The differences in the fich life above and helow the outlet of the sewage disposal plant are clearly due to conditions resulting from pollution in the lower section. The stream as it runs through Crystal Lake Park and down to the mouth of the Boncyard is typical of the clean dredge ditches of this region.

On May 10, 1928, at three points $11 / 2.3$, and $51 / 2$ miles helow the outlet of the plant, where the above collections of fishes from the polluted area were made, the stream had a nauscating odor perceptihle on the bridges above the water. The stream was then quite low. ancl the weather was ordinary, warm, May weather. The rocks and other objects in the water at these three stations were covercd with grayish or brownish feathery or flocculcut growths. There was a large anount of light floceulent solid matter drifting in the water. sufficient to completely clog our seine when it was held in the current more than a tew seconds. In the quieter places aloug shore and beluind drifts and large oljects, there were deposits of hlack sludge, varying from an inch to several inches in deptli, which gave off a strongly putrescent odor when stirred up. Tubificid worns, which in numbers are characteristic of heavily polluted waters, were extrenely abundant in the mucl and sludge along the slores and also annong the gravel and sand in midstreann.

9. "lhompson, Navid H. "The Knothead cary of the Illinois River." 1ll. Xat. Hist. Surv. Bul., vol. 17 (art. 8), pr. 25is-320, with 11 the. 1928. 
On the riffles and in swift water there were considerable growths of two plants tolerant of pollution-Cladophora glomerata and Elodca canadcnsis-which, together with Potamogcton pusillus and one or two others, are characteristic of the coarse aquatic vegetation of polluted small streams of Illinois.

During the summer of 1928 there were heavy rains which largely flushed out the accumulations of sludge and organic matter from the stream bed, and the continutous operation of the clisposal plant tended to reduce further accumulations. When collections were made in September it was expected that the stream would appear cleaner and fishes more abundant, but such was not the case. One small, blunt-nosed minnow (Pimcphalcs notatus) and two very small green sunfish (Lcpomis cyancllus) were collected from a total water area of 90 square yards in the same places in which the spring collections were macke. There was no floating or drifting organic matter or sludge,

Table Xi. Effects of Pollution in the IVest Branch of the Salt Fork.

Comparison of the kinds, numbers, and maximum sizes of fishes taken from approximately equal areas of water in the West Branch of the Salt Fork above and below the source of pollution on May 10 and 11, 1928. (See text, p. 52.)

\begin{tabular}{|c|c|c|c|c|}
\hline \multirow[t]{2}{*}{ Species } & \multicolumn{2}{|c|}{$\begin{array}{l}\text { Collection from } \\
330 \text { square yards } \\
\text { above source of } \\
\text { pollution. }\end{array}$} & \multicolumn{2}{|c|}{$\begin{array}{c}\text { Collection from } \\
320 \text { square yards } \\
\text { below source of } \\
\text { pollution. }\end{array}$} \\
\hline & $\begin{array}{l}\text { Number } \\
\text { of fishes }\end{array}$ & $\begin{array}{l}\text { Max. size } \\
\text { in inches }\end{array}$ & $\begin{array}{l}\text { Number } \\
\text { of fishes }\end{array}$ & $\begin{array}{l}\text { Max. size } \\
\text { in inches }\end{array}$ \\
\hline Notropis whipplii & + & & 1 & 1.8 \\
\hline Pinephales notatus & 320 & 3.0 & 1 & 1.1 \\
\hline Senotilus atronaculatus & 22 & 6.1 & 1 & 2.0 \\
\hline Notropis umbratilis atripes & 71 & 2.5 & 18 & 2.1 \\
\hline Ericymba buccata & 126 & 2.3 & 2 & 2.0 \\
\hline Campostoma anomalum & 5 & 4.8 & & \\
\hline Abramis crysoleucas & 74 & 5.1 & & \\
\hline Erimyzon sucetta oblongus & 3 & 5.4 & & \\
\hline Catostomus commersonii & 6 & 9.8 & & \\
\hline Esox vermiculatus & 1 & 8.0 & & \\
\hline Lepomis megalotis & 12 & 4.3 & & \\
\hline Lepomis cyanellus & 7 & 5.1 & & \\
\hline Lepomis humilis & 3 & 2.3 & & \\
\hline Lcpomis pallidus & 1 & 4.6 & & \\
\hline Boleosona nigrum & 6 & 1.2 & & \\
\hline Notropis blennius & + & & & \\
\hline Ameiurus melas & + & & & \\
\hline Labidesthes sicculus & + & & & \\
\hline I.cpomis miniatus & + & & & \\
\hline Ethenstoma flabellare & + & & & \\
\hline
\end{tabular}


such as was seen on May 10, and no large beds of sludge. lout the sand and the mud of the bottom and banks contained a large admixture of black sludge with a putrescent orlor and mmense numbers of tubificid worms. The stream gave off the same nauseating odor as was noticed in May. The water was umsually clear for a stream in this region, possibly from the lack of fishes that tend to stir up the serliment and bottom muds, or else because of the agglutination and precipitation of the silt by the abundance of microscopic organisms poured in by the disposal plant. Downstrcam from the disposal plant outlet to a point several miles lelow St. Joseph, there was a heavy growth of brown diatoms : and for several miles below the confluence of the East Branch of the Salt Fork, there werc heary growths of blue-green algae along with the diatoms.

Collections made in September, 1928. from the 11 est Branch and the East Branch, at stations $11 / 2$ miles abore their confuence. rie'ded in the West Branch 30 fishes, taken from about 105 square yircls. all of them belonging to four known tolerant kinds and having a total weight of about three ounces-as against 437 fishes, of 25 kinds. taken from 90 square yards in the East Branch and having a total weight of about 15 pounds.

In January, 1926, when the sewage disposal plant had been in operation about a year, a collection of fishes was made in the ITest Branch of the Salt Fork at the bridge just south of University Moods at the same place where the collections were made in the spring and fall of 1928. At this time fishes were clearly more numerous than they were found at any time in 1928. The number of kinds and the maximum size were grcater, and specimens were taken of the Jolnmy darter, a species that has not been found since in the polluted section of the West Branch, although it is more tolerant than other darters. The 1926 clata, though fragmentary, at least make it clear that four years of operation of the sewage disposal plant have had no greater effect than one year in cleaning up the stream. ${ }^{10}$

Dr. T. H. Frison reports that, in the years 1912 to 1914 , sunfish. builheads, and suckers could be taken in fair numbers on hook and line from the West Branch of the Salt Fork near the University Moods.

Collections made by the Natural History Survey in the liest Branch of the Salt Fork in the period 1882-1901 showed a number of species not found in the 1928 collections, even thongh the latter collections were twice as mumerous. In the older collections the white crappie and the large-mouth black bass were taken, probably because they were plauted or had escaped from a fish hatchery which was then in operation in Urbana. Besides these. the spotted sucker, common red-horsc. suschermouthed minnow, top minnow, brook silverside, and black-sided darter have since disappeared, even from the stream above the source of pollution. It so happens that the stream ahowe the source of pollution is just at the upper limit of stream size in which all of them live. except perhaps the last named: and since the stream below Urbana has hecome heavily polluted, they apparcntly have not been able to exist and mantain their limmbers cut of from the lower course of the stream.

\footnotetext{
10. In the past two years the plant has been operated continuously, anu new units have heen added which tend to reduce further the organic load of the strean. A few cursoly examinations made recently reflect these improvements, there being A few cursoly examinations made recently reflect these improvements, thers being lower course of the stream.-D. H, T. Auly 1, 1080.
} 
Collections of bottom fanna and plankton were made in the West Branch near the University Woods in May, 1929, and were identified in the laboratory by $\mathrm{Mr}$. Richardson. The bottom fanna collections were made from clumps of Elodca canadcnsis growing in midstream and from gravel and sand there. The most numerous animals taken from these were two species of sludge worms, or Tubificidae. Limnodrilus hofmeisteri and Tubifcr tubifcr, which occurred in ronghly 100 times the numbers to be expected in ordinarily clean streams with gravel and sand bottom. The presence of these sludge worms in such numbers is indicative of a heavy load of organic matter in the water and, in general, conditions which are distinctly pollutional. Small numbers of several other species of small bottom animals also occurred in these collections, but their value as indices of pollution has not been sufficiently studied. One other thing was noticed which invariably indicates foul conditionsthe larvac of the sewage fly, Psychoda altcmata. Furthermore, other insect larvac fotnd here were covered with colonial vorticellid protozoans of the genus Epistylis. In unpolluted streams the insect larvae and other snall bottom animals are habitually clean and free from incrusting microörganisms. The plankton sample taken here showed Epistylis, Thiotlurir, and Rotifer tardus, all of which were probably washed down directly from the sprinkling filter bed of the sewage disposal plant.

Determinations of the amount of dissolved oxygen in the polluted section of the Salt Fork, made at varions times cluring the past two or three years, showed amonnts varying from saturation down to 3 or 4 parts per million. In those cases where a series of samples were taken on the same clay at different points on the strean the samples showing least dissolved oxygen were taken near the ontlet of the plant. Dnplicate samples taken on January 17,1929 . at a point $11 / 2$ miles below the plant, showed a biological oxygen demand of 51 and 56 parts per million. At that time the plant was discharging at the rate of $2,700,000$ gallons per day, and the effluent was diluted to 6 times that volume by the water int the strean.

Occasional periods of oxygen deficiency are 11sually regarded as the immediate catsse of destruction of fishes ly pollution. "Evidence of this cante to hand in November, 1928, during other studies along the West Branch of the Salt Fork from the bridge east of the Tuberculosis Sanatorium down to Brownfield Woods, points respectively $1 \frac{1}{2}$ miles and 3 niles below the sewage disposal plant. In the early part of the month the stream had been low and there were considerable accumulations of sludge and putrescing organic matter along the shore and in the quieter places. On the 14 th and 15 th of Novemlier, as a restult of rains, the water level rose and the sludge and organic natter were stirred up. At this time the stream was black, smelled strongly putrescent, and had the appearance of being septic. On the $16 \mathrm{th}$ and 17 th the stream had stilysided and restumed its customary aspect. On these clays several small fishes were piclied ip freshly jead; they were faded and had their mouths agape and their opercles and branchio-stegals extended, showing evidence of suffocation. Since lack of oxygen is the only well-known means by which pollntion has its effect on fishes, it seems that lack of oxygen must be at lcast the tentative explanation of the alsence of fishes in this stream. 
The West Branch of the Salt Fork from the sewage disposal plant down to its confluence with the East Branch receives no tributaries other than a few tile drans. In this stretch of ahout 12 miles the condition obviously improves, fishes become more numerous, of more kinds, with greater maximum size; and the deposits of sludge, the nauseating odor, and the other evidences of politution decrease. It seems quite certain that this improvement in the stream without much dilution is due to the continuance and completion of biological processes of selt-purification.

A collection made in September, 1928, about 2 miles below the confluence of the East Branch and West Branch of the Salt Fork. showed fishes in normal numbers, but 98 percent of them were of known tolerant kinds, 92 percent leeing blunt-nosed minnows, silver-mouthed minnows. and steel-colored minnows, which were feeding on the very heary development of diatoms and bltie-green algae at this point. From Sidney. down to the county line, fishes occurred in about one-seventh of the numbers normal to streams of this size. Apparently normal numbers and kinds of fishes were taken just below the Homer Dan, but Richardson (1928) has shown that swift water, in general. offers musual protection to specics otherwise sensitive to pollution.

During the period 1919 to $1924 . i$. c.. before the sewage disposal plant was put in operation, the writer collected fishes from time to time in the two-nile stretch alsove the Homer Dam. Fishes taken then included green sunfish, long-eared stufish, sucliers, lullheads. and several kinds of minnows. When those collections are compared with collections made in the same place in 1928. no olvious increase in fishes is apparent, although several car-loads of fishes have been planted there since the disposal plant was put in operation. There are reports of crappies, carp, channel cat, bullheads, and many sunfish being taken ahove the Homer Dam in 1916.

The number of species of fishes and the abundance of each in the polluterl part of the Salt Fork, as compared with other streans of the county, are shown in Tables $\mathrm{IX}$ and $\mathrm{X}$.

The following list of fishes. arranged in order of decreasing tolerance to pollution in small streams. is hased on olvervations in this and other streams of comparable size:

\author{
Semotilus atromaculatus \\ Pimephales notatus \\ Notropis umbratilis atripes \\ Ericymba luccata \\ Notropis whipplii \\ Abramis crysoleucas \\ Leponis cyanellus \\ Boleosona nigrum \\ Campostoma anomalum \\ Erinyzon sucetta olslongus \\ Catostomus commersonii \\ Notropis cornutus \\ Hybopsis kentuckiensis \\ Notropis blennius
}


The darters other than the Johnny darter seem to be most sensitive to pollution. Almost all of these tolerant species find their greatest development in headwater streans. These headwater species occur in polluted large streams where they normally would not occur in such numbers were the stream clean.

The Boneyard, a small creek flowing through Champaign and Urbana and emptying into the TVest Branch of the Salt Fork alıout a halfmile above the outlet of the sewage disposal plant, has been badly polluted with a miscellany of household and industrial wastes including oils, gas liquors, tar, soap suds, rubbish, garbage, precipitates from watersoftening processes, drainage water from the streets, etc. This stream is practically without fish, there having been reported within the past few years a medium-sized black sucker, three or four very small chub suckers, and a school of about a dozen small minnows. The effect of the Boneyard water on the fishes of the stream below was not separated from the effect of the effluent of the disposal plant in the present study:

Copper Slough, a branch of the Kaskaskia, receives untreated sewage from the west part of the city of Champaign and is thereby so grossly poliuted for several ninles down from its source that there was no fisi life at all in August, 1928, and even in its lower course there were very reduced numbers of fishes. Dr. T. H. Frison reports that some years ago black bullheads and horny-head chulss could be taken where Route 10 now crosses Copper Slough.

Sewage from the village of Rantoul flows eastward about two miles in a ditch alongside the hishway and empties into the East Branch of the Salt Fork. It was noticed at the time of our first visit, in July, that the ditch coming frum the town (carrying undiluted sewage) stank badly and was black with sludge, and that grayish growths of pollutional protozoans or schizomycetes were abundant. The weather just then was very warn, and by the time the sewage had reached the stream the putrefactive processes were evidently nearly complete; for the stream below the mouth of this ditch was not septic, although there were extensive deposits of sludge and an obvious scarcity of the bottom animals ordinarily found in clean streans. Fishes were abundant in the stream below the mouth of the ditch, a quantitative collection made there showing 1.866 per 100 square yarrls-a figure which conjpares well with abundance figure for other headwater streams feeding the East Branch of the Salt Fork. It should le mentioned, however, that $9+$ per cent of the fishes in this collection were of known tolerant kinds. The same place was visited again in Novemler after the weather had been near freezing for some days. Although the water level in the ditch and in the stream was at ajproximately the same stage as in July, the coolness had retardel the putrefactive processes so that they were, apjarently, only well under way by the time the stream was reached; for the stream itself was stinking and septic and entirely without fishes for $1 \mathrm{~T} / 2$ miles below the mouth of the ditch.

A few years ago many fishes were killed in a trilutary of the Sangamon as the result of polintion ly wastes from a camning factory near Ciloson City. 


\section{Other Environiextal Factors AfFectixg \\ Distribution axd ABLidance}

Vegetation is a factor determining the abunlance of most smallstream fishes. The largest variety and greatest abundance of fishes in individual collections were consistently found in situations with iuxuriant growths of submerged coarsc aquatic plants. The large number of fishes in such places is certainly correlated with the large pupulations of food organisms which these plants support. The presence or absence of certain species, such as the pirate-perch. the golden shiner. and the grass pike, is closely assaciated with the presence or alsence of aquatic vegetation.

Depth of water is an important factor in the distribution of many fishes. The buffalo fishes, carp-suckers, gizzard shad, shcepshead, and several of the sunfishes are found only in the deeper pools. Others, such as the long-eared sunfish, may occur in a stream of any size in the county providing that the water is a foot or more in depth. In general. aduit fishes seek deeper water than young fishes, and large species more than small species.

Kind of bottom and rate of flow of streans in Illinois generally are casually related, and it is difficult to differentiate the effects of these two factors on the distribution of fishes. Some species are obviously more abundant on certain kinds of bottom than on others. and a few are very strictly linited to certain substrates, as is described in various places in this paper. Our present data do not permit a critical comparison of total abundances of fishes on different kinds of hottom, and no obvious consistent differences were apparent during the course of the field work.

\section{Effect of Fish-eatixg Species ox Abicidace}

The general decrease in mumber of fishes and increase in size of individual fishes as we pass from the smaller to the larger streams may he due, at least in part. to the larger number of fish-eating linds in the larger streams, such as the large-mouth and small-mouth black bass and the channel cat. Our numbers of these kinds are tow small to make a statistical comparison. One of the most voracions of the typically small-stream fishes is the grass pike. Excluding collections from the polluted part of the Salt Fork, onr 26 collections in which the grass pike occurred averaged 2.49 fishes per square yard: and the remaining 86 collections, in which the grass pike clid not eccur, averaged 5.71 fishes per square yard-more than twice as many. The number of grass pike producing this effect was quite small, averaging only 0.000 per square yard. This relatively large effect of so $\mathrm{few}$ grass pilie is understandalile, however, because we have açuarium experiments which show that a grass pike of average size can cat abont one minnow per day:

\section{Some Observations on Morphological Anaptatioxs}

Since the beginning of the scicnce of biology, close organic correlation of the various parts and internal functions of an organism during its life history has heen so apparent and so exact that workers in this field are much siven to teleological explanations of these phenomena. 
Workers investigating the relations of organisms to their surroundings are much more impressed by the similarity of the reactions of the different organisms in a given environment than by the similarity of morphological adaptations found there. In this they are doubtlessiy correct. Morphological adaptation, however, should not be neglected or put aside as unimportant.

Among the small-stream fishes of Champaign County it has been found that there is a readily recognizable and fairly close correspondence between habit and structural adaptation, although there are many exceptions. Non-adaptive structures, incongruities, elaborateness, and uniformity of detailed structure are certainly not necessary from the standpoint of the requirenients of the environment; nevertheless, they are the rule within the various races of animals and are intimately tied up with the fundamental nature of living sulsstance itself. The relative importance of physiological as against morphological adaptations is a dilemma that has been considerably clarified by recent findings in the study of the manner of inheritance of the characteristics of living things. It has been found that many morphological changes are insepurably assriciated with certain physiological qualities. It so happens that the morphological changes are usually of trivial importance from the standpoint of viability and usually involve such things as proportion of parts. texture, color pattern, etc. The associated physiological qualities, on the other hand, commonly involve such important things as number of eggs, length of life, rate of development, viability at all stages, reactions to stimuli, etc. If both the physiological and morphological changes are of advantage they will survive. If looth are disadvantageous they will not survive. However, if one is advantageous and the other disadvantageous the one will survive which has the greater selective value at critical points in the life history, and the other will be carried along willy-nilly because it is inseparably associated, even though it is unnecessary or even somewhat disadvantageous. The fact that hereditary changes ustally involve selective differences which are more of ten physiological than morpholegical, gives a hint as to why animals show a better physiological than morphological closeness-of-fit to the environment.

The fishes of Champaign County fall into three approximately equal groups with respect to current: (1) Those that live in the faster. shallower water and spend most of their time. not swimming, but clinging to the bottom or hidiug behind or under oljects which break the force of the current. (2) Those that live in deejer and more sluggishly moving water and spend most of their time swimming or floating but not clinging or hiding. (3) Those that inhaloit looth kinds of places and divide their time between clinging or hiding and swimming freely. As these three groups of fishes are examinerl. certain morphological features stand out as characteristic of each group.

The first group - "clinging" fishes-is typified by the hog sucker, the darters, the red horses, the stone cats, and the tarlpole cats. They have a large head and a borly that tapers from the head to the tail and is roughly circular in cross-section: that is, they are slcnderly conical. They have large pectoral fins with which they cling or "crawl" on the bottom. Their specific gravity is greater than that of other fishes. They often show protective coloration by having their lacks crossed lyy lark lars. 
The second group-" swimming" fishes-is typificd by the gizzard shad, the toothed herring, the sumfishes, and certain minnows such as Notropis cormutus, $N$. umbratilis, and $\Lambda$. alipplii. These fishes are flattened laterally and tend to taper equally toward the head and tail from the middle of the body. Their swimming halits are correlated with large caudal fins and a specific gravity almost exactly the same as water. These are the fishes that leap from the water. Adults of several other species have the body shape and swimming habit of this group, but their young live in fast water and have the body shape typical of the first group. An excellent example of such a change in body shape and habit is found in the silver carp, Can piodes aclifer.

The third group-"generalized" fishes-has a body form typified by the extreme headwater fishes, such as the blunt-nosed minnow, the horned dace, the chul sucker, and the dough-belly. These fishes tend to be circular in cross-section and to taper from the middle toward both ends. They are commonly found in both still and fast water.

While there are many exceptions in one way or another to the above classification, it still holds for most of the local fishes.

There are other local examples of structural adaptation correlated with certain habits. Fishes that regularly feed from the surface. such as the silverside (Lalidesthes sicculus) and the top mimnow (Fundulus notatus), have flat backs and upturned mouths. Larger fishes that halitually live under flat rocks, such as the stone cat (1oturus flur'us). are dorso-ventrally flattened. Fishes that nuzzle the botton and pry among rocks for food, such as the various suckers and the sucker-mouthed minnow (and elsewhere the sturgeons), have inferior, protrusible mouths. There are three species of one genus (Ictiobus) which are botton feeders but have differently formed months: the small-mouth buffalo has a strictly inferior motith, the mongrel buffalo has a mouth tilted up at about $22^{\circ}$ from the horizontal, and the red-mouth buffalo las its mouth turned up at an angle of $45^{\circ}$. In late summer large numhers of red-month buffalo have been seen sucking in the foam and floating insects in the quieter eddies of Rock River. hut never a mongrel or a small-mouth luffalo. This observation is amply borne out hy recent studies of the stonach contents of these three species.

\section{Migration, IsOLATION, AND (IAANGEs tX Distriblotion}

The extrenes of fish migration are represented ly fishes taken in Champaign Connty. As one extreme, there is the eel taken in the Embarrass River, which must have heen spawned in the Sargasso Sea off the coast of the Bermuda Islands. according to recent life-listory work on this speries. As the other extreme, we have darters that live under the rocks on riffles and may not have moved more than a few lundred yards in many generations. ${ }^{11}$ The migration of most of our species. however, is nioderate.

11. A good instance exemplifying this sedentary lahit came out during our work on the Rock River. In 1927. after four years of collecting in the Rock liver hasin, it seemed that our list of fishes was complete, at least for the basin in lllinois. I went to see two old fishermen. brothers by the name of Mcdillan. who had mate most of thelp living since horliood by fishing one way or a nother in the vicinity of Rockford. In order to facilitate conversation and avoid difficultes of different common names for the same fish and the same common nane for different fishes, I took along the Survey's illustrated volume on the fislies of Ithinois. We 
We have sufficient information to show nligration for eight species of suckers, the young of each of these species being regularly taken nuch further ttpstream than the adults. As an example, the young of the common red-horse were found most abundantly in streams draining 4 to 8 square miles, while the adults are known to reach their greatest abundance in streams draining 1.000 or more square miles, $i$. c., much larger than any in Champaign County. The toothed herring and the gizzard shad probably make migrations of abont the same order in larger streams, and the larger members of the sunfish fanily are probably capable of extended migration, although our data do not directly indicate this. Among the mimnows there are no clear examples of different distribution of the young and the adults in our streams, but a certain amotunt of migration is indicated by the fact that headwater minnows are regularly found in sp,ring in sniall rivulets which at other seasons dry up completely for one or more miles. None of our seven species of catfishes gave evidence of any considerable migrations.

During 1928 and 1929, several anglers fishing in the Sangamon River, both in Champaign County and Piatt County, have expressed surprise at taking sheepshead in fair numbers, a kind of fish which they report had not been seen in the Sangamon before. This suggestion that the sheepshead is a newcomer is substantiated by our findings. We took ten specimens in the Sanganon within the county in 1928. Earlier collections by the Survey did not take the sheepshead from the Sangamon, cither in this county or any place elsc along its entire length, although this species was taken in the Illinois River and in several other streams in the state. The specimens taken or seen in 1928 all weighed between 3 and 6 ounces-the same size, incidentally, at which the sheepshead have been observed in thousandis in May lelow dams on the Rock River and helow the head-gates of the Illinois-Mississippi Canal Feeder, attempting to go upstream. The fact that the collections and reports of sheepshead in the Sangamon in 1928 and 1929 are scattered over fifty miles or more of stream, argues that these fishes bave migrated upstream from some point fturther down, rather than that they have been planted locally in many places.

leafed through the book together, meanwhile checking the fishes they had seen in the vicinity against my suecies list for the rive. I pointed to the picture of the sculpin (Cottus ictalops) and remarked that they probably had not seen it luecause we had not taken it in our extensive program of collecting in the basin. The older brother spoke up and said, "Yes, that's a doogy pawl. 1 call it that berause it, looks like a fish by that name I used to catch when I was a boy in Scotland." He went on to relate that for many" years they har made a husiness of catching minnows for the bait market in the small streams about Rockford and that there used to he one place, and one place only, where they found the sculpin. This place was in a small stream tributary to Sarver Creek, about seven niles northpest of Rockford. They had first noticed it there some $150^{*} 20$ years previously. and they had not been to the place for the past several years The jounger brother agreed to go with us next day and point out the place. When we arrived, there was a rocks riffle about 10 feet long in a tiny stream in a pasture. TVe set our minnow net below the riffle, lolled some of the rocks ovcr, and lifted rut 3 or 4 sculpins. Then we seined just above the riffle, but got none. We seined below the riffle and took fise or six more sculpins. A few yards further down we took none. Then we went on and seined over several hundred yards but found none. Persistently we scined in the vicinity of every bridge over this whole tiny stream system, but no sculpins. For several weeks as we worked ov"r the small streams of that part of the Rock River basin. we tried every likely riffle. many of which were identical with the sculpin riffle, but nowhere did we find another sculpin. When our sculpins were compared with others of the samu specios rollected in fridiana, they were found to diffur in seriral minor dritals of body contour and minute structure. While the sculpin is in a differcnt family of fishes from the darters, it is of about the same size and in point of shape and halijt ciull lu'st be described as an cxaggerated dirter. 
There is another kind of migration that applies to all our larger fishes in Illinois streams and probably also to smaller kinds. In spring. summer, and early attumm the larger fishes are found in all parts of the larger streams; some are in fast water, some in smoothly flowing reaches, some hiding among brush and vegetation, and some in the deep pools of quiet water. As the water becomes cold with the apjroach of winter, these fishes become sluggish and stop feeding, then retreat downstream and join the fishes of the deep pools. In spring when the ice is gone and the water is warmer, they ascend the stream and begin feeding. Our investigations on Rock River have shown that the order in which the different fishes come into the quiet pools and eddies is quite definite and that the order in which they go out is the reverse of the order in which they conne in. Furthermore, those that come in first are generally sluggish-water fishes; next are those of molerate current: and last are those of the swift waters, such as the red-horses and the common sucker. In Rock River the wall-eyed pike may or may not retreat from the fast water during winter. This pike is very active in its movements all winter and feeds voracionsly and is taken on the hook in swift water every month in the year. The fishes soonest benumbed are those that live in summer in the deep pools, such as the blunt-nosed river carp, the sheepshead, the huffalo fishes, the quillback, the carp, and the gizzard slad. The last-named fish seems particularly susceptible to cold. being seriously winter-killed.

Fishes in the headwaters of the Salt Fork are but two or three miles overland from fishes in the headwaters of the Sanganon, but as a fish travels they are mote than 1,200 miles apart. Such long distances, doubtlessly, are traversed in a reasonable period of years by the larger. abler, and habitually swimming species. The uniformity in contour. color pattern, and norphological detail within such strong swimming species as the suckers and the larger sunfishes bears witness to frequent interbreeding within the species and lack of isolation. On the other hand, minnows, darters, and small species of other groups with feelle swimming powers and with a tendency to spend most of their tine in restricted habitats, such as nunder and around stones, anong vegetation or other cover, small eddies below riffles, etc., may he effectively isolated for very long periods of time, especially if they are in different streams and separated by many miles of water. Even in the same stream their distribution is "spotty" hecause they are sedentary or are adapted to limited kinds of halitat.

It may be possible, however, for some fishes to pass from one basin to another, in such flat country as we have in Champaign County, during prolonged periods of extrenely wet weather. This is indicated in the state distribution of the silver-mouthed mimow (Ericymba buccafa). That this minnow shonld pass from one basin to another is not at all surprising. since we have already shown that it is an extreme headwater species and will even ascend tile drains. The present data indicate that interbasin passing does not occur unless it be among the extreme headwater species. Among the isolated species in general, there is no evidence of any extended migration during the spawning period. 
Among families of small fishes, ichthyologists have found local races and varieties to be the rule. Among freshwater fishes commonly inhabiting headwaters and other out-of-the-way "niches" in the environment. inordinately large numbers of species and varieties of minnows and darters are recognized. While our Champaign County collections have not yet been thoronghly studied with this in view, racial differences in morphological detail have been found, as will be fully reported in a later paper. Several of these differences may be mentioned here: (1) The fan-tail darter in Champaign County is restricted to the Sangamon, Salt Fork, and Middle Fork basins. Sixteen specimens from the Sangamon and its tributaries each had 8 dorsal spines. Of 7 specimens from the East Branch of the Salt Fork, four had 8 spines and three had 7 spines. Nine specimens from the Middle Fork and its tributaries each had 7 spines. (2) The log perch taken in the Kaskaskia Basin have a color pattern distinctly different from those taken from the Middle Fork Basin. (3) The orange-spotted sunfishes of the Sangamon have a body shape which differs markedly from those of the Salt Fork. (4) Within certain small species there seem to be consistent differences in the numbers of vertel)rae between different stream systems.

A casual survey of the literature on geographical races among motile animals gives the impression that isolation is a more effective cause of racial differences within a species than is a difference in environment to which an animal may respond directly in one gencration or be gradually adapted over many generations. If this be true, the explanation of geograplical races is to be sought in terms of the properties of the germplasm and of the growth of populations rather than in terms of the response of the organism to the ellvironment. Every species that has been studied genetically has shown heritable variations of greater or less degree. Furthermore, these heritable variations are continually arising do noc'o by changes in the germplasm due to causes entirely unrelated, as far as is known, to ordinary variations in the physical environment. While most of these heritahle variations are disadvantageous to the animal and are rapidly eliminated, many of them are of indifferent selective value and may persist. Yet it is a significant fact that no heritable variations have been found which are more viable and can crowd out the "wild type." This superlative position of the "wild tvpe" suggests that it represents the highest possible combination of hereditary factors affecting viability, and if so, variations in vialility can occur only in the downward direction.

It is common experience that a population of a species is at all times heterogeneous, its degree of heterogeneity being dependent primarily on the rate of origin of variations $d c$ novo as compared with the rate of their elimination due to selectivity and the degree of inbreeding. The degree of inbreeding is important because it is a common fact of all population studies that the population of a species within an isolated area at any one time is not descended from the entire population of that species in that area, let us say several generations earlier, but from a fraction of it. If, in any generation, by chance, the parents of the next generation are all homogeneous for some indifferently selective, heritable variation which has arisen $d e$ nowo, then the character of the 
whole population will have been ehanged without regard to the selective value of the variations or environmental differences. Since these heritable changes arising $d c$ nor'o are fixed in populations by chance. the probability is infinitely small that the same changes will arise and be fixed in isolated populations. Hence, as long as populations are isolated. heritable differences from the original condition. and from each other. will accumulate. If, however. interbreeding is occasionally possille luetween partially isolated populations, their differences will tend to loe ironed out, likewise, by' chance.

Of the 74 species taken within the county, there are 17 which have been collected in sufficient numbers to avoid errors due to random sampling and which are absent from one or more of the six stream sistems. Furthermore, these 17 kinds include only those species whose friterred habitat and stream size are known to occur generally in the streams froms which they are ibsent. These species are listerl below, together with the stream systems in which they have been taken.

\section{Species}

Stream Systems

Pimephales promelas Sangamon

Hybognathus nuchalis Kaskaskia

Notropis gilberti Sangamon

Notropis atherinoides var. Middle Fork

Notropis illecebrosus. Middle Fork

Hybopsis amblops Middlc Fork, Salt Fork, Embarrass

Cliola vigilax Sangamon, Salt Fork

Schilbeodes gyrinus Salt Fork

Schilbeodes miurus Salt Fork-

Lepomis humilis Sanganon, dfiddle Fork. Sali Fork, Embarrass

Aphredoderus sayanus Sangamon, Embarrass, Kaskaskia

Labidesthes sicculus Salt Fork

Etheostoma coeruleum All but the Kaskaskia

Etheostoma flabellare Sangamon, Middle Fork, Salt Fork

Etheostoma zonale Sanganon

Diplesion blennioides

Ammocrypta pellucida Middle Fork, Salt Fork, Embarrass Middle Fork

As these fishes are examined to see what they have in common, we find, first, that they are all small, the largest specimen among them heing a Hybognathus nuchalis $3 \frac{1}{4}$ inches long. Nore than halt of them are clearly sedentary in habit and spend most of their time hiding. All of them are specialized plysiologically, since they are restricted to special kincls of halhitats which are usually of discontinuous distribution. Our fundings on these fishes corresponkl, both in geeneral and in cletail. with the data on their distribution in the state and in the connty as siven by Forhes and Richardson in "The Fishes of Illinnis," and with Hankinson's data in the "Distribution of Fish in the Streans about Charleston, Illinois." 12

12. Loc. cit. 
Since the streams of Champaign County are so similar and offer the same variety of habitats, it may be assumed that the absence of one of these species from a stream system is clue to one of two things: either that it may never have extended its range into that stream, or that it may have heen there formerly but is now alsent as a result of some catastroplie which wiped it out. Poth of these explanations are necessary to accotnit for all the data. The first applies to Diplesion blcnnioides, Notropis illecebrosus, and Schilbcodes miurus, which are strictly limited to the Wabash drainage in Illinois, and Etheostoma zonalc, Notropis gilberti, and Pimephales promelas, which are limited to the Mississippi drainage. The second explanation covers certain changes in the distribution of individtal species in the county during the period between the earlier collections of the Survey and the present ones-changes which indicate catastrophes of one kind or another: disease, an exceptionally cold winter or hot summer, pollution, predators, ctc.

The most pronounced case of increase in abundance is found in the horned clace (Scmotilus atromaculatus) in the Salt Fork. In the period 1882 to 1901 not a single specimen of this species was taken in the 25 collections of fishes made in this strean and its tributaries, but in 1928 it cccurred in 48 out of our 52 collections in the same areas, which thus contributed 1,547 of the total of 2,873 specimens taken this year in the whole county. At the time of the earlier collections small hatchery ponds were maintained in Urbana by the Illinois Fish Commission, and they were stocked with a variety of fishes from various parts of the state. A collection of fishes made in this hatchery by Professor Frank Snith and Mr. R. W. Mills in November. 1898, included among a miscellany of other fishes 3 specimens of the horned dace between 4 and 7 inches long. It seems very likely that individuals escaping or being released from this hatchery into the West Branch served as seed for the stocking of the entire Salt Fork basin, which formerly did not contain this species. The stiitability of the Salt Fork as an enviromment for horned dace is witnessed by their greater abundance in this stream at present than in other parts of the connty. It would have been most interesting to follow their spread and multiplication in this system, to see how closely their numbers conformed to the logistic curve of population growth; but without such evidence the length of time involved is entirely problematical.

Another case of remarkable increase is that of the silver-mouthed minnow (Ericymba buccata). No minnows of this species were taken in the 8 collections made in May, 1901, in the Sanganon in Champaign County, and only one was taken then in Piatt County; but during last year silver-mouthed minnows have been found in 26 of the 29 collections from that strean, which has thus furnished 1,347 of the 3,519 specimens taken from all the streams of the cotunty.

Evidence indicating the recent appearance of the sleepshead in the upper Sangamon has already been presented.

These cases indicate clearly that certain fishes can fare well in places other than their original habitats. With morlern transportation facilities and fishes being carted hundreds of miles alive, both for stocking pur- 
poses and for bait. it scems certain that within a comparatively short period evidence concerning the original distribution of fishes, as well as racial distinctions, will be olliterated.

There is evidence that the small-mouth black bass is more alsundant in the Sangamon now than formerly. None of this species were taken in the 8 collections made in 1901, lut 12 of the 29 cullections made there in 1928 contained the small-mouth. and these 12 collections furnished 35 of the $4 t$ specimens taken this year in the whole county. It also seems to have increased in the Middle Fork in the same period: for none were taken in the 3 carlier channe! collections while 9 were taken? in the 4 recent channcl collections.

There is some cvidence of decreases in the alumdance of several species. The silvery minnow (Hybognathus muchalis) was taken in ? out of the 8 former collections in the Sangamon. hut not at all in the 29 recent collections in the same stream. The spotted sucker (Minvfrma mclanops) was formerly taken in both the Sanganon and the Middle Fork. but not at all in 3928 . It is possible that the increase in smallmouth black hass in these two streams may have had something to do with the disappearance of the alove fishes.

A number of species formerly present in the stretch of the Salt Fork between Lrbana and the Homer Dam are now absent. obviously because they are not tolerant to pollution.

A few other species in other streams of the comnty may have changed their range or abundance, or hoth, since 1901. but the earlier collections were not extensive enough to justify statistical comparisons except in the Salt Fork and the Sanganon.

The above ol:senations on changes in distrihution do not substantiate the view that the fish life of a stream is a highly integrated whole to which nothing can be arkled or subtracted without upsetting the "Jualance."

\section{AsSOCJATION OF SPECIRS}

Most instances of the association of different species of hislues are explained satisfactorily hy similar envirommental preferences. This phase of the cology of lilinois lishes has been treated very completely and critically ly Professm liorhes in "Fresh-water Fishes and Their Ecology," and "On the Lncal Distribution of Certain Illinnis fishes: an Essay in Statistical Ecology." In these papers he has presented coefficients of association of certinin species with certain other specics and with certain envirommental characteristics. Tahles of such coefficients for important fond and game fishes and their assuciates can be put to good use in formulating principles for the efficient management of our waters and in making recommendations for planting important tishes. in waters where they are not alrealy present. In actual practice a holv of water in which planting is to be done would he inspected as to its general features and the more alumdint linds of fishes noted. Desirable kinds of fishes not already present would he selected for successiul planting from those slowing high cocfficients of association, elsewhere. 
with fishes already present and with the general features of the aquatic environment.

An instance of another order of association of species cane to light in the course of the present study, a new order of association that is distinguished by its extrene exactness. It approaches the order of correllation to be expected between males and females of the same species and implies that at some stage in their life history the presence of both species is necessary for the maintenance of a large population of either.

This new kind of asscciation was discovered in the relations of two large minnows: the horny head, Hybopsis kcntuckicnsis; and the sliner, Notropis cornutus. Onc or both of these minnows were taken in 55 of the 132 collections in the county, and all but two of these 55 collections were made in three river systems-the Sangamon, Kaskaskia. and Middle Fork-the two exceptions being in the Salt Fork basin. Votrofis cormutus occurred in 54 of these 55 collections and Hybopsis kentuckicnsis in 46 of thenl. To put it on the basis of number of individuals: 2,618 specimens of Notropis cormutus were taken in all, of Which 2.590 were in the same collections with Hybopsis kcntuckicnsis; and of the 1.221 specinens of Hylonsis kcntuckicusis, 1.217 were taken in collections with Notropis cormutus. The actual number of each of these species in each of the 55 cnllections in which one or both were taken during 1928 is shown in Table XII.

An inspection of the distribution maps of these two species indicates that they hoth are restricted to certain systems very much as the seventeen other species which have been described earlier in this paper as showing isolation. There are, however. several important points in which these two fishes do not conform with the claracteristics of other species with a restricted distribution. All our other restricted fishes are small (not exceeding $3 \mathrm{I} / 4$ inches in length in this area) and either secientary in habit or restricted to certain limited types of environment. lutt these two are our largest minnows, specimens of both having been taken more than 6 inches in length. Finrthermore, they are both strong swimmers and are not sedentary in any sense of the word. Neither are they restricted to any limited type of environment, both of them having been found in almost every type of stream environment in this area.

It is often mentioned in the literature that Notropis cormutus is a typical snall-strean fish while Hybo,sis kcnithchicus is more characteristically found in large rivers. This rlfference is not indicated by our Champaign County clata. Following is a talulation of the average numhers of these two species per 100 square yards of water area in streams whose sizes are expressed in square niles of clrainage area:

$\begin{array}{llrrrrrrrrrr} & 1 & 2 & 4 & 8 & 16 & 32 & 64 & 128 & 256 & 512 \\ \text { Notropis cormulus } & 10.0 & 25.0 & 8.8 .8 & 64.3 & 132.6 & 141.0 & 31.7 & 35.8 & 10.8 \\ \text { Hybopsis kemuckiensis } & 0 & 4.5 & 2.0 & 46.9 & 74.1 & 33.6 & 11.3 & 17.6 & 9.2\end{array}$

The largest specinen of the shiner was taken in the same collection as the largest chulp. There is, murcove:, a general correspondence between the sizes of these two fishes in all our collections in the county. 
The association of these two species is not olwiously a prerlatorvictim relationship, because studies of their stomach contents slow them both to be omnivores, taking either plant or animal foods oi a wide variety. For many years I have taken these two fishes in almost equal numbers on trout fijes and a variety of other baits on the riffles of 11 ild Cat Creek near Lafayette, Indiana.

The degree of association of these two species in the state at large does not appear so exact as in Champaign County. One or both of them occurred in 203 of the 1.800 collections of fishes reported by Forbes and Richardson. Notropis cormutus occurred in 185. and Hybopsis kuntuckiensis in 139, of those 203 collections. On the lasis of numbers of individuals: 725 of the 85.5 specimens of Hybopsis kenfuckicusis taken in the state were taken in the presence of Notropis cormutus;

Table X1I. Numbers of Hybopsis kcutuckicnsis and Notropis cormutus and total of all fishes in Champaign County collections in which one or both of these species occur. Arranged in order of decreasing stream size within each stream system.

\begin{tabular}{|c|c|c|c|c|c|}
\hline $\begin{array}{c}\text { Hybopsis } \\
\text { kentuckiensis }\end{array}$ & $\begin{array}{l}\text { Notropis } \\
\text { cornutus }\end{array}$ & $\begin{array}{c}\text { Total of } \\
\text { all fishes } \\
\text { in collection }\end{array}$ & $\begin{array}{c}\text { Hybopsis } \\
\text { kentuckiensis }\end{array}$ & $\begin{array}{l}\text { Notropis } \\
\text { cornutus }\end{array}$ & $\begin{array}{l}\text { Total of } \\
\text { all fishes } \\
\text { in collection }\end{array}$ \\
\hline \multicolumn{3}{|c|}{ Sangamon River } & \multicolumn{3}{|c|}{ Kaskaskia River } \\
\hline 6 & 9 & 434 & 4 & 51 & 223 \\
\hline 19 & 8 & 289 & $\ldots$ & 2 & 37 \\
\hline 20 & 28 & 324 & 6 & 100 & 17 \\
\hline 24 & 39 & 332 & 39 & 27 & 128 \\
\hline 17 & 11 & $1+4$ & 14 & 37 & 107 \\
\hline 14 & 22 & 240 & 21 & 66 & 121 \\
\hline 3 & 4 & 236 & 64 & 21 & 134 \\
\hline 15 & 11 & 302 & 111 & 11 & $2 \pi 8$ \\
\hline 36 & 68 & 399 & 8 & 2 & 115 \\
\hline 23 & 4 & 408 & 89 & 33 & 20.3 \\
\hline 33 & 88 & 374 & 42 & 33 & 130 \\
\hline 40 & 193 & 532 & 10 & 76 & 110 \\
\hline 6 & 18 & 83 & 4 & & 14 \\
\hline 21 & 59 & 940 & 4 & 38 & 89 \\
\hline 31 & 150 & 714 & \multirow{2}{*}{\multicolumn{3}{|c|}{ 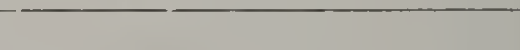 }} \\
\hline 27 & 212 & 506 & \multirow{2}{*}{\multicolumn{3}{|c|}{ Middle Fork River }} \\
\hline 28 & 161 & +42 & & & \\
\hline 25 & 134 & 320 & \multicolumn{3}{|c|}{$13 \begin{array}{lll}\text { Midale Fork kivet } & \\
43 & 15\end{array}$} \\
\hline 51 & 135 & 376 & \\
\hline 55 & 137 & 503 & \multicolumn{3}{|r|}{152} \\
\hline 10 & 50 & 321 & \multirow[t]{2}{*}{7} & 35 & 420 \\
\hline 123 & 41 & 261 & & 2 & 137 \\
\hline & 32 & 41 & 3 & 110 & 305 \\
\hline 68 & 41 & 321 & \multirow{2}{*}{ 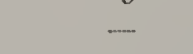 } & 4 & 182 \\
\hline 2 & 37 & 152 & & 3 & 546 \\
\hline 3 & 1.3 & 35 & \multicolumn{2}{|l|}{$\ldots$} & 174 \\
\hline 31 & 73 & 649 & \multicolumn{3}{|c|}{ Salt Fork River } \\
\hline$\cdots \cdot-\cdot$ & $\begin{array}{r}14 \\
1\end{array}$ & $\begin{array}{r}160 \\
43\end{array}$ & sal & Fork Kiver & 37 \\
\hline 1 & 11 & 19 & - & 2 & 324 \\
\hline
\end{tabular}


conversely. 2,184 of the 2,666 specimens of Notropis cormutus were talien with Hybopsis kentuckicnsis. The lower incidence of these two species and the comparative smallness of the earlier collections would tend to lower the probability that specimens of both would he included in any given collection. However, the state-wide data does contain some evidence that one of these species, particularly Notropis cornutus, can occur in larger streams independent of the other.

The general distribution of Notropis cormutus is given by Jordan and Evermann ${ }^{13}$ as,- "Entire region east of the Focky Mountains excepting the South Atlantic States and Texas: almost everywhere the most abundant fish in small streams. Its variations are great, some of them appearing like distinct species." The general distrilution of $\mathrm{Hy}$ bofsis kcntuckicnsis is given as.-"Penrsylvania to Wyoming and Alabama, on both sides of the Alleghenies; everywhere abundant in the larger streams, seldom ascending small brooks; western specimens usually have the teeth in two rows. Variable."

Reports on the fishes of many other areas within the range of these species clearly indicate a correspondence of the detailed distribution of the chub with the shiner.

The explanation of why these two species show isolation in certain stream systems seems to be embodied in the nature of their association. It may be that, while they are necessary to each other's existence at least to attain aluundance, the necessity of their association extends over only a part of their life history, so that they can move into other areas independently of each other. Whether or not they shall occupy the new area, may then depend on the small probability that they should both get there at the same time.

\section{SumMary}

Champaign County, which is nearly level upland plain, embraces the neighboring headwaters of six stream systems which diverge in various directions, sending their waters into the tributaries of the IValuash on the east and the Mississippi on the west.

Quantitative collections containing 28,905 fishes were made in 1928 from 132 localities on these streams, and with these were combined for sturly the product of 40 collections from this same area, made in the course of a general survey of the fishes of the State in the period 1882-1901. The identity of the specimens from all these collections has been determined, and the rlata of their distribution and abundance in the different seasons and in the several habitats of each stream have been organized to show factors affecting distribution. These two series of collections, together with a few miscellaneous collections and reports from Champaign County, include representatives of 74 species.

13. Jordan, David Starr, and Evermann, 13arton Warren: "The Wishes of North and diddle Ant+rica." Pulletin 47. Smithsonian Institution, $\mathcal{L}$. S. Sitiona! Mristum. 1896. 
From the data of 1928 it appeared that the streams of the county contained an average of three fishes per square yard of water. equivalent to 15,000 fishes per acre, with a total weight per acre of about 150 pounds.

Data of temperatures and rainfall are given for 1928, when the collections were made, and for the 26 years during which accurate observations have been recorded.

Dredging of the streams for farm drainage is common. and its effect on the fishes are temporarily serious: but erosion and the growth of water plants and of stream-side shrubs and trees presently reproduce original conditions, so that the general effect of dredging is not important.

The coarse aquatic plants of the waters of the connty are listed with statements as to the situations in which they occur.

Nine principal classes of habitats in Champaign County streams are recognized, and the species of fishes most characteristic of eacli are listed.

The number of fishes per unit area varies from seven per square yard in extreme headwaters down to two per square yard in the larger streans, but this decrease in number of fishes downstream is more than counterbalanced by an increase in the average size of the indivilual fishes.

In comparing the range of stream sizes which different species inhabit, it was found most satisfactory to throw the data on drainage areas into size classes which increase as a geometrical progression, each class being macle twice the preceding class; for the numbers of fishes per unit area and the numbers of species per collection, when plotted against stream sizes on this scale. give curves that approximate straight linesa good empirical reason for assuming that this is a correct method of comparison.

Some species which reach their greatest abundance at certain points in a stream also reach their greatest abundlance in other streams at points with the same draingge area, withont reference to distance from source or mouth.

Some species are sharply limited to a certain stream size. while others are more generally distrihuted but fluctuate alout a certain streanu size as a mode.

Although the young and adults of most species reach their greatest abundance in streams of the same size, the youg of certain species of suckers regularly occur in smaller streams than do adnits of the same species.

Fishes of the extrene hearwaters are the harcliest. most tolerant of pollution, and most nearly onmivorous.

Correlation hetween unusual fertility of soil and abundance. rate of growth, and adult size of fishes is illustrated by an extraordinarily: productive tract drained by Spon River which yielded twice as nany fishes to a given area and four to five times as many pounds of fish as the average for the county. 
The effects of pollution are illustrated by an extreme scarcity of fishes - as for example, downstream from Champaign and Urbana, notwithstanding the operation there of a modern sewage disposal plant ahove which there were thirty times as many fishes per unit area and four tines as many kinds as lelow. (See footnote 10, page 54.)

There are distinguished three types of morphological adaptation of fishes to the size of streams and velocity of their flow.

Notwithstanding the close neighlorhood of the headwaters of the different stream systems and the similarity of their habitats and of their drainage basins, the local distribution of their species is so restricted that 17 species are wanting in from one to five of the six stream systems of the county; but examples are given of the alsility of species thus isolated to survive and multiply in other waters if they gain access to thenr.

Attention is called to the indispensable importance of a knowleclge of the natural limitations of the distribution and survival of economic species in different habitats, without which wasteful efforts will he made to introduce desirable species where they cannot thrive.

Two species, Hybopsis kentuckicnsis and Notropis comutus, exhibited an extraordinary and unexplained association, being found together in 99 per cent of the collections in which either one of them occurred.

\section{DISTRIBUTION MAPS}

On the following pages distribution maps are shown for all species which were represented by ten or more specimens in the collections of 1928. Circles indicate places where collections were made in 1928, and triangles where collections were made in the period 1882-1901. The occurrence of each species is indicated by the use of these symbols in solid black. (For index, see p. 90.) 

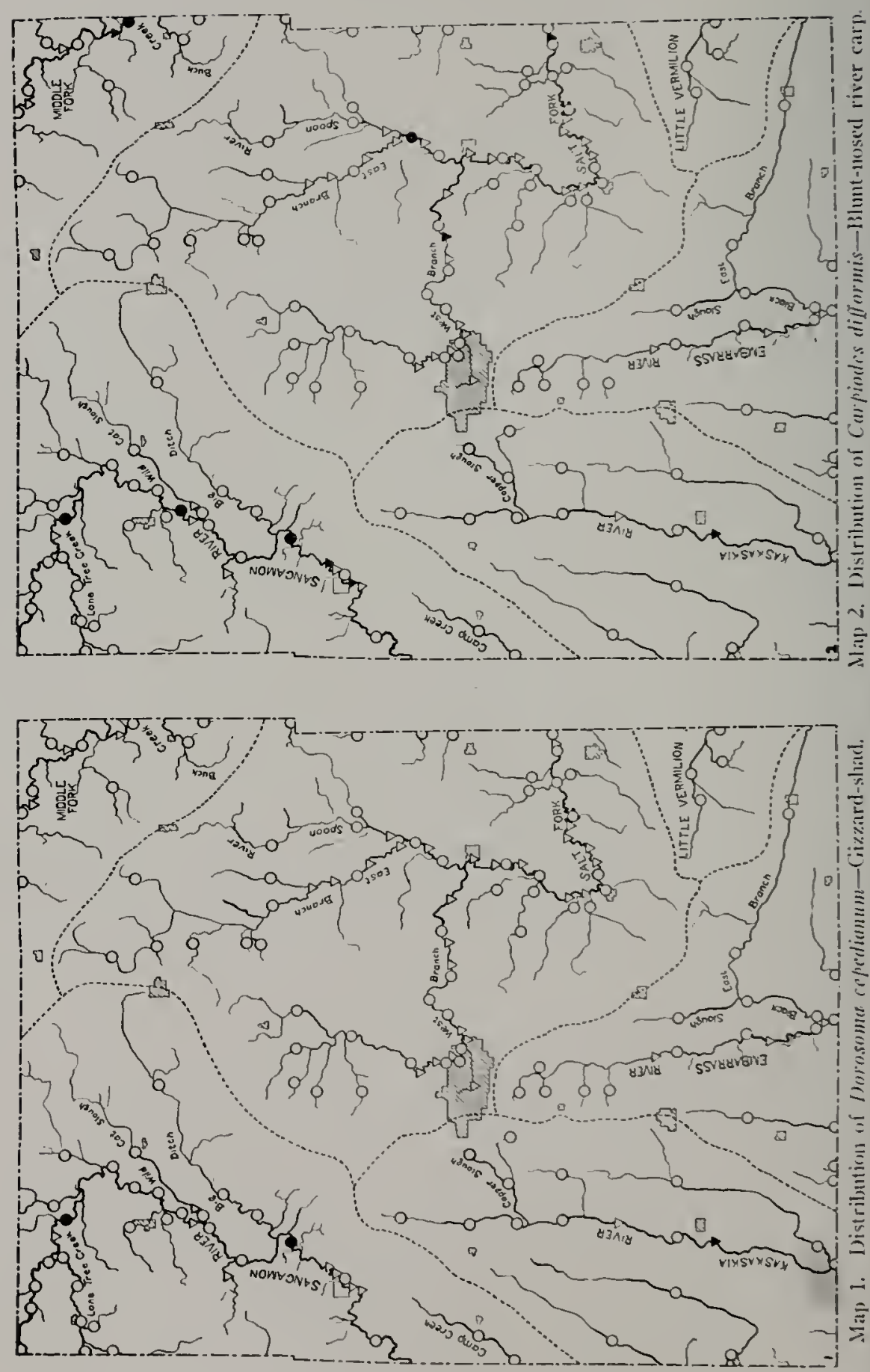
Fishes of Champaign County
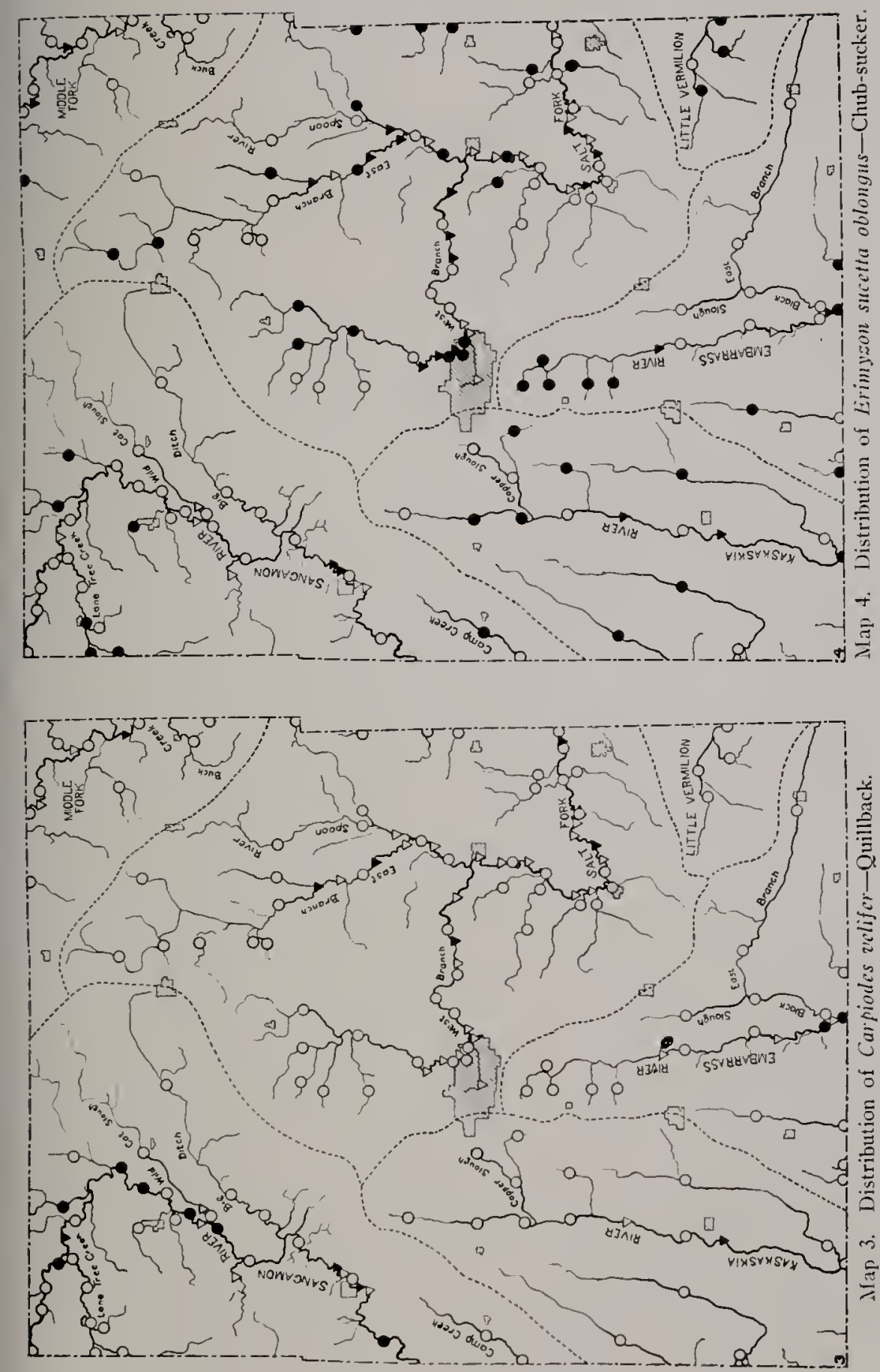

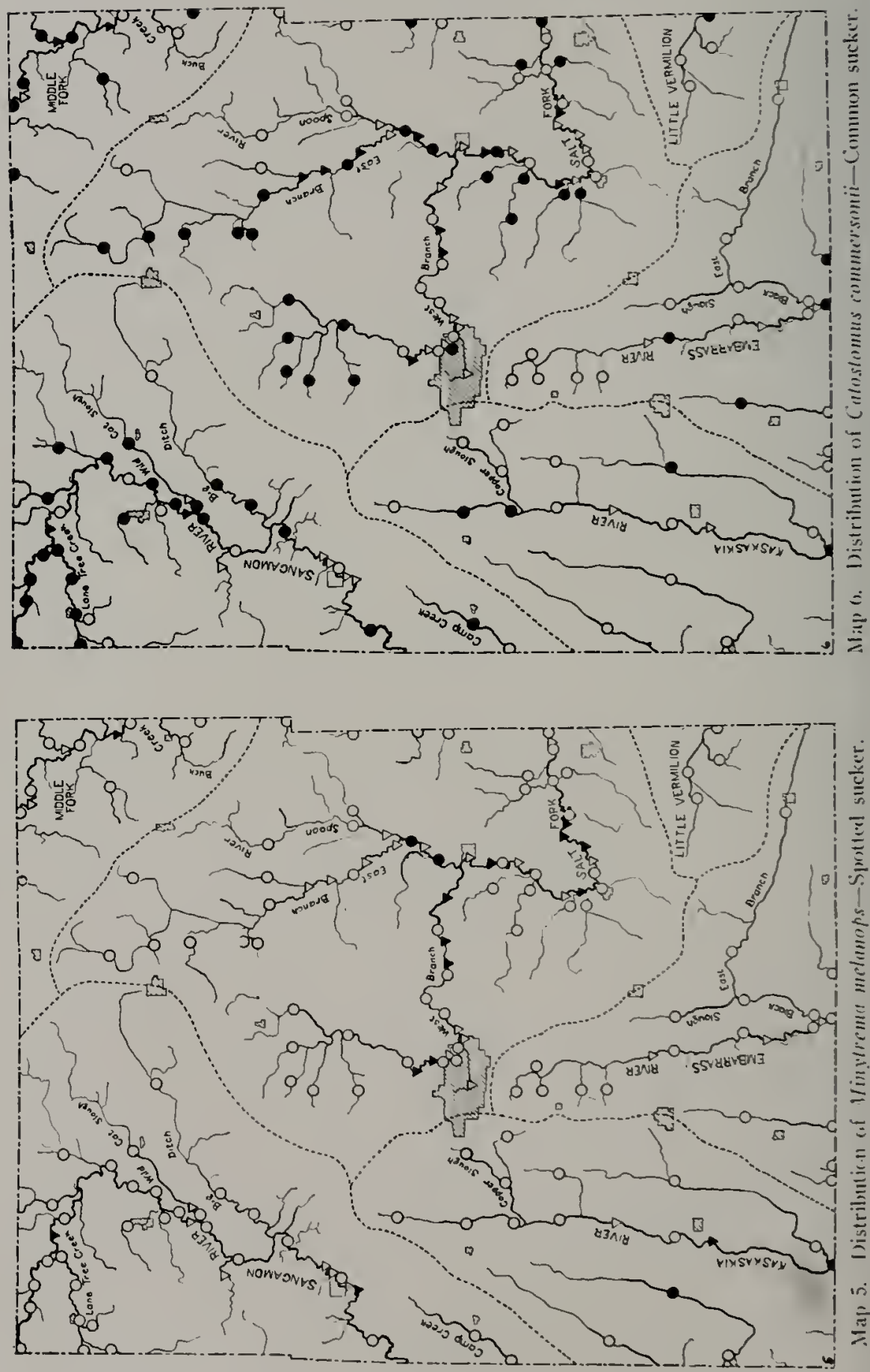

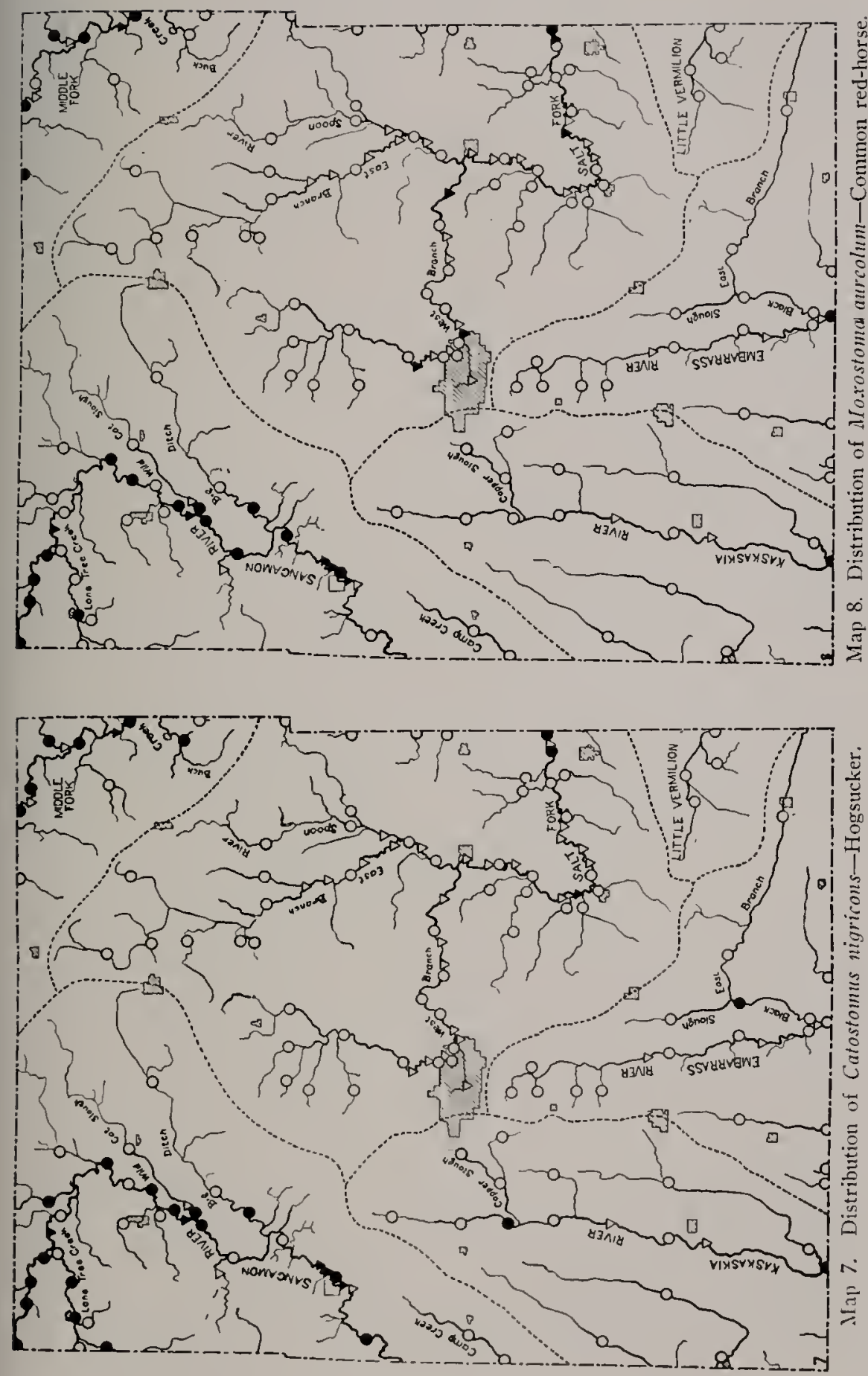

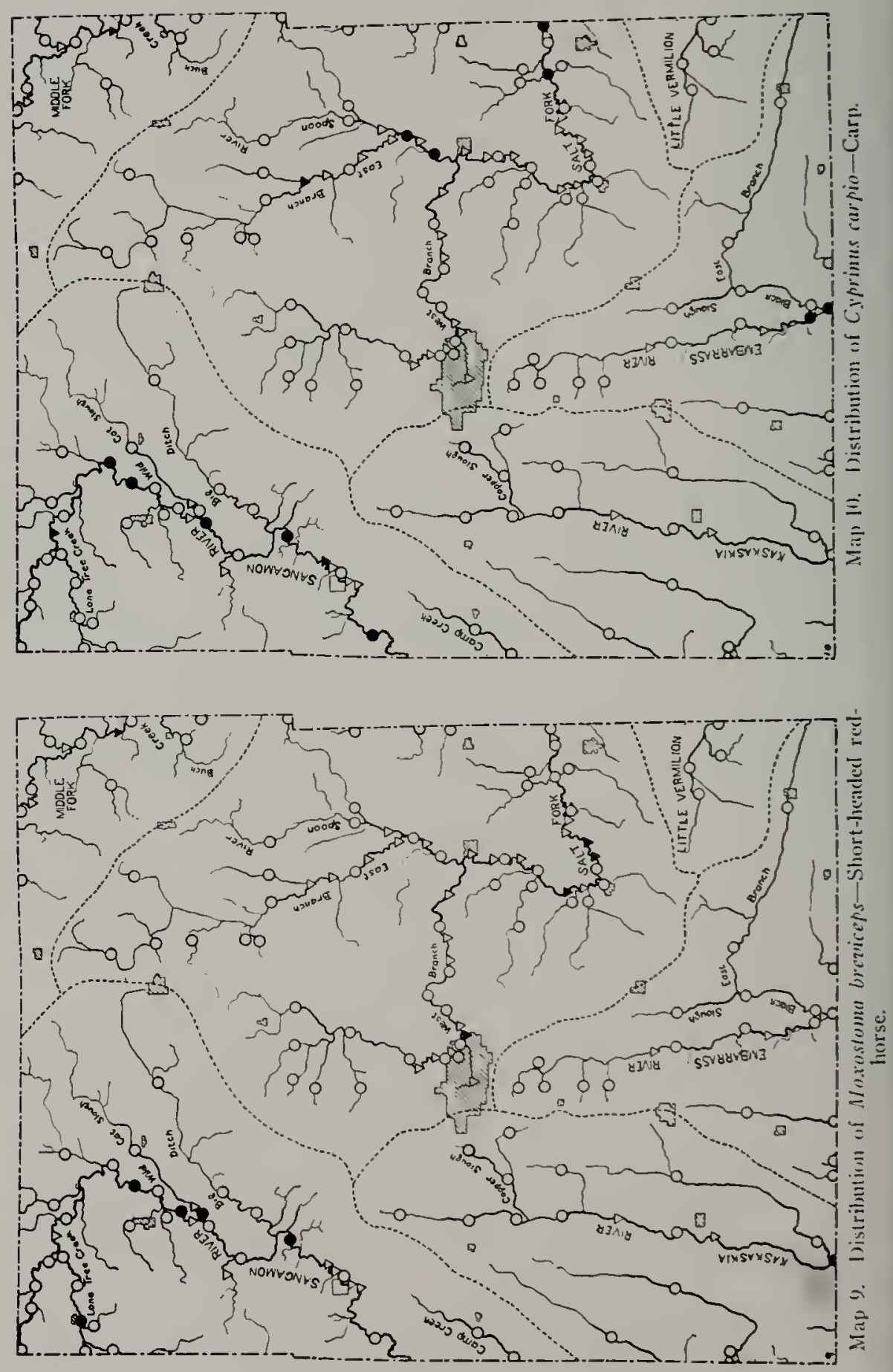

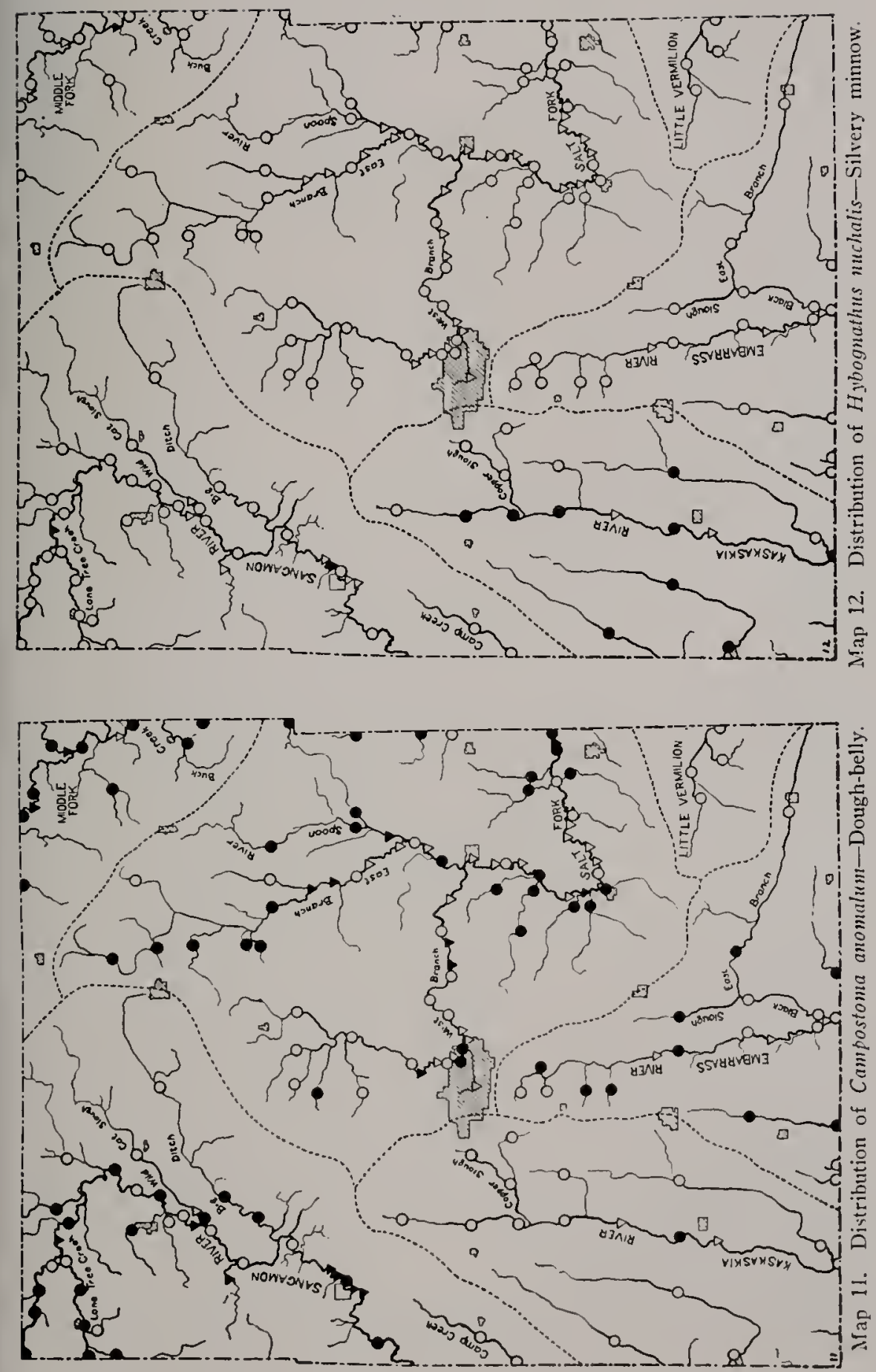

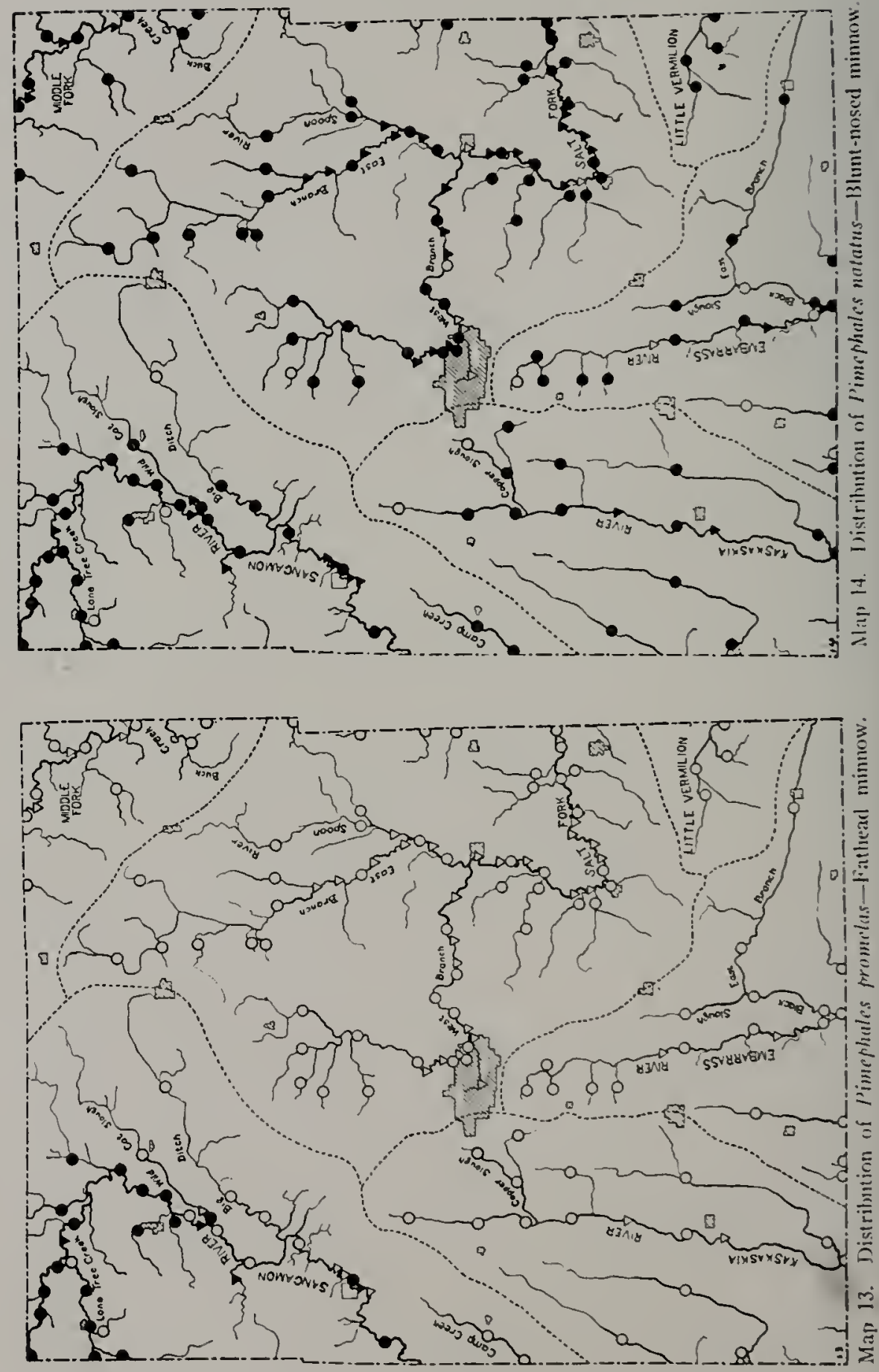

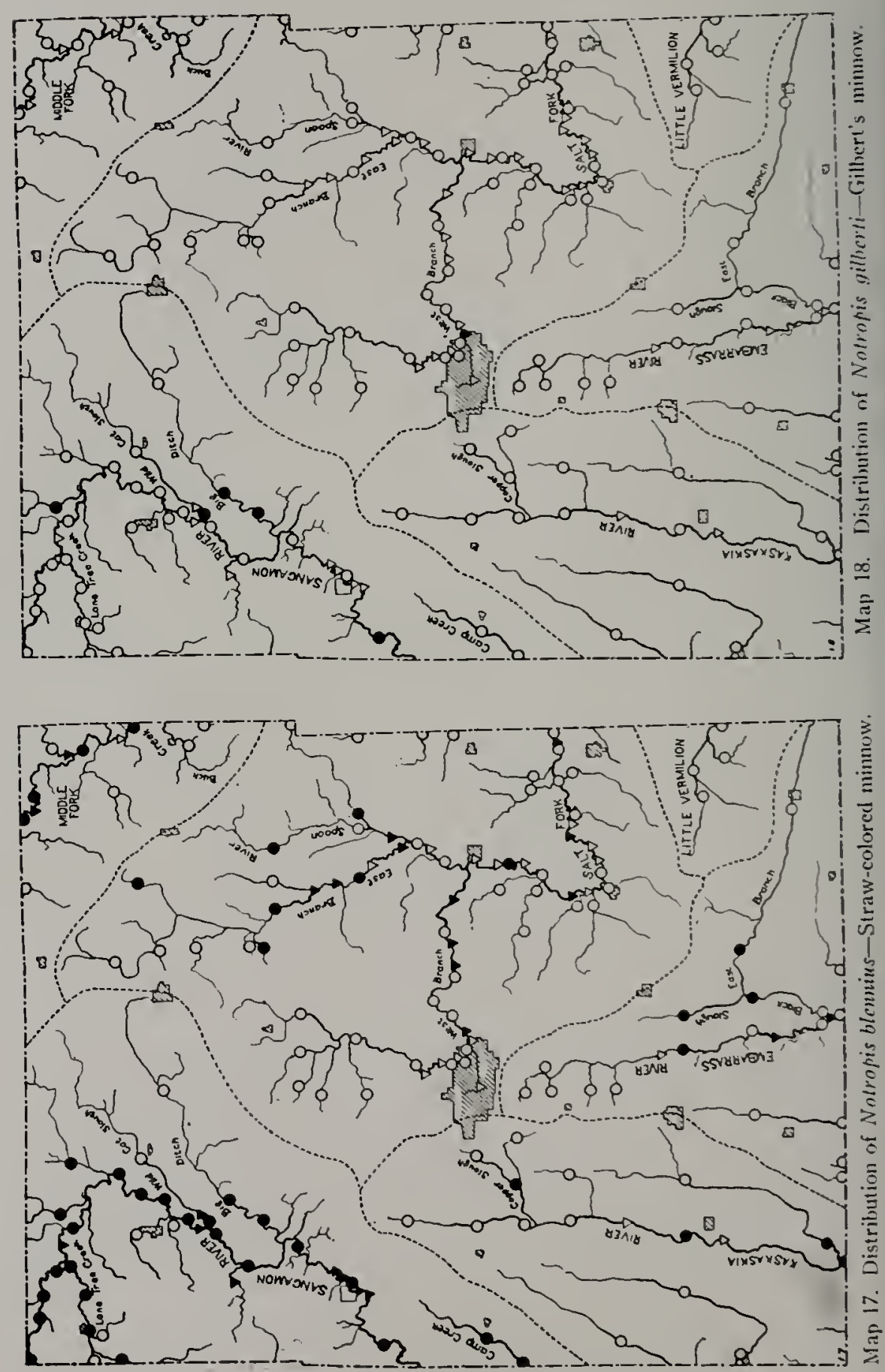

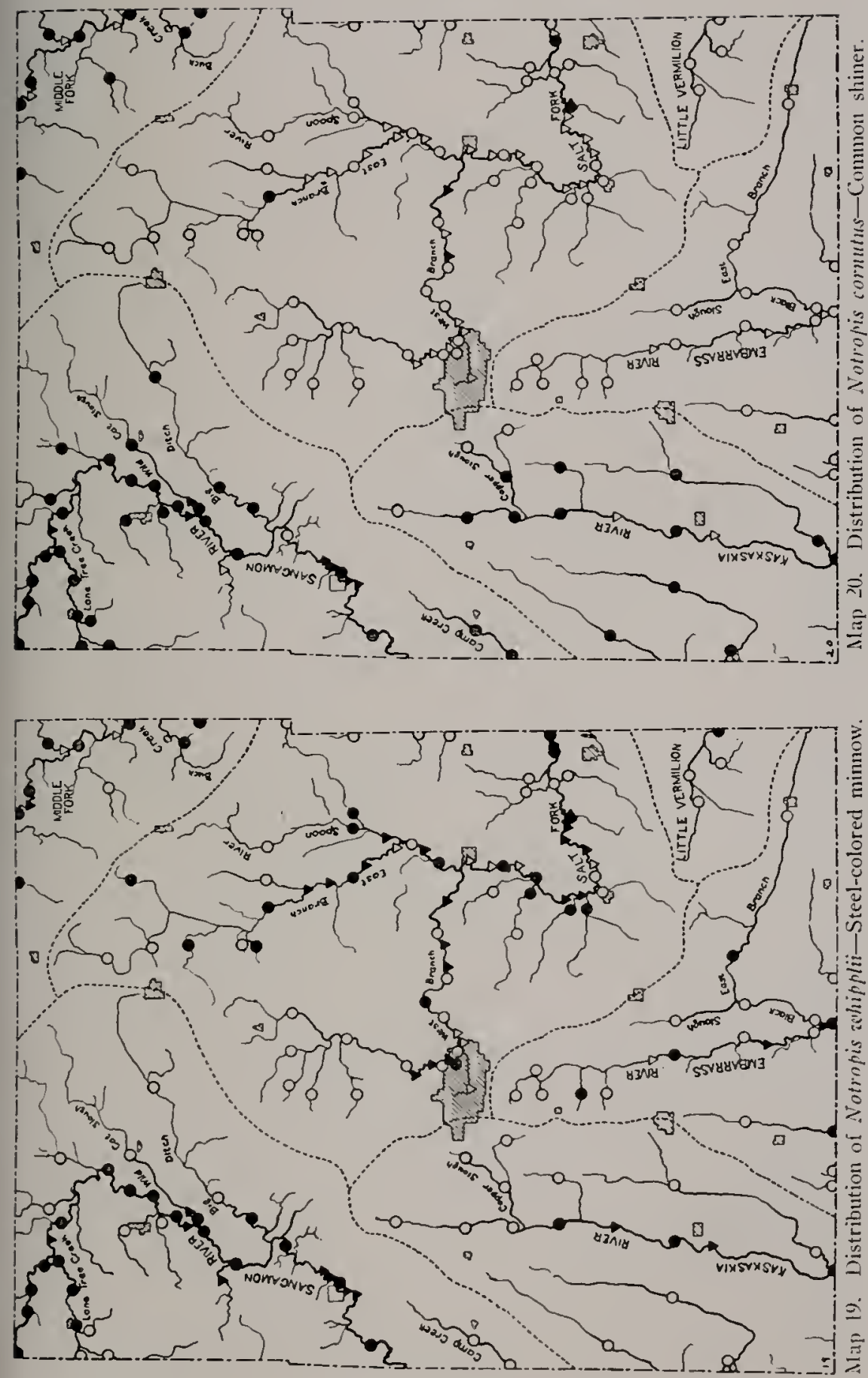

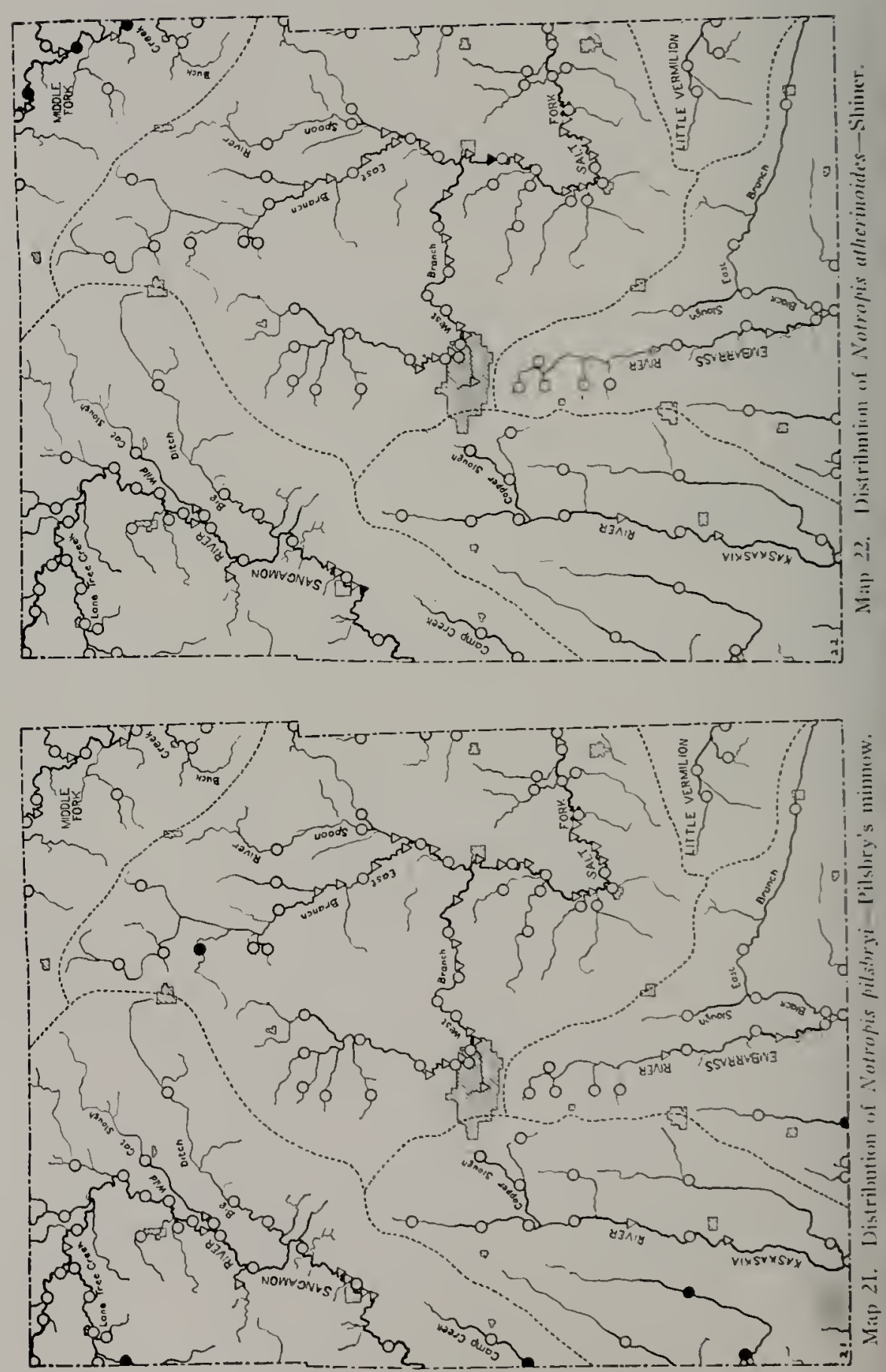

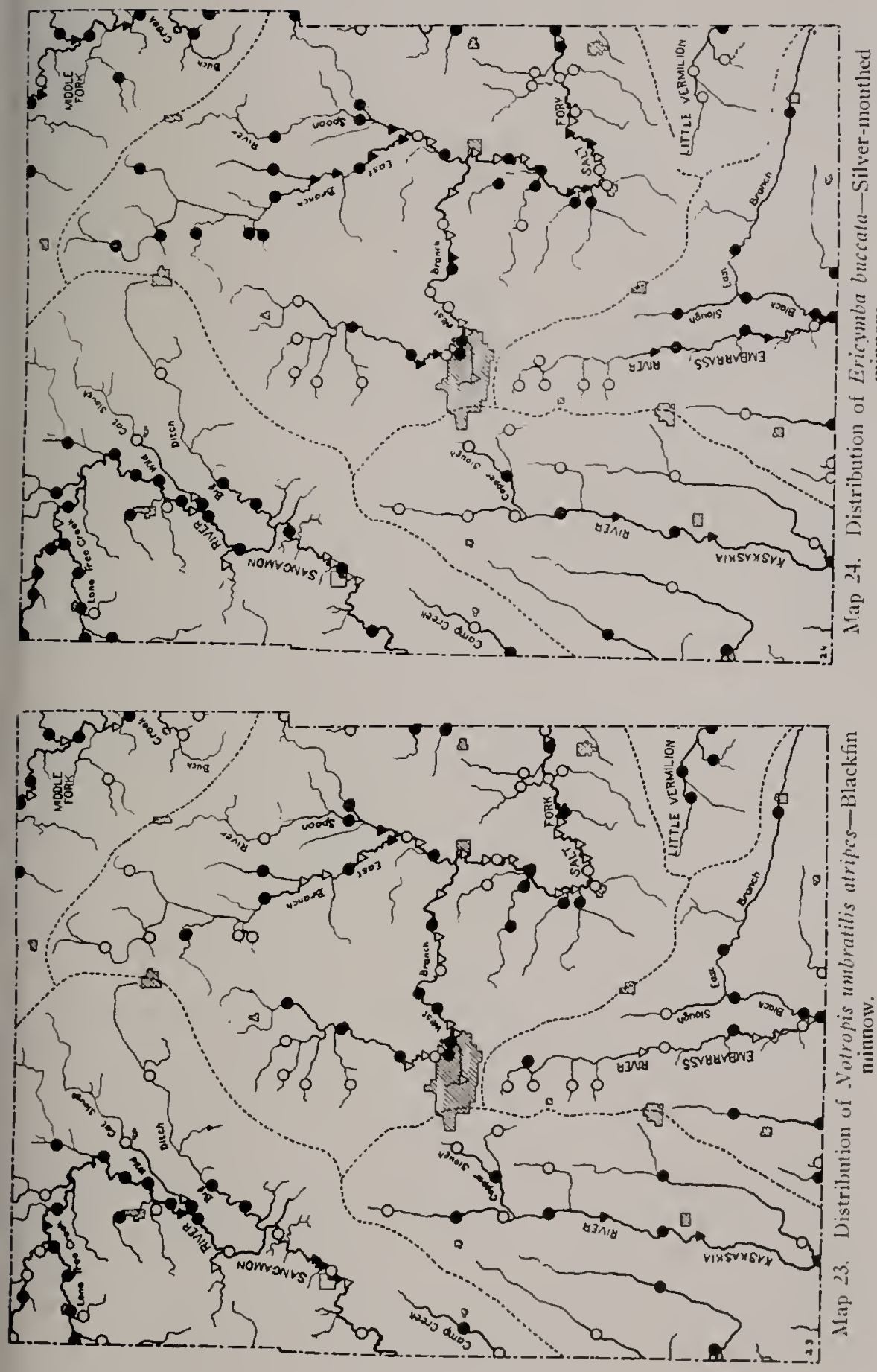

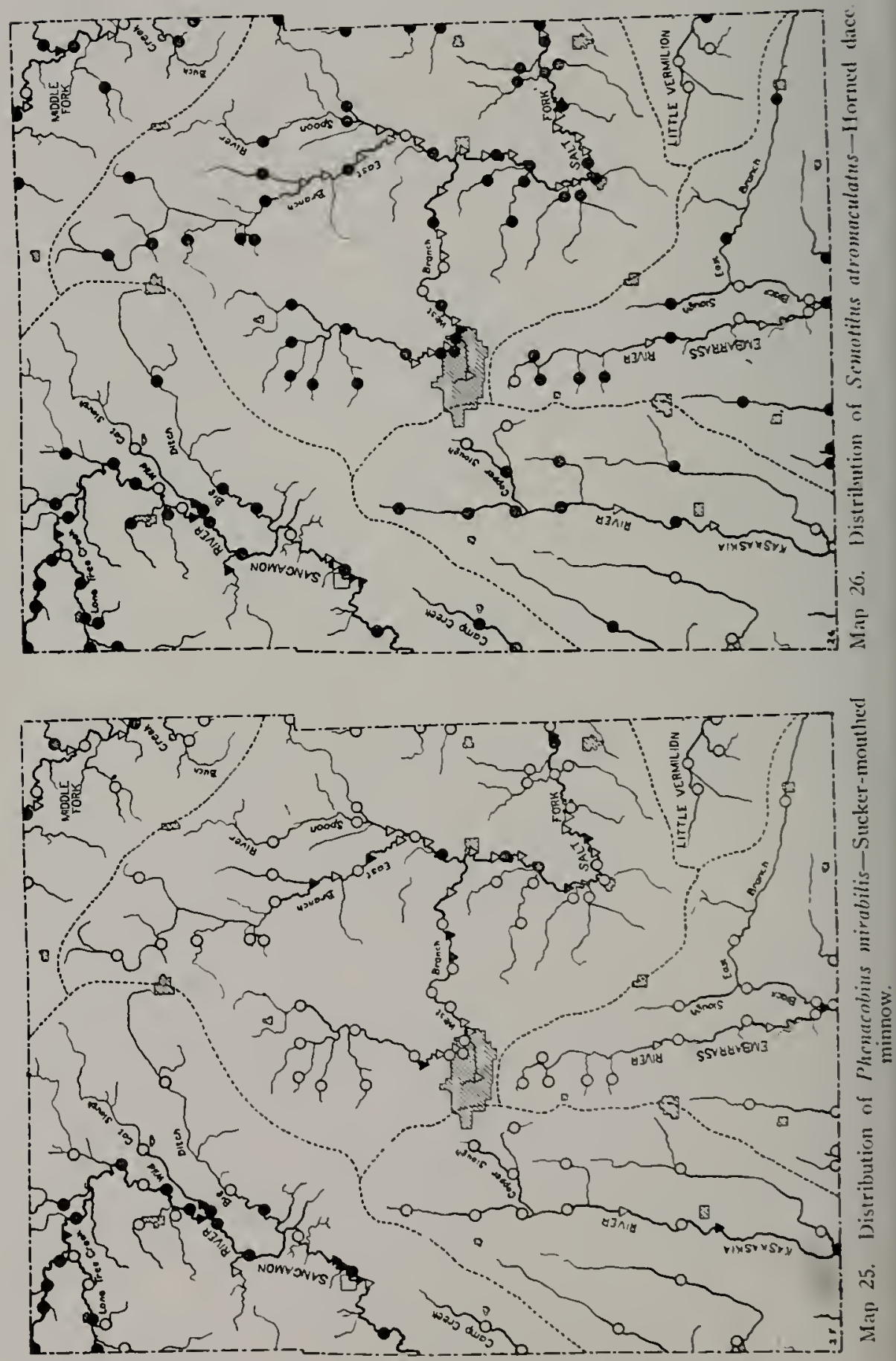
Fishes of Champaign County
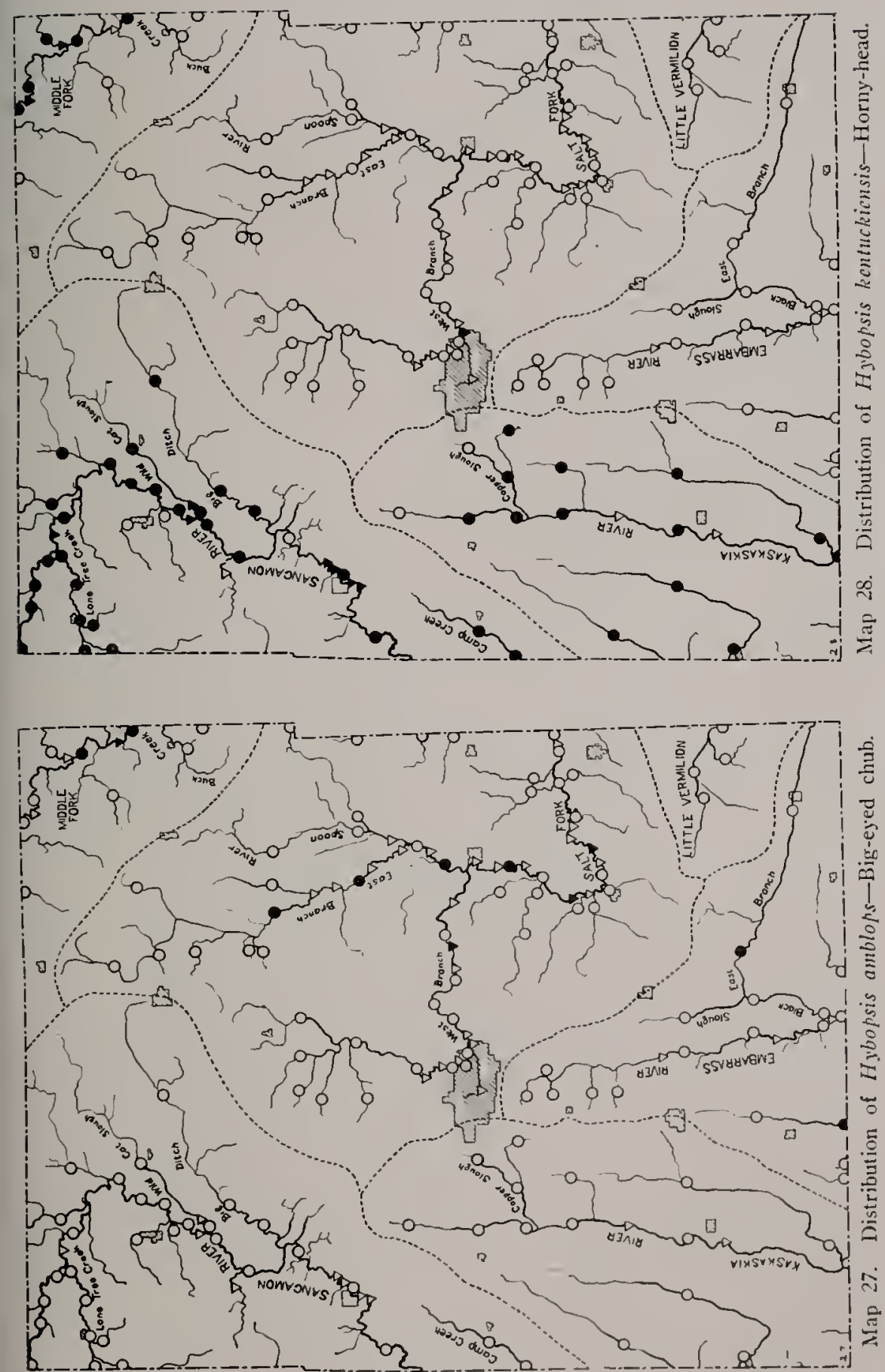

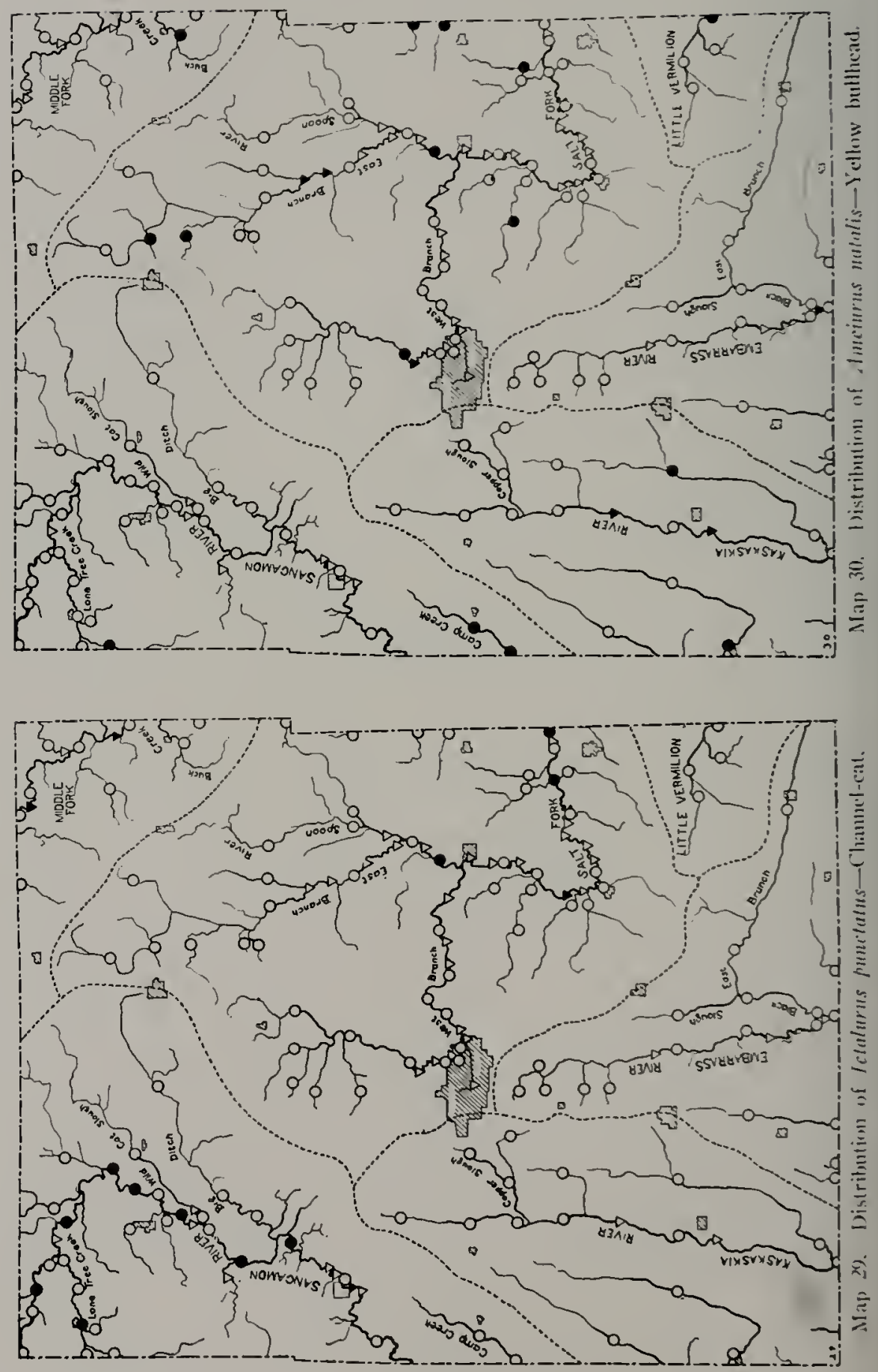
Fishes of Champaign County
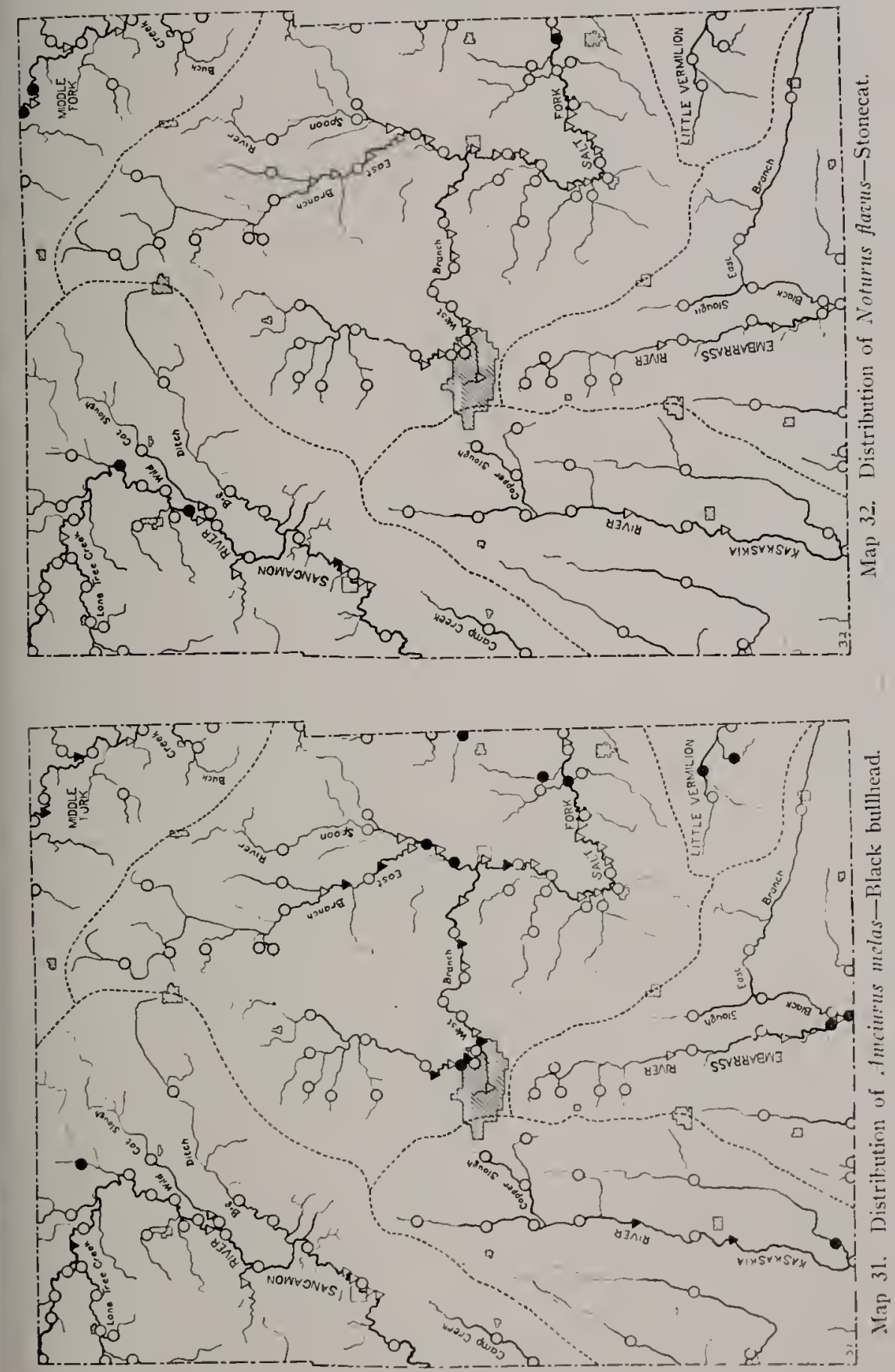

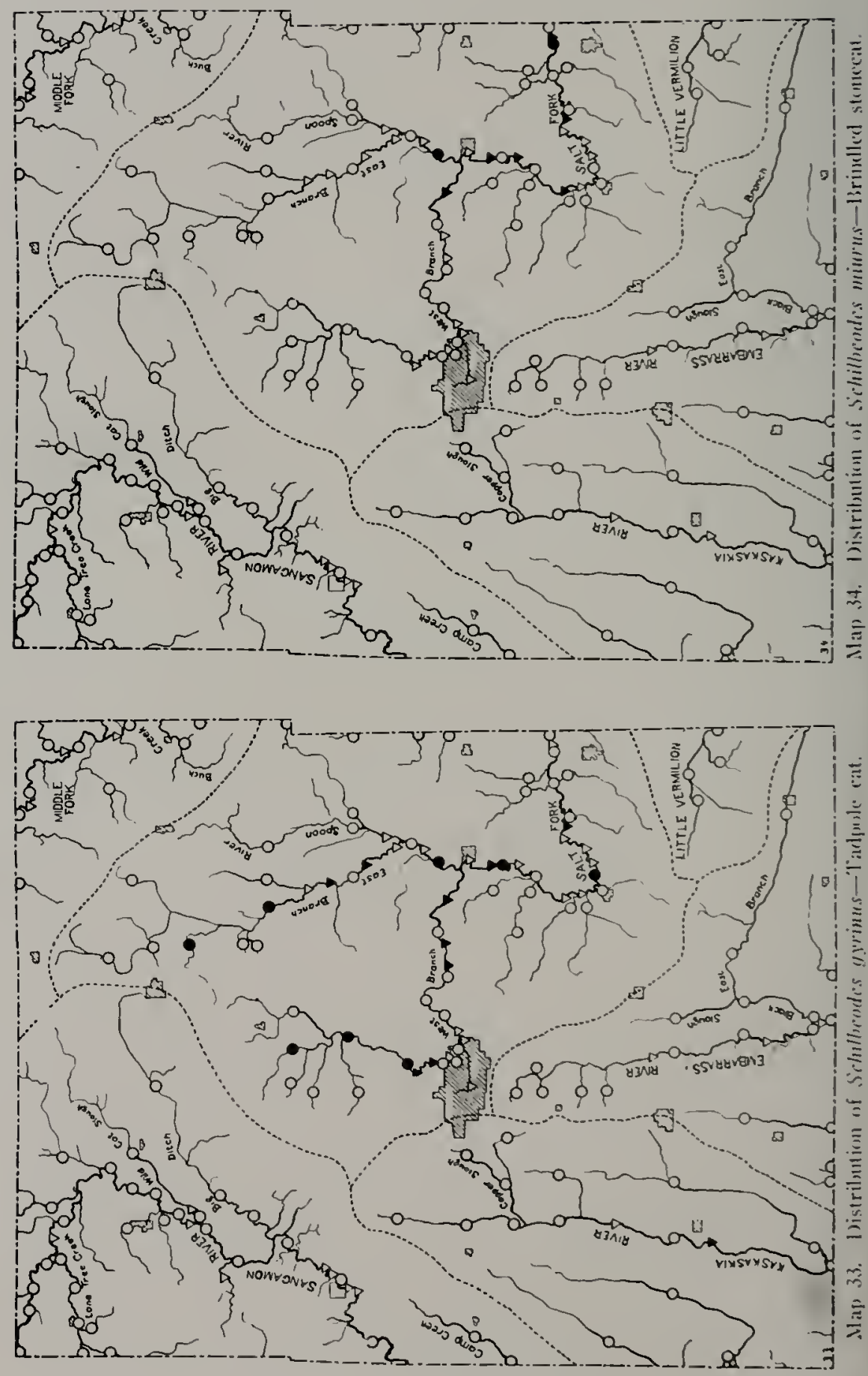

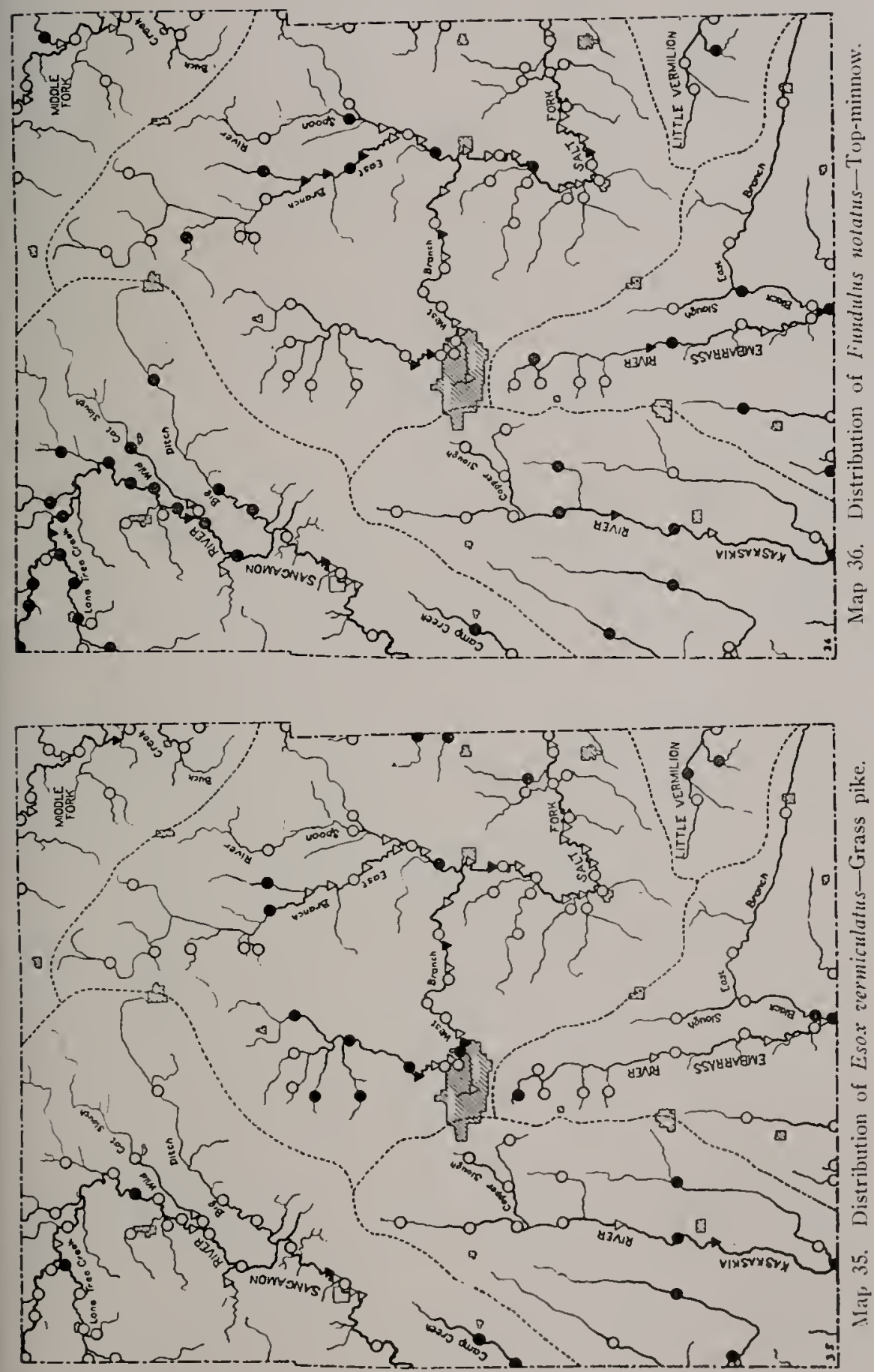

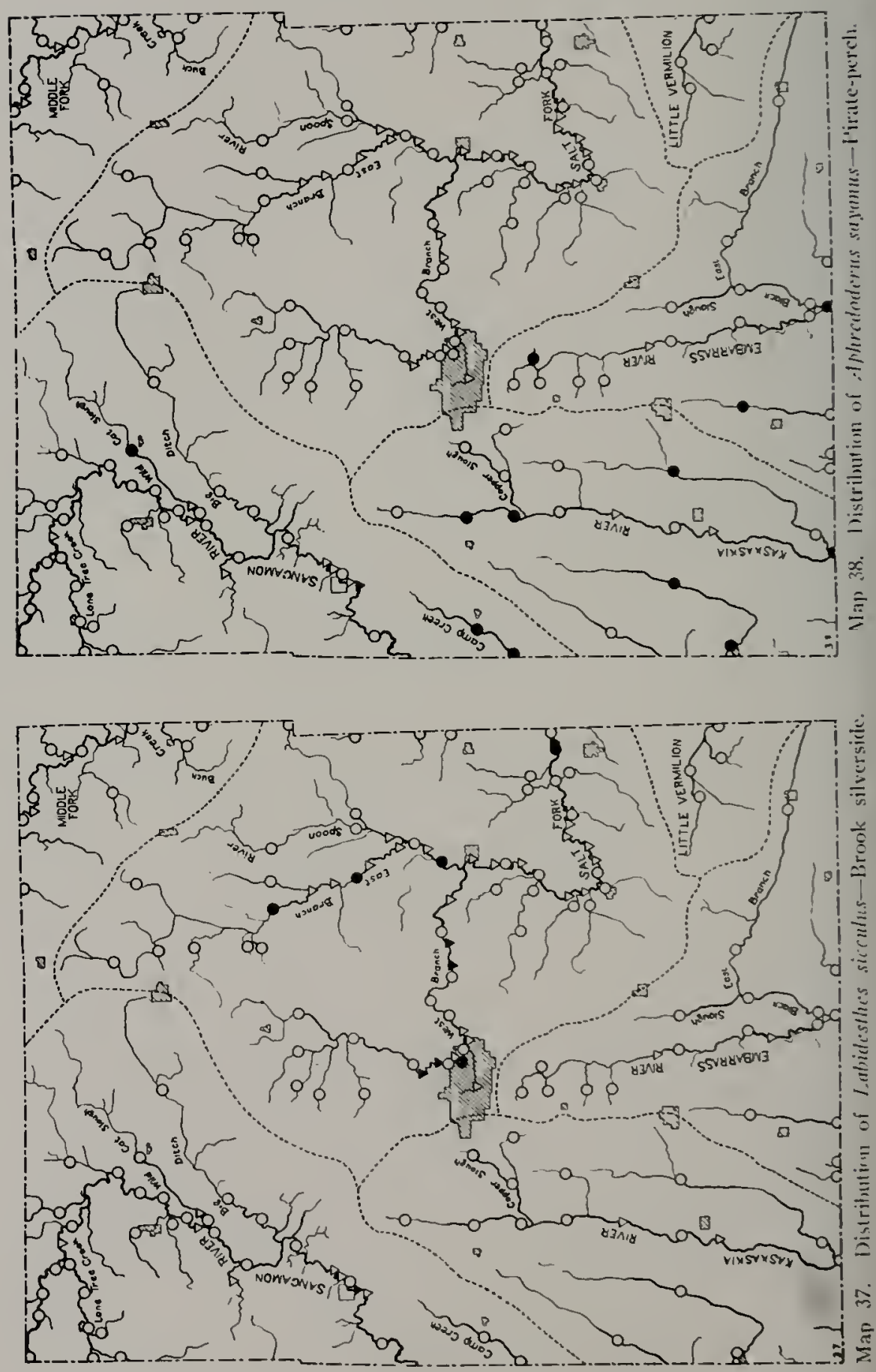

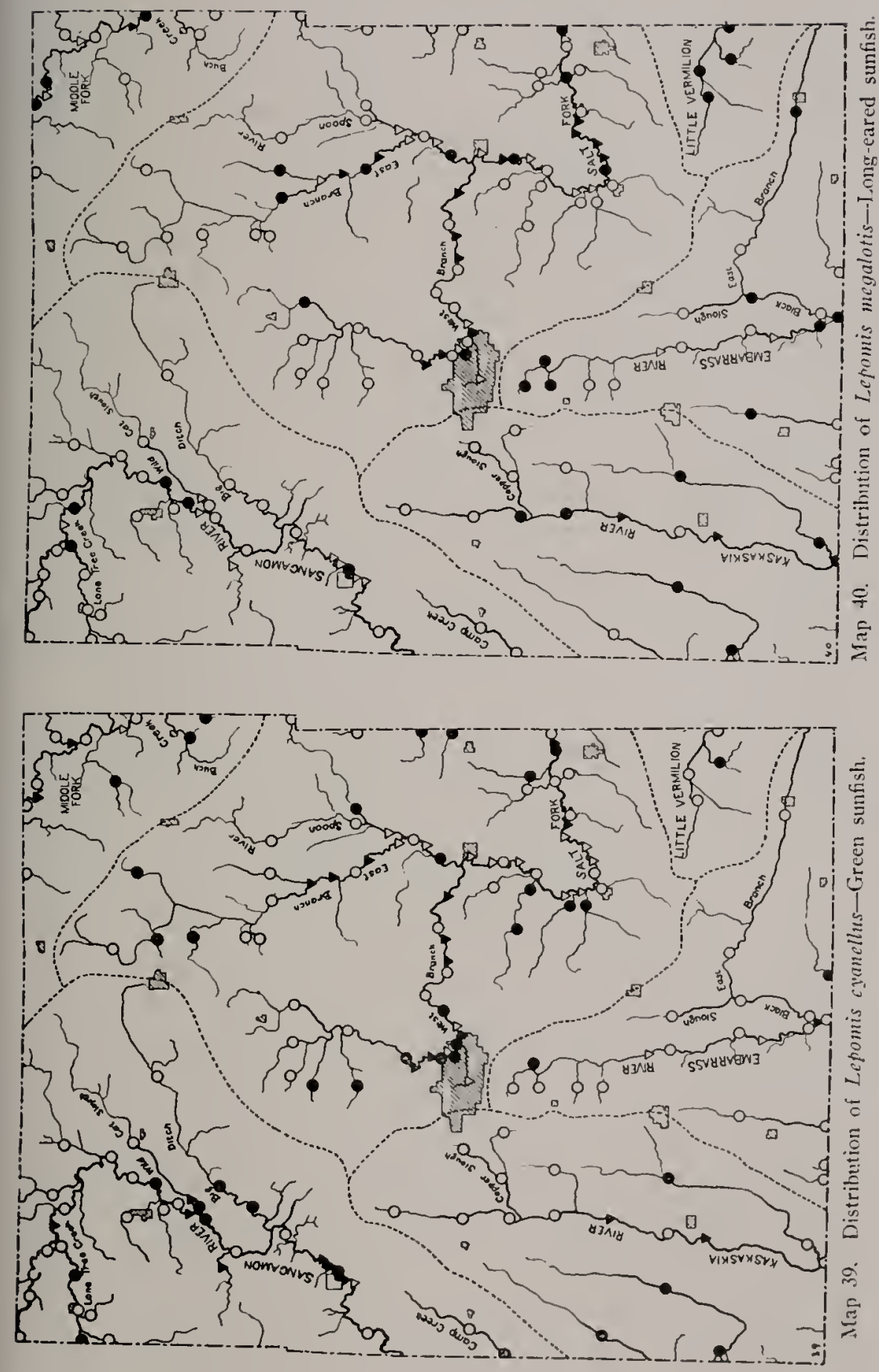

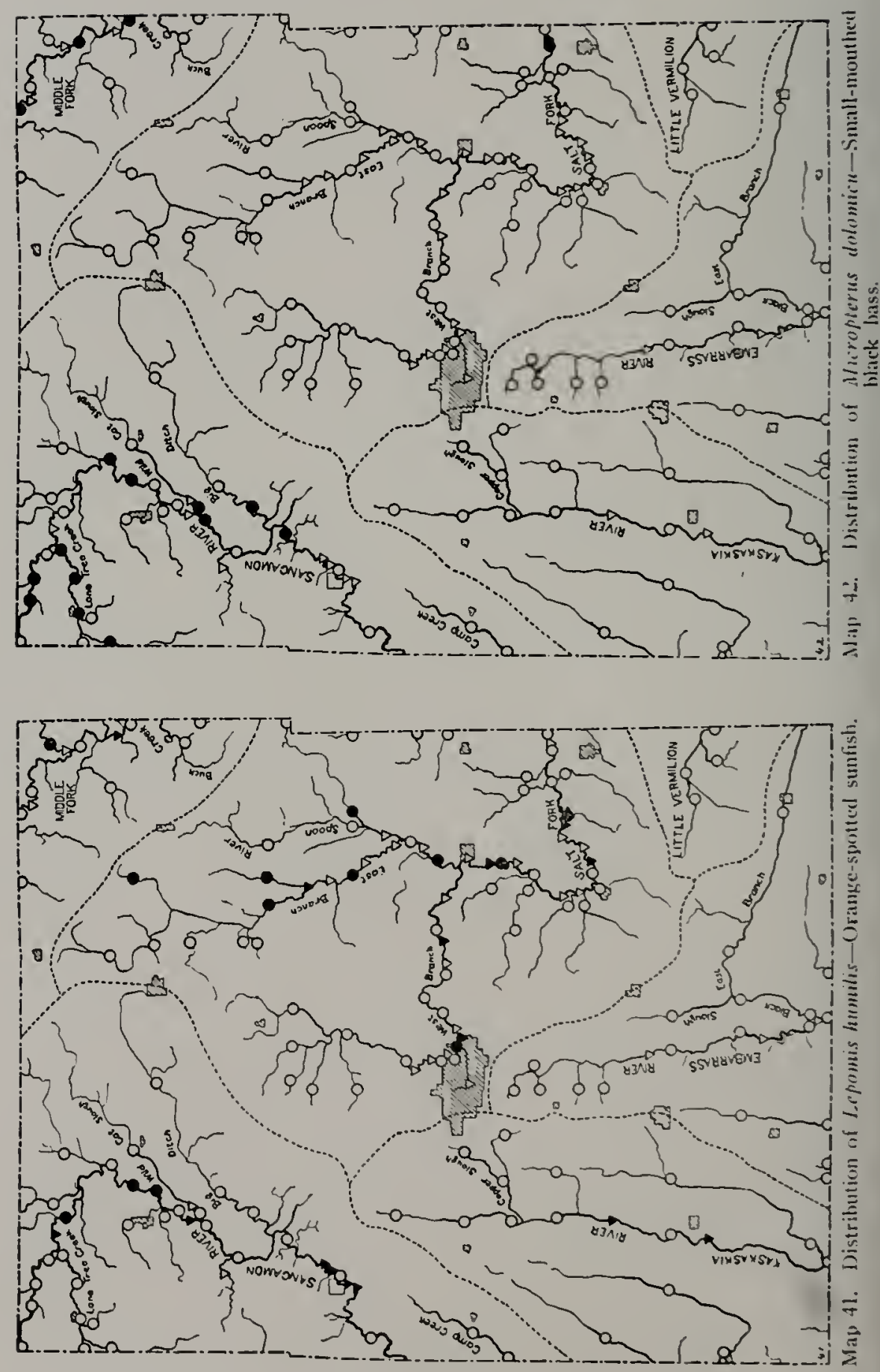

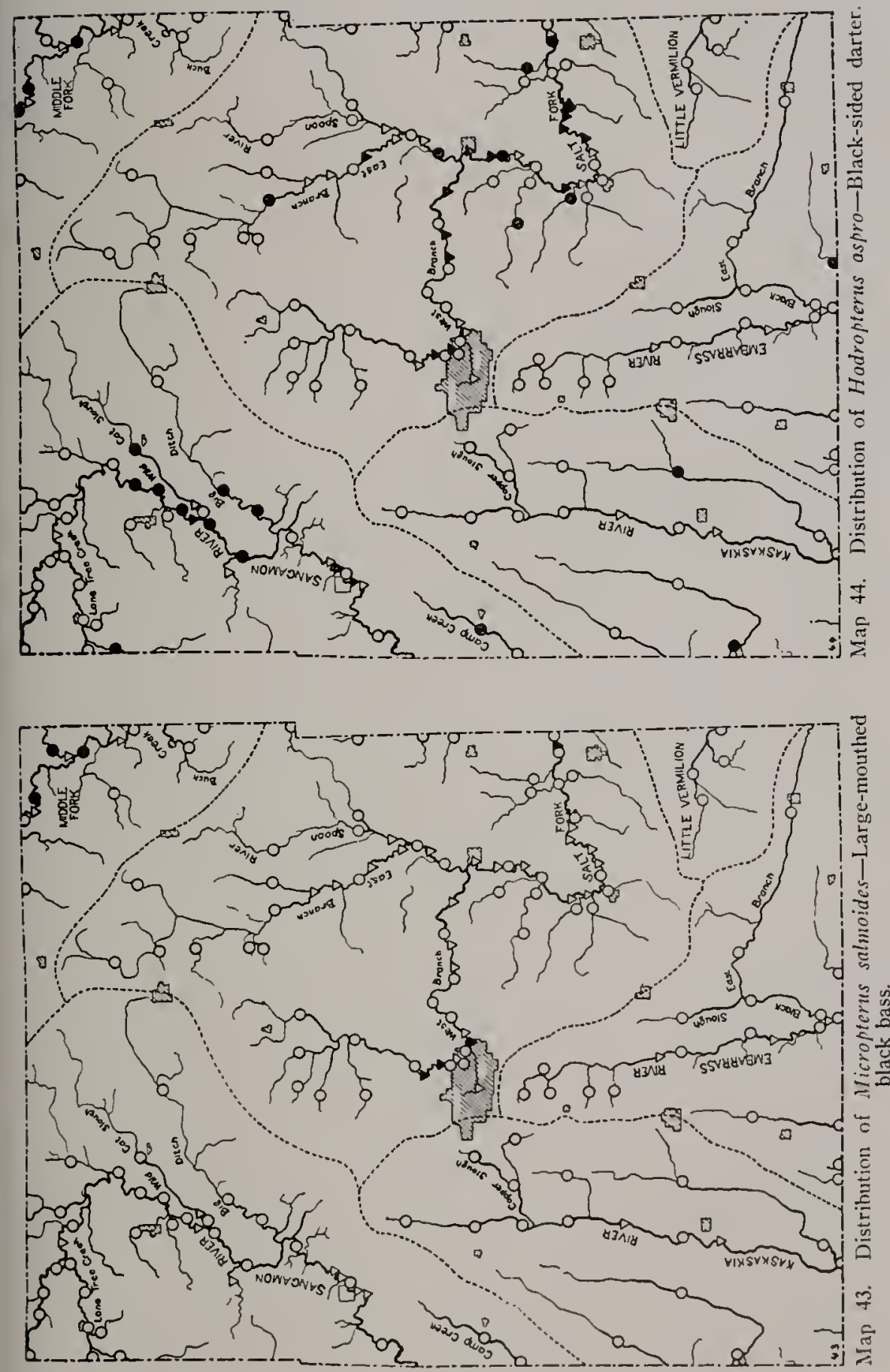

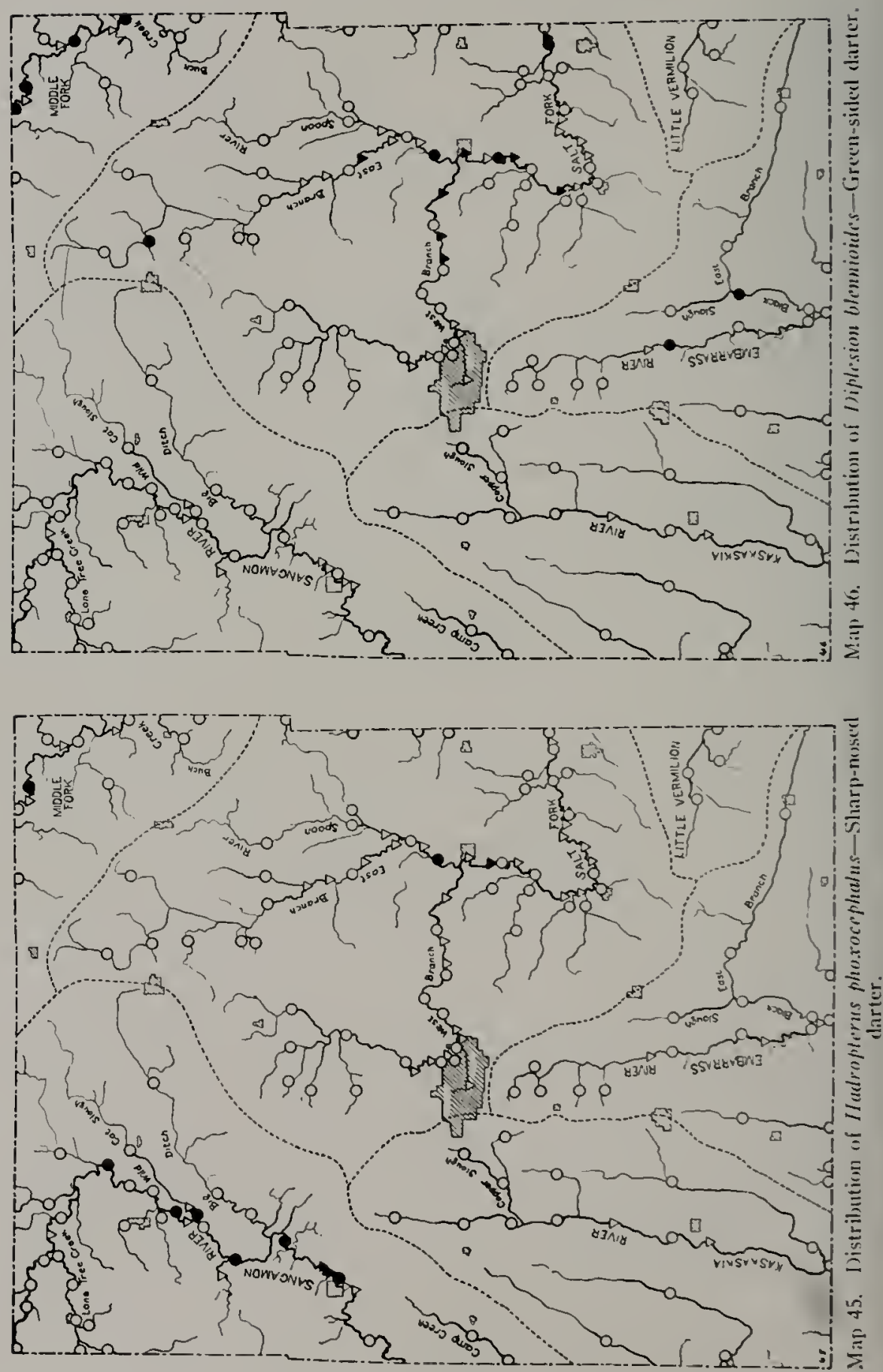
Fishes of Champaign County
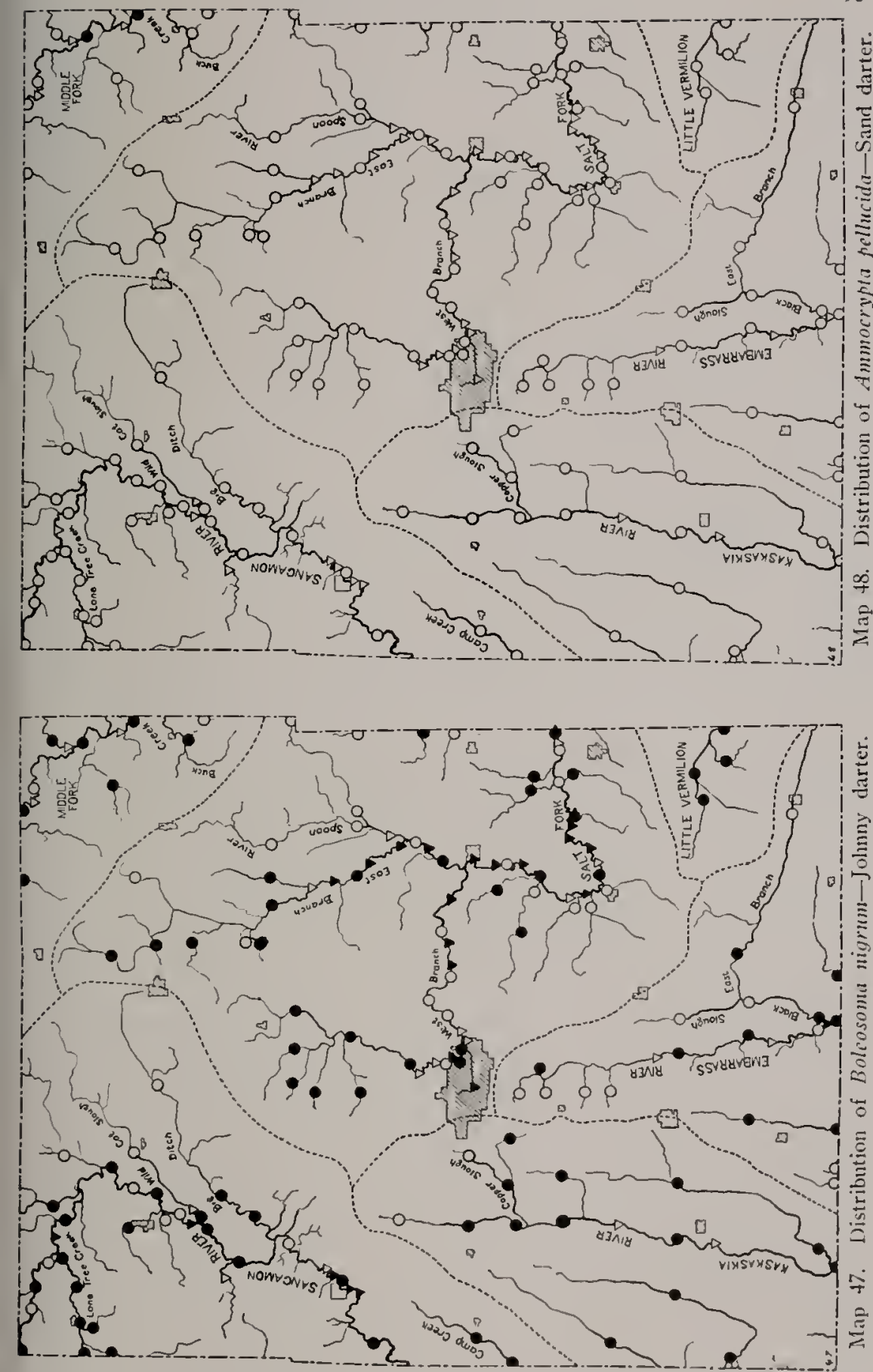

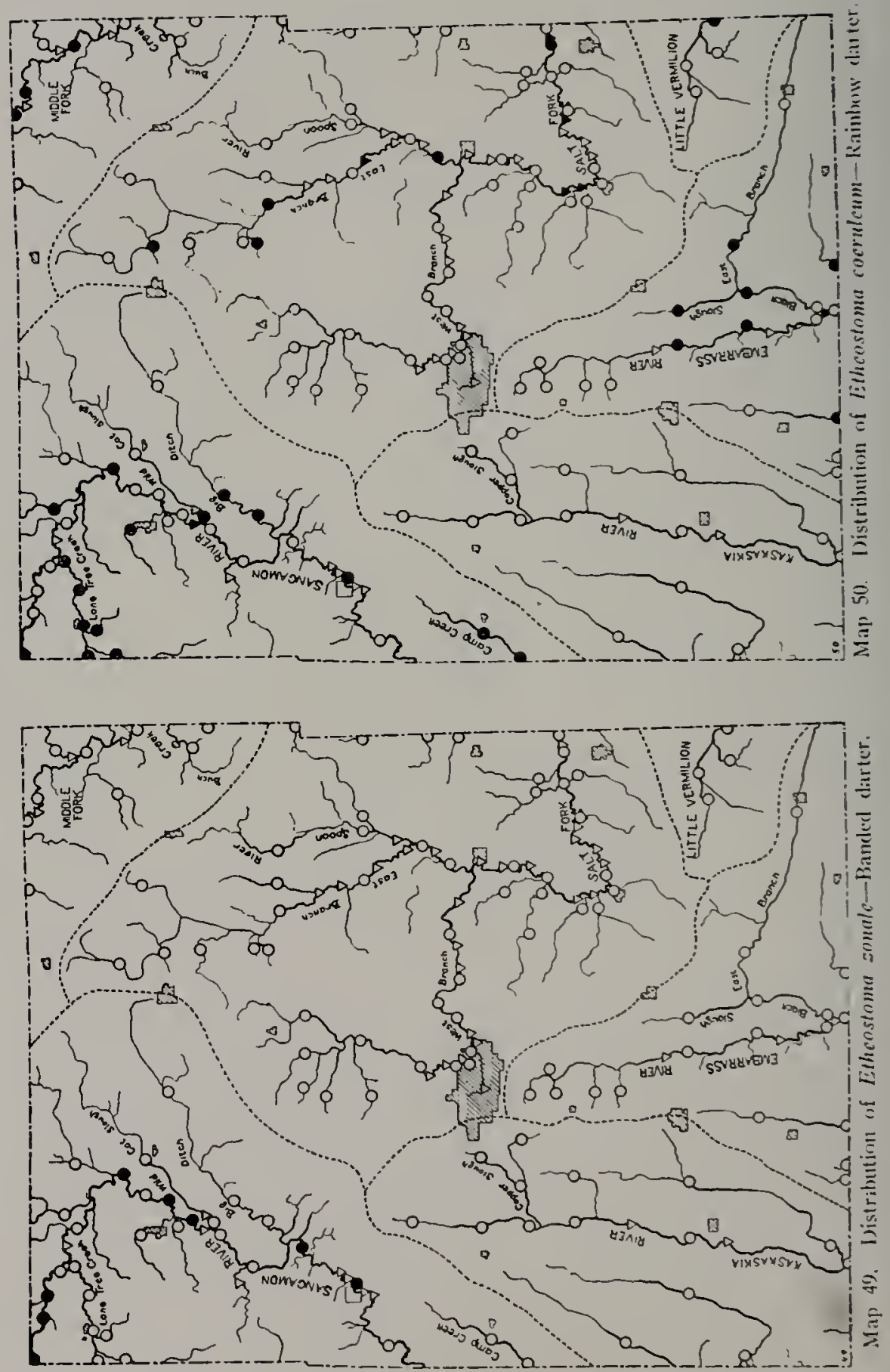

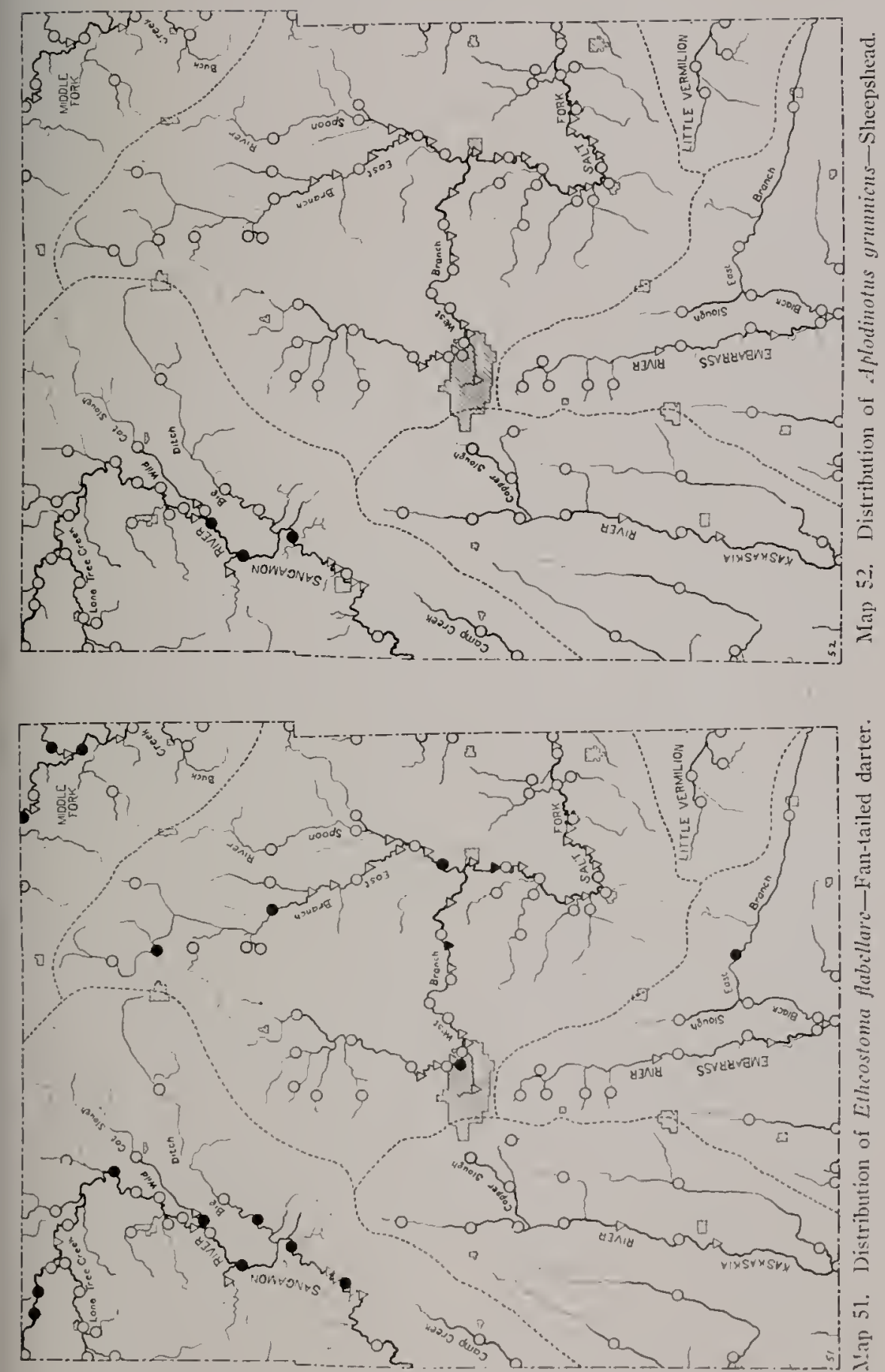
Revised Names of Champaigx Colnty Fisines

Names used by Forbes and Richardson in "The Fishes of Illinois." 1909.
Names userl by Jordan in "Manual of the Vertebrate Animals of the Northeastern Lnited States." 13th ed.. 1929.

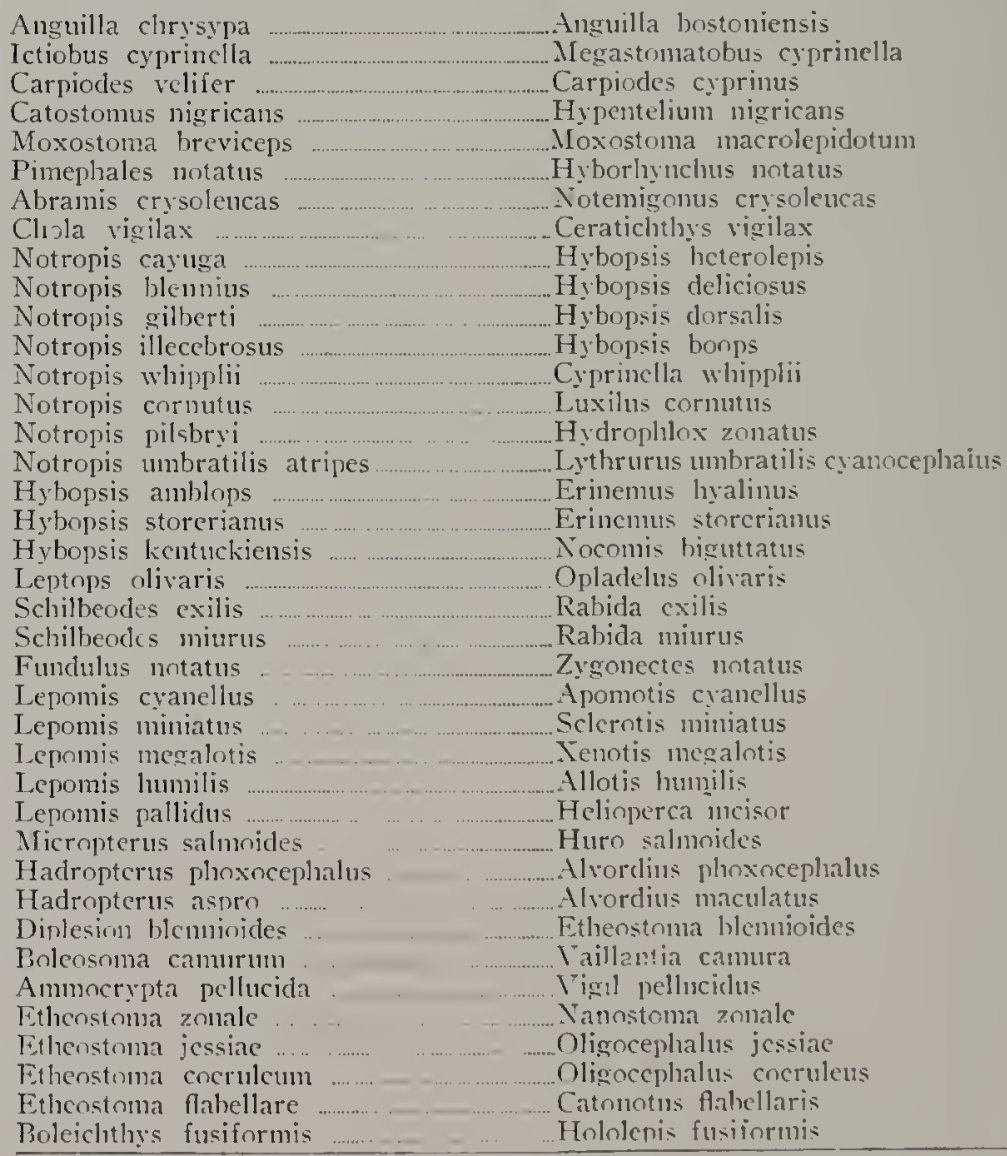




\section{INDEY TO NAMES OF SPECIES}

Abramis crusolcucas, $34,35,36,44,47$ 53,$50 ;$ Map 15, p. 79.

Ambloplices rupestris, $29,44$.

Amciurl's melas, 26, 35, 39, $44,47,53$; Nap 31, p. 87.

Amcimris natalis, 26, 44; Map 30, p. 86. Ammocrypta pellucida, 33, 45, 44; Map 48 , р. 95.

Ancuilla chrysypa, 17, 19, 45.

lhimedoderus sayanis, $28,36,45,64$ : Map 38, p. 90.

Aplodinotus grmmicns, 33, 39, 45; Nap 52. p. 97.

Banded darter, see Ethcostoma zonale.

Big-eyed club, see Hybopsis amblops.

Big-eyed minnow, see Volropis illecebrosils.

Big-mouth buffalo, see lctiobus cyprinc!lla.

Black bullhead, see Ameinurs melas.

Black crappie, see Pomoris sparoides.

Blackfin minnow, see Notropis umbratilis atripes.

Black-head minnow, sce Pincpinules promelas.

Black-sided darter. see Hudropterns aspro.

Black sucker, sae Culoslomus commersonii.

Bluegili, see Lepamis pallidus.

Plunt-nosed minnow, see Pincphales nolatus.

Elunt-nosed river carp. see Carpiodes difiarmis.

Bolcichtly's fusiformis, 33, 45 .

Bolcosoma camurum, 33, 45, 48.

Bolcosonta niarum, 32, 36, 37, 45, 53. 56; Мap 47. p. 95.

Bream, see Abrumis crysalcucas.

Brindled stonecat, see Schilbedes nimrus.

Bronk silverside, sec Labidesthes siccullis.

Bullinead minnow, see Cliola aigilax.

Campostoma anomalum, 23, 34, 35, 37 . $40,43,47,53,56$ : Мap 11, p. 77.

Carp. see Cyprinus curpio.

Carpiodes difformis, 21, 39, 43; Map 2. p. 72 .

Carpiodes ielifer, 21, 37, 38, 43, 60 : Мар 3, р. 73.

Catostomus commersnnii, 21, 35, 36, 37. $38,39,40,43,47,49,53,56$ : Мар 6. 1. 74 .

Cutostomus niqricans, 21, 37, 38, 43 : Map 7. p. 75.

Cayuga mimuow, sec Vofropis capusa alrocuudalis.

Chacuobryilus gulosus, 29, 44
Channel-cat, see Ictalurns punclalus.

Chub-sucker, see Erimyzon sucolla ablongus.

Cliola aryilux, 23, 44, 64: Map 16, 1). 7\%.

Common recl-horse, see Morotomu ailrolum.

Common shiner, see Votropis cormutus.

Common sucker, see Calostomus commersonii.

Creek Chut, see Scmotilus atromaculatus.

Cyprimus iarpio, 23, 39, t4; Map 10, p. 70 .

Diplesion blcmioides, 32, 37, 45, 64, 05: Map th, p. 94.

Dorosoma cepedianum, 19, 39, 45: Map 1, p. 72 .

Dough-belly, see Campostoma anomalim.

Eel, see Anyuilla chrysypa.

Ericjmba bucala, 25, 35, 37, 40,44, 47 48, 53. 56, 62. 65; Map 24, p. 83.

Erimyzon succtta oblongus, 21, 34, 36, $43,47,53,56$ : Map 4, 0. 73.

Eso.t icrmiculatus, 27, 35, 36, 45, 53; Map 35, p. 89.

Ethcostomu cocrulcum, 33, 37, 45, 64: Map 50, p. 96.

Eliteostoma flabellare, 33, 37, 45, 53, 64: Map 51, p. 97.

Etheostomut jessioc, 17, 33.

Ethcostama zonalc, 33, 37, 45, 64, 65 ; Map 49, ए. 96.

European carp, sec Cuprimus carpio.

Fan-tailed darter, see Etheosloma fiabcllare.

Fathead minnow, see Pincthalcs promclas.

Fiddler, see Ictalurus punctatus.

Fine-scaled sucker, sec Catosfomms commucrsonii.

Fundulus notattes, 28, 36, 45, 60; Ma; 36. p. 80 .

Garman's sumfislx, see Lcpomis minialus.

Gilbert's mimow, see Nolrapis yillorti.

Gizzard-shad, see Dorosoma ipolianu?!n.

Golden shmer, see Abramis crusolencas.

Goggle-cye, sce Ambloplites mpestris.

Gonjon. sce Lepteps olizaris.

Grass pilke, sce Fosor ím

Green-sided darter, sec Diplosion blennioidis.

Grcen stunfish, see Lcromis cyancllus.

Jodroptems aspro, 32, 45: Map t4. 1). 93.

IIadropiortes phoraccphalus, 32, 45: Map 45, p. 94.

High-back buffalis, sec lotiobus lubulus. 
Hiodon toryisus, $19,45$.

Hogsucker, see Catostomis miyricans.

Horned dace, see Scmotilus atromacniatus.

Horned pout, see Amciurns melas.

Horned shiner, see Notropis cormutus.

Horny-head, see Hybopsis kcnluckirissis.

Hyboynathas nuchalis, 23, 43, 64, 66, Map 12, 1. 77

Hybopsis amblops, 25, 37, 44, 64: Map 27 . p. 85.

Hybopsis liculuckicusis, 26, 36, 37, 38, 40. 44, 56, 67, 68, 69, 71; Мар 28, p. 85 .

Hybopsis storcrianus, 17, 26.

Ictalurus punctatus, 26, 37, 38, 39, 44; Map 29. 13. 86.

Ictiobus bubalus, 17, 20

lctiobus cyprinclla, 20, 39, 43.

Ictiobus wis, 20, 43.

Johmmy darter, sec Bolcosoma nigrmm.

Kentucky chub, see Hybopsis kcutuckicussis.

Labidestiles sicculus, 28, 45, 53, 60, 64; Mlap 37, p. 90.

Large-mouthed black bass, see Micropterus salmoides.

Lepomis cyancllus, 30, 35, 36, 38, 44, 53, 56: Map 39, p. 91.

lepomis humilis, $30,38,44,53,64$; Map 41. p. 93.

Lepomis megalotis, $30,36,38,44,53$ : Map 40 , p. 91.

Lchomis miniatus, $30,44,53$.

Lcromis pallidus, $30,47,53$.

Leptops olizaris, 17, 27, 44.

Little pickerel, see Eso.t i'crmiculatus.

Log perch, see Pircina caprodes.

Long-eared sunfish, see Lcromis megalotis.

Micropterus dolomicu, 30. 38, 44: Map 42, p. 92.

Micronterus salmoides. 31, 39, 44: Map 43, p. 93.

Minvtrema molanops. 21, 43, 66: Map 5. p. 74.

Nongrel huffalis, see Trliolus urus.

Mnm-eve, see Il indon toruisus.

Morosfoma anisurum, 21.

Mo.rostoma aurcolum, 21, 37, 38, 39, 43: Мар 8, p. 75.

Mo.rostoma hericeps, 21, 38, 39, 43; Maj) 9, p. 76.

Mud-cat, see Leptops olizaris.

Notropis allicrinoides, 25, 43, 64; Map 22. p. 82.

Notropis blemuius. 24, 38, 40, 4.3, 53, 56: Мap 17, p. 80.

Nofropis coluta afrocaudalis, 24, 43.
Intropis curnutus, 25, 36, 37, 38. 41. 43, 56, 60, 6\%, 68, 69, 71; Map 20. p. 81 .

Vofronis yilberti 24, 43, 64, 65; Map 18, ए. 80 .

Netropis illecebrosus, 24, 43, 64, 65.

Nolropis pilshry, 25, 43; Map 21, p. 82.

Notropis umbratilis aprincs, $25,37,40$, $43,53,56,60:$ Map 23, p. 83 .

Notropis ahipplii, 27, 37, 38, 40, 43.53. 56. 60: Мар 19, p. 81.

. Voturus fiazus, 27, 37, 44, 60; Map 32. p. 87.

Opsopocodus cmilioc. 23. 4 .

Orange-spotted sunfish, see Lcpomis lumilis.

Percina caprodes. 32. 37, 45.

Phenacobins mirobilis, 25, 37, H: Map 35, ग. 84 .

Pilshry"s minnow, see Totropis pilsbrvi.

Pimetlales notatus, 23, 34, 35, 36, 37. $38,40,43,47,53,56$ : Мap 14. p. 78.

Pimcphales promilas, 23, 43, 64, 65: Map 13, p. 78.

Pirate-perch, see A plucdederus suvanus.

Pomoris ammularis, 29. 38, 44.

Pomoris sparnides, 29, 39, 44.

Quillback, see Carpiodes a'clifer.

Rainbow darter, see lithostomu cocrulothin.

Red-mouth buffalo. see lotinlus cyprinclla.

Red-tail, see Mo.rostoma braticeps.

Rock bass, see -fmbloplites rupestris.

Round buffialn, see ictiobus mrust.

Sand darter, see tmmocryplo pellatide.

Schillonder crilis. 2T, 47.

Schilhedes oprinus. 27, 44. 64: Mlap 33, p. 88 .

Schilbcodes minrus, 27. H4, 64, 05: Map 34, p. 88 .

Semotilus atremerculesties, 25, 34, 35, 36, 37, 40, 44, 47, 48, 53, 56, 65: Мap 26. p. 84.

Sharp-nosed darter, see Ihadroptirus phovocephalus.

Sheepshead, see thodinotus grmmicni.

Shiner. see . Iotmonis atherinoides.

Short-healed red-horse. see IVorosioma brevichs.

Silver cluwb, sce llylonpsis amblops.

Silver carp. see Corpindes evlifer.

Silverfus. sec. Vopropis ahisplii.

Silver-inoutlyed minnow. see Fricymba blicialus.

Silvery minnow, see Hyognsthus nuchalis.

Slender stonecat. see Sitrilbudes crilis. Small-mouthed black hass, see .Micropic"nss dolomicus. 
Small-mouth buffalo, see Ictiobns bubalus.

Sulub-nosed ninnow, see Opsopocodus cmiliac.

Spotted sucker, sce Minytrena melanops.

Steel-colored minnow, see Notropis whipplii.

Stonecat, see Noturus faous.

Stone-roller, see Catastomus migricans.

Storer's chub, see Hybopsis storcrianus.

Straw-colored minnow, see Notropis blennius.

Striped sucker, see Minytreina melanops.

Sucker, see Catostomus commersonii.
Sucker-mouthed minnow, see Phonacobius mirabilis.

Sweet sucker, see Erimyzon succtta oblongus.

Tadpole cat, see Schilbcodes gyrinus.

Tootled herring, see Hiodon tergisus.

Top-minnow, see Fundulus notatus.

Warmouth bass, see Chacnobryttus gulosus.

White crappie, see Ponoxis amuluris.

White-nosed sucker, see Moxostoma anisurum.

White perch, see Aplodinotus grmmicns.

White sucker, see Morastoma aurealnm.

Yellow bullhead, see Amcinrus natalis.

Yellow cat. see Leptaps olizaris. 